KARINA SCARAMUZZI

\title{
EFEITO ADJUVANTE DA SÍLICA MESOPOROSA NANOESTRUTURADA SBA-15 NA IMUNIZAÇÃO PELA VIA ORAL
}

Dissertação apresentada ao Departamento de Imunologia do Instituto de Ciências Biomédicas da Universidade de São Paulo, para obtenção do Título de Mestre em Ciências.

São Paulo 
KARINA SCARAMUZZI

\section{EFEITO ADJUVANTE DA SÍLICA MESOPOROSA \\ NANOESTRUTURADA SBA-15 NA IMUNIZAÇÃO}

PELA VIA ORAL

Dissertação apresentada ao Departamento de Imunologia do Instituto de Ciências Biomédicas da Universidade de São Paulo, para obtenção do Título de Mestre em Ciências.

Área de concentração: Imunologia

Orientador: Prof. Dr. Osvaldo Augusto Sant'Anna

São Paulo 
DADOS DE CATALOGAÇÃO NA PUBLICAÇÃO (CIP)

Serviço de Biblioteca e Informação Biomédica do

Instituto de Ciências Biomédicas da Universidade de São Paulo

C reprodução total

\section{Scaramuzzi, Karina.}

Efeito adjuvante da sílica mesoporosa nanoestruturada SBA-15 na imunização pela via oral / Karina Scaramuzzi. -- São Paulo, 2009.

Orientador: Osvaldo Augusto Brazil Esteves Sant Anna.

Dissertação (Mestrado) - Universidade de São Paulo. Instituto de Ciências Biomédicas. Departamento de Imunologia. Área de concentração: Imunologia. Linha de pesquisa: Imunização oral e adjuvantes.

Versão do título para o inglês: The adjuvant effect of the mesoporous nanostructurated SBA-15 silica in immunizations by the oral route.

Descritores: 1. Imunização oral 2. Adjuvantes 3. Inflamação 4. Nanopartículas 5. Vacinas 6. Anticorpos I. Sant Anna, Osvaldo Augusto Brazil Esteves II. Universidade de São Paulo. Instituto de Ciências Biomédicas. Programa de Pós-Graduação em Imunologia III. Título. 
Candidato(a):

Título da Dissertação:

Orientador(a):
Karina Scaramuzzi.

Efeito adjuvante da sílica mesoporosa nanoestruturada SBA-15 na imunização pela via oral.

Osvaldo Augusto Brazil Esteves Sant Anna.

A Comissão Julgadora dos trabalhos de Defesa da Dissertação de Mestrado, em sessão pública realizada a .............. ..........
( ) Aprovado(a)
( ) Reprovado(a)

Examinador(a): Assinatura:

Nome:

Instituição:

Examinador(a): Assinatura:

Nome:

Instituição:

Presidente: Assinatura:

Nome:

Instituição: 
Aos meus pais Walter e Isilda, a minha irmã Mariana e ao Rodrigo por todo apoio, por toda confiança, por tanto amor! 


\section{AGRADECIMENTOS}

Ao meu orientador Prof. Dr. Osvaldo Augusto Sant'Anna pela confiança no meu trabalho e por me guiar de forma tão bela durante esses anos de aprendizado. Muito obrigada por tudo!

A Dra. Denise Vilarinho Tambourgi, que contribuiu em todos os momentos para o desenvolvimento do meu projeto e permitiu que eu o realizasse no Laboratório de Imunoquímica do Instituto Butantan.

Ao Dr. Orlando Garcia Ribeiro do Laboratório de Imunogenética do Instituto Butantan pelo fornecimento dos camundongos das linhagens AIR $_{M A X}$ e AIR $_{\text {MIN }}$ e pela ajuda fundamental na realização de muitos experimentos.

As Dras. Solange Barros Carbonare e Milene Tino de Franco do Laboratório de Imunogenética do Instituto Butantan pelas preciosas sugestões e apoio constante.

A Dra. Eliana Faquim de Lima Mauro do Laboratório de Imunopatologia do Instituto Butantan, Dra. Mônica Spadafora Ferreira e Dr. Jorge Mario da Costa Ferreira Júnior do Laboratório de Imunoquímica do Instituto Butantan pelo auxílio imprescindível para o desenvolvimento da minha pesquisa.

Aos Drs. Jivaldo R. Matos do Instituto de Química da Universidade de São Paulo e Márcia C. A. Fantini do Laboratório de Cristalografia do Instituto de Física da USP pelo fornecimento da sílica mesoporosa SBA-15.

Aos técnicos do biotério Edson Luiz da Silva e Severino Ramos da Silva por cuidarem tão bem dos meus camundongos.

Ao funcionário do Laboratório de Imunogenética Ronaldo Antônio Matheus pelas lindas lâminas apresentadas nessa dissertação.

Aos professores, pesquisadores, funcionários e colegas do Instituto Butantan, do Departamento de Imunologia do ICB-USP e, principalmente, do Laboratório de Imunoquímica pelo carinho, amizade e pela convivência agradável.

A Luciana Vieira Carvalho e Estevam José Baldon pela amizade, apoio e incentivo diário.

A amiga Eliana Blini Marengo por estar sempre ao meu lado e pela torcida positiva em todos os momentos.

A Cinthya Kimori Okamoto, Elaine Rodrigues, Gabriela Dicieri Tanaka e Isadora Maria Vilas Boas por tornarem meu dia-a-dia dentro e fora do Laboratório mais agradável.

A Lidiane Zito Grund, Mara Adriana Corrêa e Tatiane Canhamero Gasparelo por todo apoio, companheirismo e amizade. Sem vocês tudo seria muito mais difícil! 
A minha avó Hilda de Almeida Morais por me mostrar minha verdadeira vocação, mesmo que pelo caminho mais tortuoso. Obrigada por estar sempre por perto!

Ao Conselho Nacional de Desenvolvimento Científico e Tecnológico (CNPq) e a Fundação de Amparo à Pesquisa do Estado de São Paulo (FAPESP) pelo apoio financeiro.

Ao Laboratório Cristália pelo apoio financeiro e pela parceria fundamental para o desenvolvimento desse estudo. 
Esse trabalho foi realizado no Laboratório de Imunoquímica do Instituto Butantan, pelo Programa de Pós-graduação em Imunologia do Instituto de Ciências Biomédicas da Universidade de São Paulo.

Apoio Financeiro: CNPq, FAPESP e Laboratório Cristália 


\section{Certificado}

Certificamos que o protocolo registrado sob $\mathrm{n}^{\circ} 041$ nas fls, 45 do livro 2 para uso de animais em experimentação, sob a responsabilidade de Osvaldo Augusto B. E.Sant'Anna Coordenador(a) da Linha de pesquisa "Resposta inflamatória resultante da aplicação da sílica nanoestruturada SBA-15 como adjunvante" do qual participou(aram) o(s) alunos Karina Scaramuzzi e o pesquisador Orlando Garcia Ribeiro Filho, está de acordo com os Princípios Éticos de Experimentação Animal adotado pelo Colégio Brasileiro de Experimentação Animal (COBEA) e foi aprovado pela COMISSÃO DE ÉTICA EM EXPERIMENTAÇÃO ANIMAL (CEEA) em 17.04.2007.

São Paulo, 17 de abril de 2007.
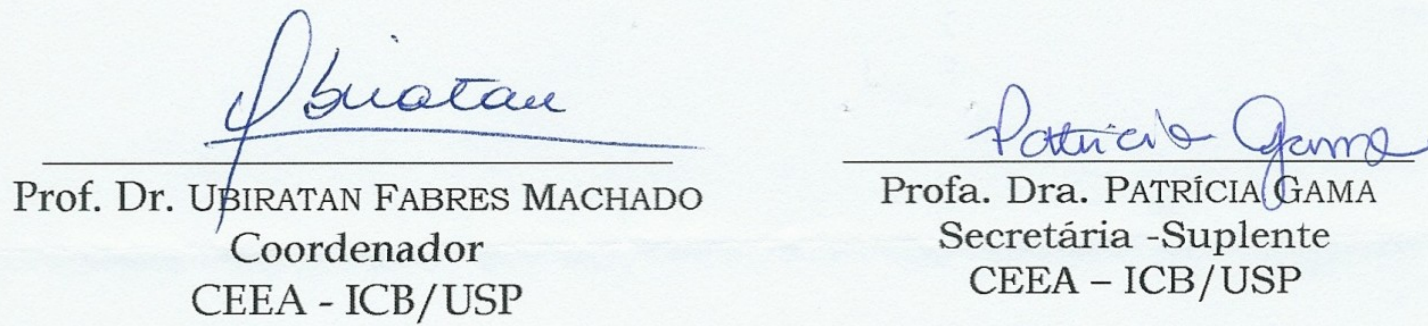


\section{CERTIFICADO}

Certificamos que o Projeto intitulado "Resposta inflamatória resultante da aplicação da sílica nanoestruturada SBA-15 como adjuvante", protocolo $\mathrm{n}^{\circ}$ 375/07, sob a responsabilidade de Osvaldo Augusto Sant'Anna e Karina Scaramuzzi, está de acordo com os Princípios Éticos na Experimentação Animal adotado pelo Colégio Brasileiro de Experimentação Animal (COBEA), e foi aprovado pela COMISSÃO DE ÉTICA NO USO DE ANIMAIS DO INSTITUTO BUTANTAN (CEUAIB) em reunião de 13/03/2007.

"We certify that the Research entitled Inflammatory response obtained of nanostructured SBA-15 silica application as adjuvant, protocol $\mathrm{n}^{\circ} 375 / 07$, under the responsibility of Osvaldo Augusto Sant'Anna and Karina Scaramuzzi, is in agreement with the Ethical Principles in Animal Research, adopted by the Brazilian College of Animal Experimentation, and was approved by the ETHICAL COMMITTEE FOR ANIMAL RESEARCH of BUTANTAN INSTITUTE in the meeting of $\underline{03 / 13 / 2007 " .}$

São Paulo, 16 de março de 2007.

De acordo:

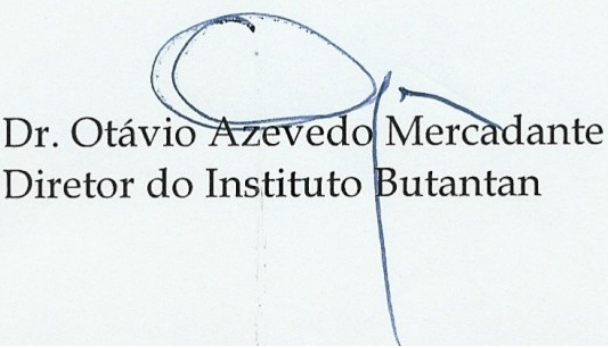

Dr. Otávio Azevedo Mercadante

Diretor do Instituto Butantan 


\section{RESUMO}

SCARAMUZZI, K. Efeito adjuvante da sílica mesoporosa nanoestruturada SBA15 na imunização pela via oral. 2009. $74 \mathrm{f}$. Tese Mestrado (Imunologia) - Instituto de Ciências Biomédicas, São Paulo, 2009.

A sílica nanoestruturada SBA-15 é um polímero que devido à suas propriedades físico-químicas apresenta grande potencial como adjuvante de mucosas. A imunização pela via oral de camundongos com a vacina contra Hepatite A ou gama globulina humana adsorvida a SBA-15 revelou aumento nos títulos de anticorpos específicos lgG e IgA, comprovando que a sílica não interfere na polarização da resposta imunológica dos tipos $T_{H} 1$ ou $T_{H} 2$. Ensaios por citometria de fluxo indicaram que a SBA-15 atuou no recrutamento de fagócitos e no aumento dos números de linfócitos $B$ e $T$ nas placas de Peyer e linfonodos mesentéricos de animais imunizados, sugerindo a proliferação de células imunocompetentes. A administração subcutânea de SBA-15 em camundongos geneticamente selecionados para máxima $\left(\mathrm{AIR}_{\mathrm{MAX}}\right)$ ou mínima $\left(\mathrm{AIR}_{\mathrm{MIN}}\right)$ resposta inflamatória aguda confirmou o baixo potencial inflamatório e a não toxicidade dessa nanopartícula. Os resultados comprovam que a SBA-15 é um adjuvante seguro e eficiente, especialmente nas imunizações pela via oral.

Palavras-chave: Imunização oral. Inflamação. Adjuvantes. Nanopartículas. 


\begin{abstract}
SCARAMUZZI, K. The adjuvant effect of the mesoporous nanostructurated SBA-15 silica in immunizations by the oral route. 2009. 74 p. Master thesis (Immunology) - Instituto de Ciências Biomédicas, São Paulo, 2009.

The nanostructured SBA-15 silica is a polymer that due to its physicochemical properties shows great potential as a mucosal adjuvant. Immunization by the oral route of mice with Hepatitis A vaccine or human gama globulin adsorbed in SBA-15 revealed increases in IgG and IgA specific antibody titers and showed that this silica does not interfere in the polarization of $\mathrm{T}_{\mathrm{H}} 1$ or $\mathrm{T}_{\mathrm{H}} 2$ immune responses. Flow cytometry assays demonstrated that SBA-15 was efficient in the recruitment of phagocytes and in increasing the numbers of B and T lymphocytes in Peyer's patches and mesenteric lymph nodes of immunized mice, promoting the proliferation of immunocompetent cells. Subcutaneous administration of SBA-15 in genetically selected mice for high $\left(A I R_{M A X}\right)$ or low $\left(A I R_{M I N}\right)$ acute inflammatory responses indicated the low inflammatory potential and the non-toxicity of this nanoparticle. Results ascertain that SBA-15 silica is an effective and safe adjuvant especially in immunizations by the oral route.
\end{abstract}

Keywords: Oral immunization. Inflammation. Adjuvants. Nanoparticles. 
1 INTRODUÇÃO

1.1 Reação inflamatória e desenvolvimento da resposta imune ..................... 14

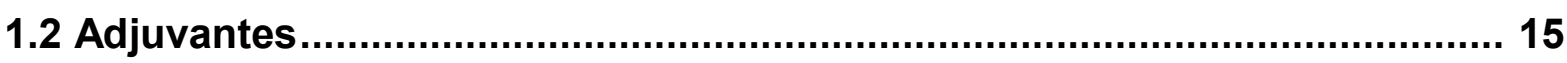

1.2.1 Sílicas mesoporosas altamente ordenadas ............................................ 17

1.3 Administração de vacinas pela via oral .................................................... 18

1.4 Tecido linfóide associado ao trato gastrointestinal (GALT) ...................... 19

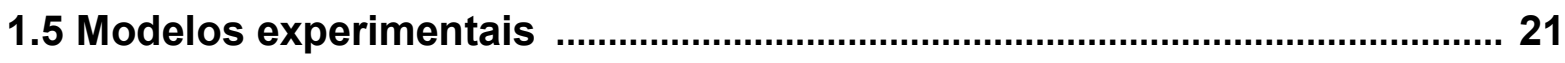

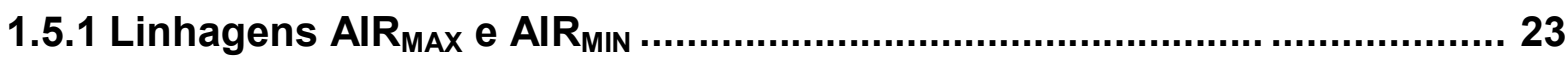

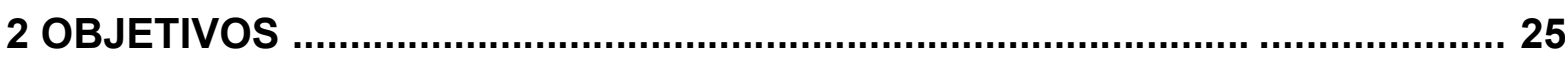

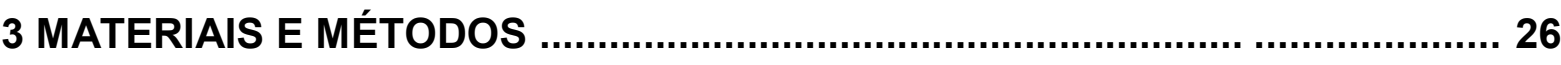

3.1 Potencial de encapsulação/adsorção da gama globulina humana a

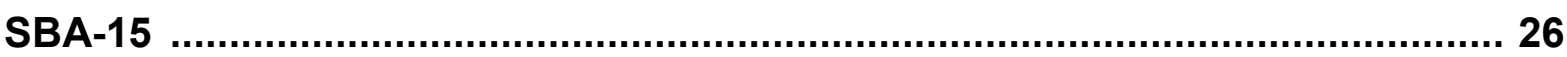

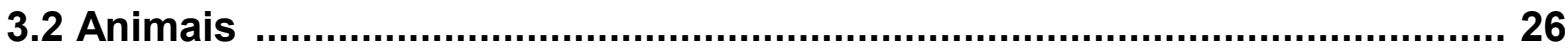

3.3 Sílicas mesoporosas altamente ordenadas .......................................... 27

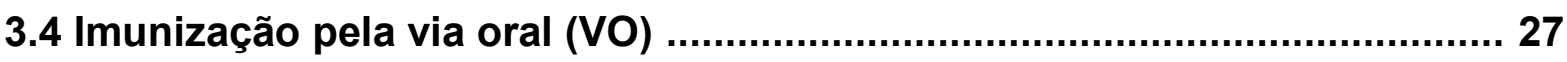

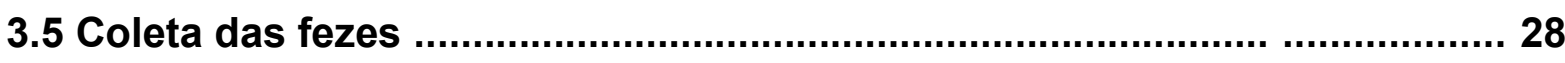

3.6 Determinação dos títulos de anticorpos $\lg A$ e $\lg G$ anti-Hepatite $A$ e antigama globulina humana por ELISA ........................................................... 28

3.7 Análise morfológica e histológica das placas de Peyer ........................... 29

3.8 Imunofenotipagem das células das placas de Peyer e linfonodos

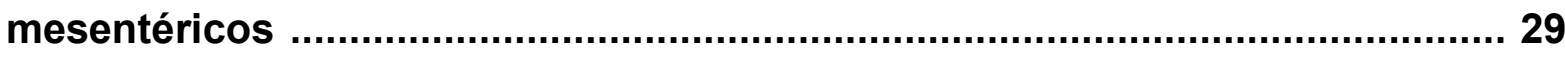

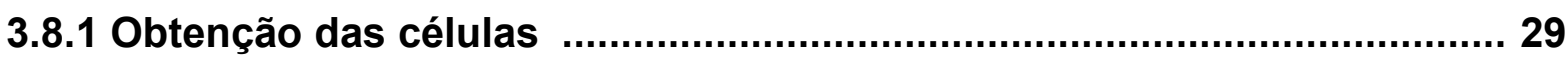

3.8.2 Análises por citometria de fluxo ...................................................... 30

3.9 Indução da reação inflamatória e caracterização dos tipos celulares ....... 31

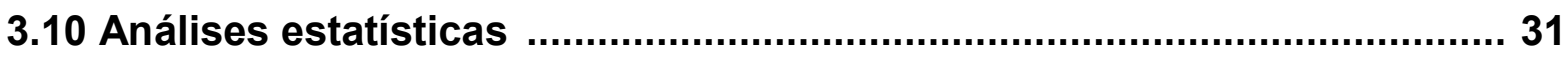

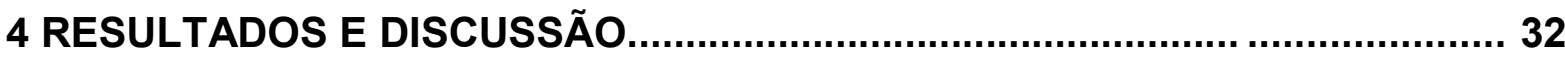

4.1 Análise do potencial de encapsulação/adsorção da gama globulina humana a sílica nanoestruturada SBA-15 .................................................... 32

4.2 Estudo do potencial adjuvante da sílica nanoestruturada SBA-15 em imunizações pela via oral 
4.2.1 Efeito da SBA-15 na produção de anticorpos IgA secretada (s-IgA) em imunizações com vacina contra Hepatite A pela via oral

4.2.2 Efeito da SBA-15 na produção de anticorpos séricos e secretados em imunizações com gama globulina humana pela via oral

4.2.2.1 Efeito dose-resposta e padronização da imunização com gama

globulina humana 35

4.2.2.2 Análise da produção de anticorpos séricos e secretados das classes IgA e IgG anti-HGG após imunização com a sílica SBA-15 36

4.3 Efeito da SBA-15 na morfologia das placas de Peyer 40

4.4 Análises imunofenotípicas das células das placas de Peyer e linfonodos mesentéricos por citometria de fluxo após imunização pela via oral utilizando a sílica nanoestruturada SBA-15 como adjuvante 43

4.4.1 Imunofenotipagem das células das placas de Peyer 43

4.4.1.1 Imunização com vacina contra Hepatite A 43

4.4.1.2 Imunização com gama globulina humana 47

4.4.2 Imunofenotipagem das células dos linfonodos mesentéricos 52

4.4.2.1 Imunização com gama globulina humana 52

4.5 Reação inflamatória aguda induzida após administração subcutânea da sílica SBA-15

4.5.1 Perfil celular do exsudato inflamatório 57

4.6 Análise comparativa da resposta inflamatória aguda induzida pela

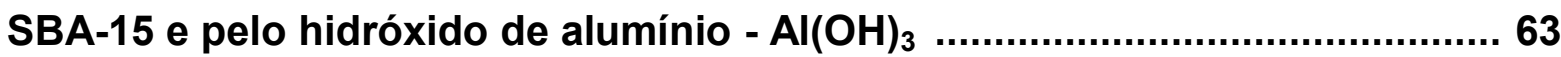

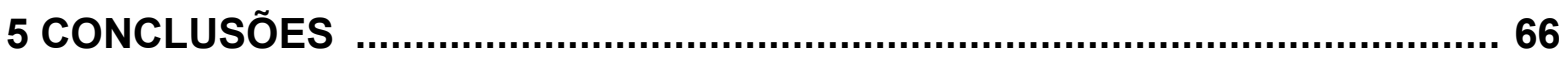

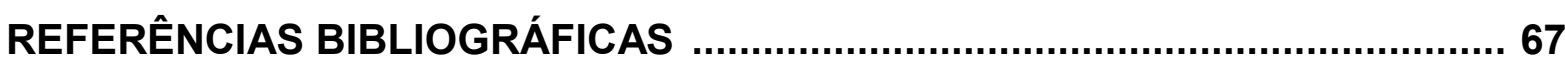




\section{INTRODUÇÃO}

\subsection{Reação inflamatória e desenvolvimento da resposta imune}

O processo inflamatório é fundamental para o início da resposta imunológica atuando como elo entre a imunidade inata e adquirida; nesse período observa-se o aumento da produção de células pela medula óssea que leva ao acúmulo e à ativação de fagócitos que contribuem diretamente para a eliminação de patógenos e/ou injúria. Sinais diretos (moleculares) e indiretos (injúria tecidual e/ou infecção) mantêm a resposta inflamatória por ativação de células epiteliais e endoteliais, mastócitos, macrófagos, plaquetas e neutrófilos, estimulando o influxo de polimorfonucleares (PMN) e de células apresentadoras de antígenos (APC) para o foco inflamatório. Produtos bacterianos, células em necrose, citocinas e a ligação CD40/CD40L ativam as APC e, conseqüentemente, aumentam a expressão de moléculas estimuladoras e a produção de citocinas primordiais na ativação dos linfócitos T e desenvolvimento da imunidade adquirida (NATHAN, 2006).

A resposta imune adquirida engloba as fases iniciais de contato com o imunógeno e ativação de linfócitos e a fase efetora que culmina na eliminação antigênica e retorno à homeostasia do sistema imune.

Linfócitos $B$, precursores de plasmócitos secretores de anticorpos, podem responder a antígenos, como polissacarídeos e lipopolissacarídeos, de maneira Tindependente a partir da ligação direta às imunoglobulinas expressas na sua superfície, levando a uma rápida resposta de anticorpos; ou de modo dependente de linfócitos $T$ auxiliares $\left(T_{H}\right)$ através da interação CD40/CD40L e da influência de citocinas (VOS et al., 2000).

Através dos seus receptores (TCR), os linfócitos $T$ reconhecem antígenos processados e ligados às moléculas codificadas pelos genes do Complexo Principal de Histocompatibilidade (MHC), expressas nas superfícies celulares. As moléculas de MHC classes I e II associadas a peptídeos antigênicos estimulam, através da interação com os co-receptores CD8 e CD4, linfócitos T citotóxicos (CTL) e T auxiliares $\left(T_{H}\right)$, respectivamente. Após ativação, expansão clonal e diferenciação, os linfócitos $T$ assumem funções efetoras diferenciadas dependendo dos estímulos que recebem e do micro-ambiente em que se encontram (LEBIEN e TEDDER, 2008). 
Linfócitos $T$ citotóxicos contribuem principalmente para a eliminação de patógenos intracelulares e células tumorais, enquanto linfócitos $T$ auxiliares atuam na proliferação e diferenciação de linfócitos $B$ e $T$, macrófagos e células dendríticas. Linfócitos $T_{H}$ dividem-se em células do tipo $T_{H} 1$, responsáveis pela proteção contra patógenos intracelulares caracterizada pela expressão de interferon- $\gamma$ (IFN- $\gamma$ ), reações de hipersensibilidade do tipo tardia e doenças autoimunes; linfócitos $T_{H} 2$ participam de doenças alérgicas e da proteção contra patógenos extracelulares, exotoxinas bacterianas e helmintos, desenvolvendo uma resposta mediada por anticorpos e expressão de citocinas como IL-3, IL-4, IL-5, IL-10 e IL-13; linfócitos $T_{H} 3$, responsáveis pela secreção de TGF- $\beta$ e pela regulação da resposta imune ao nível das mucosas; a subpopulação $T_{H} 17$, que secreta a citocina pró-inflamatória IL17, atua na proteção contra patógenos extracelulares e fungos, além de interceder em processos autoimunes; e os $T$ reguladores $\left(T_{R E G}\right)$ que apresentam função supressora controlando doenças autoimunes, alergias, infecções e câncer (FARIA e WEINER, 2005; COFFMAN, 2006; ROMAGNANI, 2006; AFZALI et al., 2007; OUKKA, 2008; AKDIS, 2009; HOGQUIST e MORAN, 2009).

$A$ defesa contra infecções não se deve apenas à ativação de linfócitos $B$ e $T$ antígeno-específicos, mas também à estimulação da resposta imune inata. $\mathrm{O}$ uso de adjuvantes nos processos de vacinação, método mais eficiente na proteção contra patógenos, pode gerar reação inflamatória local e levar ao desenvolvimento da resposta imune adquirida. Os processos imunológicos desencadeados pela imunidade adquirida permitem a troca de classes de imunoglobulinas, maturação de afinidade dos anticorpos e a formação de memória imunológica, fundamental na proteção do organismo contra exposições subseqüentes ao mesmo antígeno (FOGED et al., 2002; JONSDOTTIR et al., 2008).

\subsection{Adjuvantes}

Adjuvantes, do latim adjuvare (ajudar a), são compostos que potencializam a imunogenicidade de um dado antígeno amplificando e/ou melhorando a duração da resposta imune especifica (EDELMAN e TACKET, 1990). Uma das primeiras descrições de substâncias com potencial adjuvante ocorreu em 1916; Le Moignic e Pinoy imunizaram camundongos com uma emulsão de água, vaselina e Salmonella typhimurium inativada e verificaram o aumento da resposta imune específica contra 
o microorganismo (JANSEN et al., 2005 apud PINOY e LE MOIGNIC, 1916). Entre os adjuvantes já descritos encontram-se as emulsões de água em óleo, surfactantes naturais e sintéticos, géis minerais e produtos bacterianos (BREWER, 2006).

A utilização dos adjuvantes resulta na modulação da resposta imune adquirida, alterando os padrões de citocinas que a regulam, aumentando ou facilitando a apresentação de epítopos a células efetoras do sistema imunológico, influenciando a magnitude da resposta e a produção de isótipos de imunoglobulinas, além de preservar a integridade do imunógeno, prolongando o período de estímulo e o tempo de apresentação antigênica (COX e COULTER, 1997; BANCHEREAU e STEINMAN, 1998; SCHIJNS e DEGEN, 2007).

Atualmente, entre os adjuvantes licenciados para uso em humanos, encontram-se os derivados de hidróxido e fosfato de alumínio que compõem quimicamente a maioria das vacinas bacterianas e virais para as quais a proteção relaciona-se à geração de anticorpos neutralizantes. Os mecanismos de ação desses adjuvantes incluem a liberação lenta do imunógeno, indução de inflamação e conseqüente recrutamento e ativação de APC e a conversão de antígenos solúveis para a forma particulada, facilitando a fagocitose por macrófagos, células dendríticas e linfócitos B (LAMBRECHT et al., 2009). Entretanto, o hidróxido de alumínio não induz resposta imunológica elevada, além de direcionar a resposta para a imunidade do tipo $\mathrm{T}_{\mathrm{H}} 2$ com estímulo predominante à produção de citocinas como IL-4 e IL-5. Ainda, gera baixa resposta imune mediada por células (CMI), incluindo a resposta de linfócitos $T$ citotóxicos (CTL); ressalte-se que a polarização da resposta não é adequada para a proteção contra determinadas infecções e para vacinas em desenvolvimento contra AIDS, tuberculose e malária que, a princípio, requerem predominantemente resposta imune do tipo $\mathrm{T}_{\mathrm{H}} 1$. Os Adjuvantes Incompleto (AIF) e Completo de Freund (ACF) são eficientes na geração de resposta do tipo $T_{H} 1$, entretanto, provocam forte reação inflamatória local, com formação de granuloma e necrose tecidual.

Assim, há interesse crescente de investigar estratégias de imunização e desenvolvimento de adjuvantes que, de um lado não interfiram na polarização da resposta imunológica, e por outro sejam seguros, economicamente viáveis e que possibilitem a melhoria da resposta em indivíduos constitutivamente maus respondedores (COX e COULTER, 1997; BREWER, 2006). 


\subsubsection{Sílicas mesoporosas altamente ordenadas}

As sílicas mesoporosas são partículas de óxido de silício $\left(\mathrm{SiO}_{2}\right)$ com estrutura altamente organizada que, devido às suas propriedades físico-químicas, apresentam potencial de aplicação em diferentes áreas, e que vêm despertando grande interesse da comunidade científica. Esses materiais são capazes de interagir com átomos, íons e moléculas, não apenas em sua superfície, como também em seu interior (KRESGE et al., 1992; YANG et al., 1997).

Descrita em 1998, a sílica mesoporosa SBA-15 apresenta estrutura hexagonal com poros $(3,1-6,4 \mathrm{~nm})$ altamente ordenados e interligados, paredes relativamente espessas e notável estabilidade térmica, hidrotérmica e mecânica (Figura 1) (ZHAO et al., 1998; MATOS et al., 2001). A SBA-15 é sintetizada em meio ácido, utilizando como agente direcionador de estrutura um copolímero tribloco, o poli(óxido de etileno)-poli(óxido de propileno)-poli(óxido de etileno) $\left(\mathrm{EO}_{20} \mathrm{PO}_{70} \mathrm{EO}_{20}\right.$ ), que pode auto agregar-se com espécies de silicatos formando a sílica mesoporosa (ZHAO et al., 1998).

Apesar dos vários estudos voltados para a utilização de sílicas como veículo para diferentes substâncias, essas não haviam sido testadas quanto à capacidade de ativar eficientemente as APC, carrear e liberar imunógenos.

O primeiro estudo sobre a viabilidade de emprego desse material nanoestruturado como adjuvante da imunidade realizou-se no Laboratório de Imunoquímica do Instituto Butantan, empregando-se a sílica mesoporosa SBA-15. Verificou-se que camundongos isogênicos BALB/c e geneticamente selecionados para a baixa produção de anticorpos $\left(L_{\text {III }}\right)$ imunizados com Intimina $1 \beta$ (proteína de E. coli) ou veneno total da serpente Micrurus ibiboboca encapsulado/adsorvido a SBA-15 apresentaram aumento significativo dos títulos de anticorpos específicos para a proteína e para o veneno da serpente, sendo a resposta secundária semelhante ou mais elevada comparativamente aos animais imunizados com esses imunógenos em AIF ou $\mathrm{Al}(\mathrm{OH})_{3}$ (MERCURI et al., 2006). Ainda, verificou-se que a sílica SBA-15 foi capaz de modular positivamente a resposta imune humoral de camundongos maus respondedores ( $L_{\| l l}$; $\left.L_{I V A}\right)$, os quais após imunizações com soro albumina bovina (BSA) pelas vias oral e intramuscular passaram a produzir títulos de IgG semelhantes aos bons respondedores ( $\left.\mathrm{H}_{\| I I} ; H_{I V A}\right)($ CARVALHO, 2007). Esses dados em conjunto indicam a participação da SBA-15 na ativação do sistema 
imunológico e na indução de memória, mecanismo essencial para a proteção induzida por processos de vacinação.

Em 12 de setembro de 2005 foi depositada a Patente COMPLEXO IMUNOGÊNICO FORMADO POR ANTÍGENOS VACINAIS ENCAPSULADOS POR SÍLICA MESOPOROSA NANOESTRUTURADA, em parceria com o Laboratório Cristália, que recebeu o número PI 0503817-0 e, em setembro de 2007, foi encaminhado seu depósito internacional.

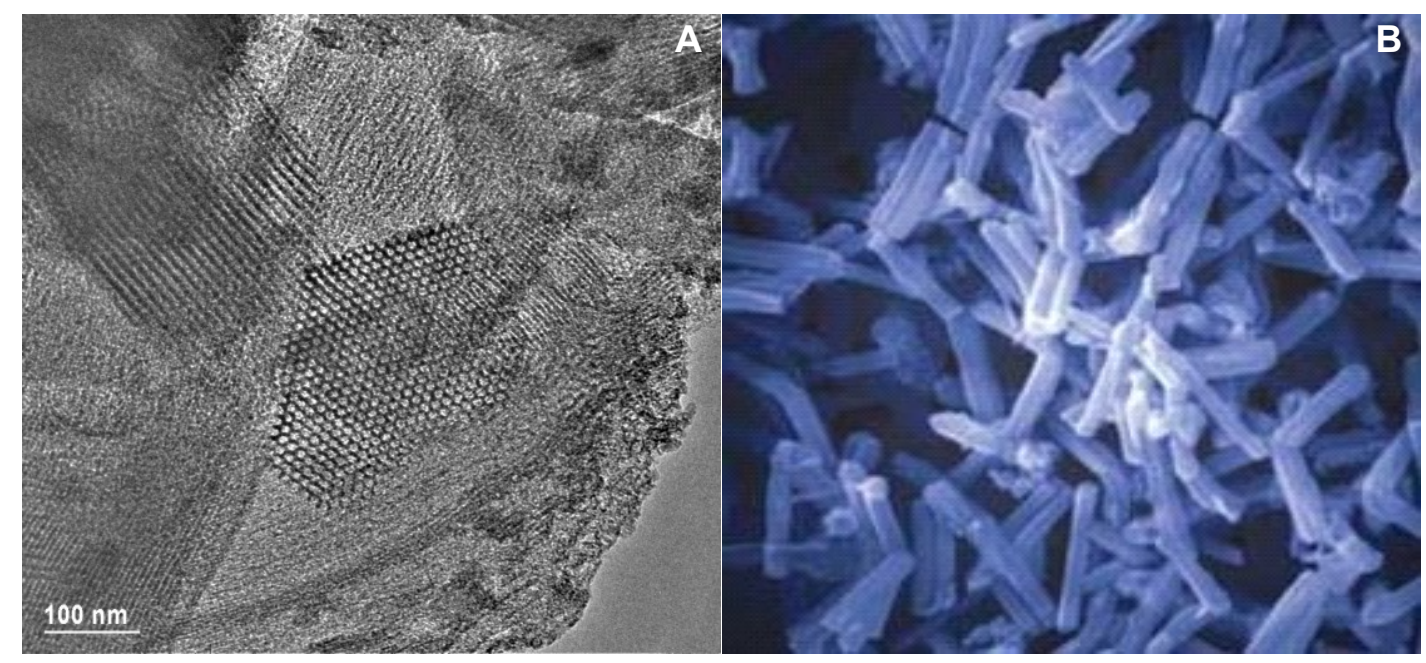

Figura 1- Microscopia eletrônica de transmissão (TEM) da sílica mesoporosa nanoestruturada SBA-15. (A) Estrutura de poros arranjados hexagonalmente. (B) Interior dos poros interconectados. Tamanho médio da partícula: $30 \mu \mathrm{m}$. Tamanho dos poros: 3,1 - 6,4 nm (Laboratório Nacional de Luz Síncrotron LNLS).

\subsection{Administração de vacinas pela via oral}

O método de imunização mais conveniente no âmbito sócio-econômico é a vacinação oral. A facilidade de aplicação, o fato de ser pouco invasiva e de apresentar reduzidos efeitos colaterais, como os comumente observados após imunizações parenterais, são algumas das suas vantagens frente a outras vias de inoculação. Inicialmente acreditava-se que a geração da imunidade de mucosas ocorria através de imunização tópica, contudo vacinas intramusculares ou subcutâneas induzem baixa proteção ao organismo comparando-se às imunizações pelas vias nasal ou oral, especialmente quando a porta de entrada do agente infeccioso é o trato gastrointestinal. São poucas as vacinas licenciadas para a 
aplicação oral, entre elas estão as vacinas contra a poliomielite e rotavírus, ambas contém os vírus atenuados e apresentam alta imunogenicidade (CERUTTI, 2008).

Entretanto, existem limitações para a imunização oral, como as alterações causadas nos epítopos durante o tráfego pelo trato gastrointestinal, e variações no tempo de exposição e captura dos mesmos. Fatores ambientais como a acidez elevada e a ação de proteases podem levar a alterações e denaturações dos epítopos, com subseqüente precipitação do antígeno na luz intestinal, diminuição da afinidade com a superfície das células $M$ e ocupação das placas de Peyer por peptídeos-epítopos inativos, prejudicando o desenvolvimento da resposta imunológica. Ainda, as imunizações pela via oral são eficientes por um curto período, sendo necessárias várias doses para estimular e manter a resposta imune. Obviamente, há possibilidade de indução de tolerância dependendo das concentrações, das doses administradas, dos intervalos entre imunizações e do uso de adjuvantes (SHALABY, 1995; CERUTTI, 2008).

Nesse contexto, o desenvolvimento de vacinas administradas pela via oral visa facilitar a captura dos antígenos pelas células $M$, aumentar a capacidade fagocítica das APC, modular a proliferação de linfócitos B e T antígeno-específicos e proteger 0 antígeno contra a degradação enzimática, aumentando sua imunogenicidade e garantindo imunidade prolongada e sistêmica (SHALABY, 1995).

\subsection{Tecido linfóide associado ao trato gastrointestinal (GALT)}

O trato gastrointestinal dos mamíferos apresenta barreiras morfológicas e fisiológicas que limitam a digestão e absorção, criando um ambiente seletivo entre o meio externo e a circulação sistêmica. A estrutura gastrointestinal é similar do estômago ao ânus, constituída por epitélio cilíndrico simples e células especializadas na secreção de muco e captura de antígenos. Quantitativamente, o intestino é o órgão efetor mais importante da imunidade humoral, mostrando-se responsável por cerca de $80 \%$ da produção total de imunoglobulinas, sendo que desse total, 80 a $90 \%$ pertencem à classe $\operatorname{lgA}$, imunoglobulinas geradas principalmente por plasmócitos presentes nas placas de Peyer, aglomerados de nódulos linfóides bem definidos localizados ao longo do intestino delgado, e linfonodos mesentéricos (JEPSON et al., 1996; SMITH et al., 1998; BRANDTZAEG et al., 1999; KELSALL e JOHANSSON, 2005). 
Locais importantes na indução da imunidade de mucosas compõem o tecido linfóide associado ao trato gastrointestinal - GALT (Gut-associated lymphoid tissues) - e compreendem estruturas como as placas de Peyer no intestino delgado, folículos linfóides isolados no ceco e apêndice e linfonodos mesentéricos.

Como referido acima, as placas de Peyer são conjuntos de folículos linfóides; acham-se separados da luz intestinal por uma única camada de células do FAE (Follicle Associated Epithelium), atuando principalmente na captura de bactérias e vírus patogênicos. Pouco se sabe sobre a ligação desses microorganismos com as células $M$ encontradas no FAE, portas de entrada para antígenos presentes na luz intestinal, mas acredita-se que a captura ocorra de modo seletivo, baseado nas propriedades físico-químicas das partículas capturadas (SMITH et al., 1998).

A localização das placas de Peyer varia conforme a espécie; em camundongos essas estruturas são maiores e mais numerosas na região distal do intestino delgado ocupando principalmente o íleo. O tamanho pode variar de 1,5 a 3,0 mm de diâmetro dependendo do número de agregados de folículos linfóides. As placas menores são formadas por cerca de 2 folículos, já as maiores chegam a ter até 8 folículos linfóides. Essas placas podem ser observadas logo no início da vida fetal, aproximadamente após a $11^{\text {a }}$ semana de gestação, entretanto, o desenvolvimento do centro germinativo só é observado após o nascimento, o que reflete a dependência do ambiente para a hiperplasia folicular. Assim, essas estruturas aumentam de tamanho e número conforme a idade, atingindo seu ápice na puberdade e decaindo na idade adulta (BRANDTZAEG e JOHANSEN, 2005). Nas placas de Peyer se inicia a resposta imune contra patógenos a fim de que a microbiota local se mantenha e o organismo proteja-se contra infecções. Em seus centros germinativos ocorre a interação entre linfócitos $B$ e T além da mudança de isótipo de imunoglobulinas, síntese e secreção de anticorpos da classe IgA devido ao microambiente rico em citocinas como IL-4, IL-6, IL-10 e TGF- $\beta$ que auxiliam a expansão clonal de plasmócitos produtores desses anticorpos. Ainda, dados recentes indicam que o ácido retinóico (RA) e a enzima óxido nítrico sintase induzida (iNOS) participam da mudança de classe, estimulando a migração de células $B$ e a diferenciação em plasmócitos, aumentando os níveis de IgA secretada. A principal proteção ao indivíduo é oferecida pela $\lg A$ secretada (s-lgA) para a luz intestinal produzida, inclusive, no contexto não inflamatório e independente de linfócitos $T$ (MORA et al., 2006; CERUTTI e RESCIGNO, 2008). 
As células $M$, responsáveis pela captura de antígenos da luz intestinal, permitem o encontro do mesmo com as APC. Esse processo, conhecido por transcitose, é passivo e não resulta na digestão antigênica; apesar de expressarem MHC classe II, não se comprovou a capacidade dessas células de processar e apresentar antígenos (SHALABY, 1995).

As células dendríticas (DC) das mucosas iniciam a resposta imune contra patógenos e controlam a atividade de células $\mathrm{T}$ reguladoras bem como a tolerância oral, participando ativamente na indução, manutenção e regulação negativa das inflamações da mucosa induzidas por alergias e processos crônicos (KELSALL e JOHANSSON, 2005; IWASAKI e KELSALL, 2008). Nas placas de Peyer existem sub-populações distintas de DC, todas apresentam como marcador de superfície o receptor $\mathrm{CD} 11 \mathrm{c}^{\mathrm{HIGH}}$ e mostram-se fundamentais na captura de antígenos protéicos e apresentação antigênica; esses grupos de leucócitos têm meia vida de 3 a 5 dias e são provenientes de precursores independentes.

Os diferentes subtipos de DC apresentam funções bem delimitadas dependendo da sua localização e possibilidade de contato com antígenos e com linfócitos B e T. Duas sub-populações são classicamente identificadas, as DC imaturas e maduras; a primeira delas compreende células eficientes na fagocitose de imunógenos, e localizadas na região do domo sub-epitelial das placas de Peyer. Após o contato com os antígenos, as DC migram para a região inter-folicular das placas, tornando-se maduras e capazes de ativar linfócitos $T$, sendo que essa migração ocorre devido às quimiocinas, em especial a CCR7, expressas na zona de linfócitos T. Na ausência de infecção, as DC produzem citocinas como IL-10 e TGF$\beta$, mantendo o perfil de resposta do tipo $T_{H} 3$ e a supressão de resposta $T_{H} 2$.

Quando de um processo infeccioso, especialmente devido à expressão de antígenos protéicos, o microambiente das mucosas tende a induzir resposta $\mathrm{T}_{\mathrm{H}} 2$ devido à produção predominante de citocinas como IL-4, IL-5 e IL-10 (KELSALL e JOHANSSON, 2005).

\subsection{Modelos experimentais}

Os caracteres quantitativos, que constituem a maioria dos fenótipos das mais diversas espécies, exibem variações contínuas e são controlados por mais de um gene com interações aditivas. Esse tipo de variação deve-se à sobreposição de 
segregações simultâneas dos diferentes genes que determinam a característica, somada à variação também contínua de fatores não genéticos ou ambientais. Assim, quando uma população apresenta distribuição contínua ou unimodal para uma dada característica, sugere-se um controle poligênico do caráter, que está ou não associado a polimorfismo ao nível de um ou mais loci que o regulam. Para as estimativas dos genes envolvidos na regulação de um caráter quantitativo, foram desenvolvidos métodos estatísticos que têm por base: 1 - a segregação independente dos diferentes loci que contribuem para o fenótipo; 2 - a contribuição de cada locus para a característica é equivalente; 3 - existem apenas dois alelos por locus. Saliente-se que esses preceitos são assumidos mas não correspondem ao que ocorre na prática.

As diferenças individuais quantitativas possibilitam a atuação da seleção natural e direcionam seu acúmulo durante a evolução. Assim, o valor adaptativo de uma dada característica tem significância evolutiva ao nível de uma população constituída de indivíduos geneticamente heterogêneos. As observações da acumulação progressiva na escala filogenética da complexidade das estruturas e mecanismos imunológicos são fortemente indicativas de seus valores adaptativos na proteção de populações a patógenos diversos presentes em seus habitats. A gênese dessa conservação poderia ser atribuída à fixação de alelos favoráveis que regulam os mecanismos protetores básicos, o que resultaria na homogeneidade genética dos indivíduos de uma espécie relativamente às funções imunobiológicas. Entretanto, há grande variabilidade fenotípica individual para os principais parâmetros imunológicos. Essa grande diversidade pode resultar de polimorfismo alélico em um locus único (caso dos genes de reconhecimento) ou pode advir do efeito aditivo de alelos relevantes em vários loci, ou ainda da associação de ambos.

Em 1968, Guido Biozzi e colaboradores iniciavam uma linha de pesquisa essencial para a geração de conhecimentos em Imunogenética. Assim, os controles genéticos independentes das principais funções imunobiológicas foram demonstrados através de estudos com linhagens selecionadas para os diferentes segmentos que compõem a imunidade, como a síntese de anticorpos, resposta inflamatória aguda e tolerância imunológica (BIOZZI et al., 1979; IBAÑEZ et al., 1992; DA SILVA et al., 1998).

A caracterização de mecanismos genéticos que atuam na série complexa de fenômenos imunobiológicos, inclui estudos experimentais sobre a regulação 
quantitativa da resposta imune desenvolvidos através de seleções genéticas de linhagens apresentando fenótipos extremos para a característica de interesse. Como mencionado, esses trabalhos iniciaram-se tendo por base a genética da produção quantitativa de anticorpos em resposta a doses ótimas imunizantes de imunógenos naturais com multi-determinantes antigênicos. Nessas condições experimentais, a fase de reconhecimento específico dos vários epítopos é sobrepassada, evidenciando-se a variabilidade do caráter síntese quantitativa de anticorpos, cujo controle se faz poligenicamente. Esse sistema difere substancialmente dos controles genéticos exercidos qualitativa e especificamente pelos genes ligados ao MHC ou dos alótipos e genes de cadeias variáveis das imunoglobulinas.

Assim, a demonstração da regulação poligênica multi-específica da resposta imune se fez através de cruzamentos seletivos bidirecionais, evitando-se a consangüinidade, a partir de populações geneticamente heterogêneas de camundongos cruzados ao acaso, onde o caráter fenotípico considerado foi a produção máxima (Linhagem $\mathrm{H}$ ) ou mínima (Linhagem $L$ ) de anticorpos a imunógenos naturais complexos (BIOZZI et al., 1979).

\subsubsection{Linhagens AIR $_{\text {MAX }}$ e AIR MIN}

O controle poligênico do processo inflamatório agudo foi claramente demonstrado através da seleção de linhagens de camundongos capazes de desenvolver resposta inflamatória máxima $\left(A I R_{M A X}\right)$ ou mínima $\left(A I R_{M I N}\right)$ após estímulo com partículas de poliacrilamida, substância não antigênica. Diferentemente das seleções para produção de anticorpos que teve como população inicial camundongos Swiss cruzados ao acaso, a seleção para resposta inflamatória teve como população de origem os descendentes de cruzamentos entre 8 linhagens isogênicas distintas, fato que possibilita a eventual reprodução da seleção: 


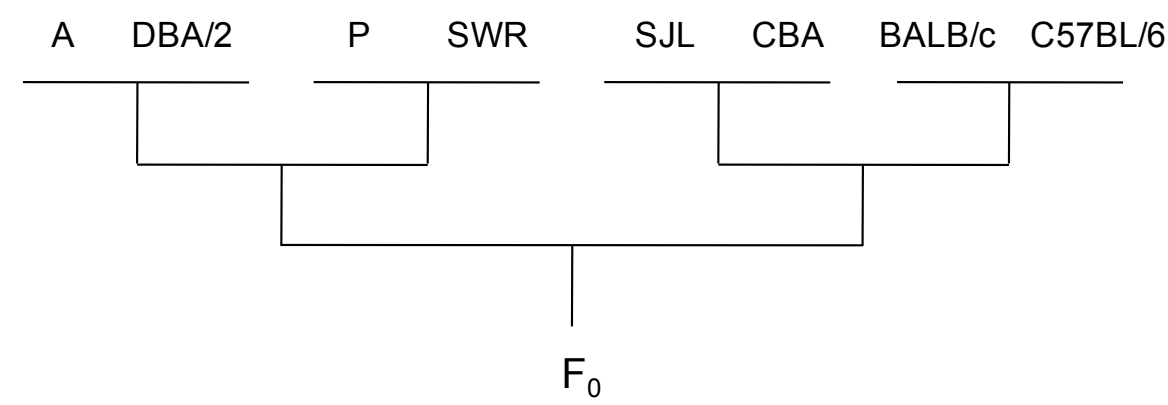

Como ocorreu nos experimentos de seleção para a resposta humoral, houve divergência progressiva interlinhagens $A I R_{\text {MAX }}-A R_{\text {MIN }}$ para os fenótipos analisados número de células e concentração de proteínas no exsudato local inflamatório. Um fenômeno marcante foi a assimetria do processo seletivo; durante 18 gerações, a resposta de seleção foi praticamente nula para a linhagem $A I R_{M I N}$, indicando a importância do valor adaptativo desse fenótipo: para sobreviver é necessário que haja um mínimo de inflamação. Fato relevante é a similaridade das porcentagens de monócitos e a diferença significativa de $P M N$ das linhagens $A I R_{M A X}$ e $A I R_{\text {MIN. }}$. Estima-se que 7 a 11 genes controlem a resposta inflamatória aguda (IBAÑEZ et al., 1992). Após 20 gerações de acasalamentos seletivos, as linhagens atingiram o limite de seleção e os alelos de resposta para o influxo celular e exsudato protéico encontram-se em homozigose nas linhagens $A R_{\text {MAX }}$ e $A I R_{\text {MIN }}$ (BIOZZI et al.,1998; IBAÑEZ et al., 1992).

Estas linhagens divergem também para outros agentes inflamatórios não relacionados entre si ou com o Biogel (agente selecionador), como a carragenina, o zimosan e o veneno de Bothrops jararaca. A resistência e suscetibilidade destas linhagens a doenças tumorais, autoimunidades, infecções e transplantes também sofreram alterações genéticas no decorrer do processo seletivo (VASQUES-BRAVO et al., 1996; CARNEIRO et al., 2002; BIOZZI et al., 1998; MARIA et al., 2003; RIBEIRO et al., 2005; VIGAR et al., 2000; PETERS et al., 2007; ARAÚJO et al., 1998; BORREGO et al., 2006; LAROCCA et al., 2008).

$\mathrm{O}$ uso das linhagens geneticamente selecionadas $\mathrm{AIR}_{\mathrm{MAX}}$ e $A \mathrm{AR}_{\mathrm{MIN}}$ possibilitou o melhor entendimento do processo inflamatório induzido pela administração subcutânea da sílica SBA-15. 


\section{OBJETIVOS}

Os objetivos desse estudo basearam-se na eficácia da sílica nanoestruturada SBA-15 como adjuvante em processos de imunização pela via oral e a resposta inflamatória aguda induzida após administração subcutânea da nanopartícula.

Entre os parâmetros avaliados encontra-se a resposta humoral ao nível de mucosas e a caracterização morfológica e celular das placas de Peyer e linfonodos mesentéricos em camundongos BALB/c imunizados com a vacina contra Hepatite $A$ ou gama globulina humana adsorvida a SBA-15, comparativamente aos antígenos não adsorvidos.

Além disso, a análise quantitativa e qualitativa das células do exsudato inflamatório das linhagens geneticamente selecionadas para máxima e mínima resposta inflamatória aguda $\left(A I R_{M A X}\right.$ e $\left.A I R_{M I N}\right)$ serviu como parâmetro para comparação com a resposta inflamatória no nível das mucosas para melhor definir o potencial adjuvante da SBA-15. 


\section{MATERIAIS E MÉTODOS}

\subsection{Potencial de encapsulação/adsorção da gama globulina humana a SBA-15}

O potencial de encapsulação/adsorção da proteína de $150 \mathrm{kDa}$ gama globulina humana (HGG) (Sigma-Aldrich Biotechnology Co., St. Louis, MO, EUA) a sílica SBA-15 foi determinado através de ensaios in vitro utilizando-se diferentes proporções $(1: 5,1: 10,1: 25,1: 30)$ de HGG:SBA-15 (v/v) diluída em tampão fosfato $\mathrm{pH}$ 7,4 (PBS) em volume final de $1 \mathrm{~mL}$. As proteínas não encapsuladas/adsorvidas foram removidas por centrifugação a $400 \times \mathrm{g}$ por 5 minutos. Determinou-se a concentração em $\mathrm{mg} / \mathrm{mL}$ de HGG no sobrenadante por leitura a $\lambda 280 \mathrm{~nm}$ em espectrofotômetro. Como controle, utilizou-se solução de HGG $(50 \mu \mathrm{g} / \mathrm{mL})$ em volume final de $1 \mathrm{~mL}$ de PBS.

\subsection{Animais}

O efeito adjuvante da sílica SBA-15 pela via oral foi estudado em fêmeas de camundongos isogênicos $B A L B / c$, entre 8 e 12 semanas de idade criados e fornecidos pelo Biotério Central do Instituto Butantan. Estes camundongos têm perfil genético conhecido, apresentando uniformidade fenotípica. Para avaliação da resposta inflamatória aguda induzida pela sílica SBA-15 foram utilizados fêmeas de camundongos, entre 8 e 12 semanas de idade, das linhagens $A_{I R}$ MAX e $A_{I I R}$ obtidas por seleção genética segundo a alta ou baixa reatividade inflamatória aguda, respectivamente, contra o Biogel P-100 (Bio-Rad, Marnes-la-Coquette, França), substância de poliacrilamida, não-antigênica e quimicamente inerte (IBAÑEZ et al., 1992; CARNEIRO et al., 2002). Esses animais foram gentilmente cedidos pelo Dr. Orlando Garcia Ribeiro do Laboratório de Imunogenética do Instituto Butantan.

Todos os procedimentos envolvendo animais foram aprovados pelas Comissões de Ética em Experimentação Animal do Instituto Butantan e do Instituto de Ciências Biomédicas da USP. 


\subsection{Sílicas mesoporosas altamente ordenadas}

A sílica mesoporosa SBA-15 foi fornecida pelo Dr. Jivaldo R. Matos do Instituto de Química da Universidade de São Paulo e pela Dra. Márcia C. A. Fantini do Laboratório de Cristalografia do Instituto de Física da USP. As amostras de SBA15 foram sintetizadas utilizando um copolímero tribloco, o poli-(óxido de etileno)poli-(óxido de propileno)-poli-(óxido de etileno) (Pluronic P123, $\mathrm{EO}_{20} \mathrm{PO}_{70} \mathrm{EO}_{20}, \mathrm{PM}=$ 5800 - BASF Chemical Co., Mount Olive, NJ, EUA), o tetraetil-ortosilicato (TEOS) foi adquirido da Fluka/Sigma Chemical Co. (Milwaukee, WI, EUA). O ácido hidroclorídrico foi adquirido da Fisher Scientific Co. (Pittsburgh, PA, EUA). Todos os reagentes foram utilizados segundo protocolo de instrução. A caracterização da síntese e a adsorção das amostras foram seguidas conforme descrito por Matos et al. (2001).

\subsection{Imunização via oral (VO)}

Para avaliação do efeito adjuvante da SBA-15, camundongos BALB/c ( $n=$ 3/grupo) foram imunizados por gavagem com vacina contra Hepatite $A$ EPAXAL $®$ (Berna Biotech Ltda., Berna, Suíça) $(0,48 \mu \mathrm{g} / \mathrm{animal})$ adsorvida ou não em SBA-15 (12 $\mu \mathrm{g} /$ animal) ou PBS (grupo controle), num volume final de 0,2 mL. A vacina contra Hepatite A em concentração final desejada de 0,48 $\mu \mathrm{g} / \mathrm{animal}$ foi diluída em PBS. Para a adsorção a sílica, a vacina foi misturada a SBA-15 (12 $\mu \mathrm{g}$ de SBA-15/animal) na proporção 1:25 de antígeno:SBA-15 (v/v).

Os estudos ampliaram-se utilizando HGG nas imunizações pela via oral. Para determinar a melhor dose antígeno:sílica a ser utilizada, BALB/c ( $n=4 / g r u p o$ ) foram imunizados por gavagem com diferentes concentrações de HGG (5, 10, 50 ou 100 $\mu \mathrm{g} /$ animal) adsorvida em SBA-15 (125, 250, 1250 ou $2500 \mu \mathrm{g} /$ animal), seguindo a proporção 1:25 de antígeno:SBA-15 (v/v), ou somente com HGG diluída em PBS (50 $\mu \mathrm{g} /$ animal) num volume final de $0,2 \mathrm{~mL}$. Optou-se por utilizar nas imunizações 10

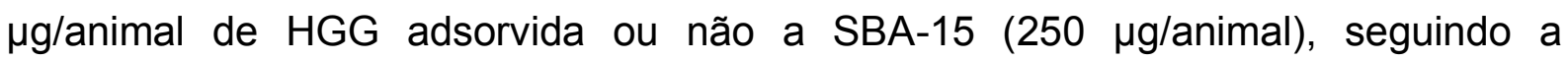
proporção 1:25 de antígeno:SBA-15 (v/v). Para a avaliação da resposta imune secundária, dose reforço foi administrada 45 dias após a primeira imunização. 
A proporção de sílica para a concentração de vacina e HGG teve por base estudos preliminares com proteínas de diferentes pesos moleculares. A relação escolhida para os imunógenos foi aquela cujo maior volume de proteína de peso molecular mais elevado adsorveu-se a SBA-15.

\subsection{Coleta das fezes}

Para coleta das fezes após a imunização, os animais dos diferentes grupos experimentais foram colocados em gaiolas sem maravalha por 30 minutos. Os pellets fecais foram ressuspendidos em PBS contendo $1 \mathrm{mM}$ de fluoreto de fenilmetilsulfonil (PMSF - Boehringer Mannheim Co., Indianapolis, IN, EUA) e 1\% de soro albumina bovina (BSA - Fisher Scientific Co., Fair Lawn, NJ, EUA) na proporção de um grama de fezes para $5 \mathrm{~mL}$ da solução. Após repouso de 15 minutos em gelo, foram agitados vigorosamente em agitador vórtex e depois de mais 15 minutos em repouso, as amostras foram novamente agitadas e centrifugadas a $22000 \times$ g durante 10 minutos. Os sobrenadantes foram removidos, distribuídos em alíquotas e estocados $\mathrm{a}-80{ }^{\circ} \mathrm{C}$ para posterior análise de produção de anticorpos por ELISA.

\subsection{Determinação dos títulos de anticorpos IgA e IgG anti-Hepatite A e anti- gama globulina humana por ELISA}

Os títulos de anticorpos séricos (IgG total, $\lg G 1$, $\lg G 2 a$ e $\lg A$ ) e $\lg A$ secretada nas fezes anti-Hepatite A e anti-HGG foram determinados pelo teste de ELISA (Enzyme-Linked Immunosorbent Assay) (ENGVALL e PERLMAN, 1971). As dosagens foram realizadas em microplacas de 96 poços com propriedade de alta ligação Maxisorp (Nalgene Nunc International, Rochester, NY, EUA) sensibilizadas com $1 \mu \mathrm{g} / \mathrm{mL}$ dos antígenos diluídos em tampão Carbonato-Bicarbonato $\mathrm{pH}$ 9,6 (0,05 $\mathrm{M} \mathrm{Na}_{2} \mathrm{CO}_{3}$ e $0,05 \mathrm{M} \mathrm{NaHCO}_{3}$ ) por 16 horas a $4{ }^{\circ} \mathrm{C}$. Após este período inicial de incubação, as placas foram lavadas 3 vezes com tampão PBS contendo Tween a 0,05\% (PBS-T). Após a lavagem, as placas foram bloqueadas com $0,5 \%$ de gelatina em PBS-Tween (PBS-T/gelatina) por 2 horas a $37{ }^{\circ} \mathrm{C}$. As amostras foram distribuídas e diluídas em série no diluente PBS-T/Gelatina 0,5\%, incubadas durante 
1 hora a $37^{\circ} \mathrm{C}$ para dosagem de IgG e seus isótipos e por 18 horas para IgA sérica e secretada. As placas foram lavadas e $100 \mu \mathrm{L}$ dos anticorpos anti-lgG (diluídos 1: 2000), anti-lgG1, anti-lgG2a (diluídos 1: 1000) ou anti-lgA (diluído 1: 500) marcados com peroxidase (Promega Co., Madison, WI, EUA) foram adicionados e as placas incubadas durante 1 hora a temperatura ambiente. Seguiu-se lavagem 3 vezes em PBS-T e $100 \mu \mathrm{l}$ do tampão substrato (20 mg OPD diluído em $40 \mathrm{~mL}$ tampão CitratoFosfato pH 5,0 - 0,1 M ácido cítrico; fosfato de sódio bifásico $0,2 \mathrm{M} / \mathrm{H}_{2} \mathrm{O}_{2} 0,3 \%$ ) foi adicionado; as placas foram mantidas no escuro até a reação ser revelada. A reação foi interrompida com $50 \mu \mathrm{L}$ /poço de ácido cítrico a $0,2 \mathrm{M}$. A leitura foi feita em $\lambda 450$ nm utilizando-se leitor de ELISA (Multiskan - Labsystems, Helsinki, Finlândia). Os títulos foram calculados desprezando-se $20 \%$ do valor da absorbância da diluição de saturação e expressos em $\log _{2}$.

\subsection{Análise morfológica e histológica das placas de Peyer}

Os camundongos dos diferentes grupos experimentais foram sacrificados 1, 3 e 7 dias após tratamentos para remoção e análise morfológica das placas de Peyer. Seguindo-se de suas localizações no intestino delgado, as placas de Peyer foram retiradas e lavadas com água destilada para remover resíduos de fezes. Os tecidos foram fixados em formaldeído $10 \%$ e, após 24 horas, incluídos em parafina para obtenção dos cortes histológicos. As lâminas foram coradas por hematoxilinaeosina. Os estudos sobre a morfologia das placas de Peyer foram realizados em colaboração com as Dras. Solange Barros Carbonare e Milene Tino de Franco, ambas do Laboratório de Imunogenética do Instituto Butantan.

\subsection{Imunofenotipagem das células das placas de Peyer e linfonodos mesentéricos}

\subsubsection{Obtenção das células}

Placas de Peyer (4-6 placas/animal) e linfonodos mesentéricos de camundongos BALB/c dos diferentes grupos experimentais foram retiradas do intestino delgado e lavadas com água destilada para remoção das fezes. Em 
seguida, foram colocadas em tubos de $15 \mathrm{~mL}$ contendo $3 \mathrm{~mL}$ de meio RPMI 1640 (Cultilab Ltda., São Paulo, SP, Brasil) e 5\% de soro fetal bovino (SFB - Cultilab Ltda., São Paulo, SP, Brasil). As placas foram vertidas em placas de Petri estéreis $(60 \times 15$ $\mathrm{mm}$ ) cobertas por um tecido de nylon estéril e maceradas. $O$ tecido foi lavado com 1 $\mathrm{mL}$ de meio RPMI para recuperação das células. A suspensão celular obtida foi transferida para tubos de $15 \mathrm{~mL}$ e, em seguida, centrifugada a $300 \mathrm{x}$ g por 8 minutos a $4{ }^{\circ} \mathrm{C}$. Os pellets obtidos foram ressuspendidos em $1 \mathrm{~mL}$ de meio RPMI. As células foram lavadas e centrifugadas novamente e os pellets novamente dispersos em 1 mL de tampão FACS (PBS - BSA 1\% - Azida Sódica 0,01\%). As células foram contadas em câmara de Neubauer e a viabilidade determinada com Azul de Trypan. As amostras foram mantidas a $4^{\circ} \mathrm{C}$ durante todo o procedimento.

\subsubsection{Análise por citometria de fluxo}

Células das placas de Peyer e linfonodos mesentéricos de animais tratados foram caracterizadas por citometria de fluxo quanto às moléculas expressas em sua superfície. Em placas de 96 poços (Corning-Costar Corp., Cambridge, MA, EUA), $100 \mu \mathrm{L}$ da suspensão celular $\left(2-5 \times 10^{5}\right.$ células $\left./ \mathrm{mL}\right)$ foram adicionados por poço e as placas centrifugadas a $300 \times \mathrm{g}$ por 8 minutos a $4{ }^{\circ} \mathrm{C}$. Anticorpos monoclonais conjugados (BD Bioscience, San Jose, CA, EUA) com fluorocromo fluoresceína (FITC) ou ficoeritrina (PE) anti-CD4 (Clone RM4-5; FITC), anti-CD8a (Clone 53-6.7; PE), anti-CD45R/B220 (Clone RA3-6B2; FITC), anti-CD11b (Clone M1/70; FITC), anti-CD11c (Clone HL3; FITC) e anti-CD25 (Clone 3C7; PE) foram adicionados (1 $\mu \mathrm{L}$ (poço); as placas foram incubadas no escuro por 30 minutos a $4{ }^{\circ} \mathrm{C}$. Passado o período de incubação, procedeu-se à lavagem por duas vezes com tampão FACS e centrifugadas novamente. As células foram ressuspendidas em $250 \mu \mathrm{L}$ de tampão FACS acrescido de 1\% paraformaldeído para aquisição no citômetro de fluxo (FacScalibur - BD Bioscience, San Jose, CA, EUA). A operação do citômetro e a análise dos resultados foram realizadas em colaboração com o Dr. Jorge Mario da Costa Ferreira Júnior do Laboratório de Imunoquímica do Instituto Butantan. 


\subsection{Indução da reação inflamatória e caracterização dos tipos celulares}

O processo inflamatório foi induzido em camundongos ( $n=4 /$ grupo) das linhagens $A I R_{\text {MAX }}$ e $A I R_{\text {MIN }}$, fêmeas com 8 a 12 semanas de idade, seguindo 0 modelo de bolsa de ar para desenvolvimento da inflamação (IBAÑEZ et al., 1992). A partir da indução de bolsa de ar simultaneamente produzida subcutaneamente no dorso, os animais receberam diferentes doses da sílica SBA-15 (250 $\mu \mathrm{g} / \mathrm{animal} ; 500$ $\mu \mathrm{g} /$ animal; $2500 \mu \mathrm{g} /$ animal) ou $250 \mu \mathrm{g}$ /animal de $\mathrm{Al}(\mathrm{OH})_{3}$ em volume final de 0,2 mL de PBS estéril. No grupo controle, animais receberam somente PBS estéril. $O$ exsudato inflamatório dos grupos experimentais foi recolhido em diferentes períodos (24; 72; 96 horas) procedendo-se a 3 inoculações/aspirações consecutivas na bolsa de ar com $1 \mathrm{~mL}$ de PBS acrescido de 20 unidades (U) de heparina. Para a quantificação das células, $10 \mu \mathrm{L}$ do exsudato total recolhido foram diluídos em $10 \mu \mathrm{L}$ de corante azul de metileno e a contagem do número total de células efetuada em câmara hemocitométrica de Neubauer. Em seguida, $5 \times 10^{4}$ células $/ \mathrm{mL}$ em volume final de 0,2 $\mathrm{mL}$ foram aplicados em lâminas de vidro, centrifugadas a $400 \times \mathrm{g}$ por 5 minutos e coradas com Instant Prov (Newprov, Pinhais, PR, Brasil). Para a análise da resposta empregou-se a técnica de Citospin (Shandon Cytospin 4 Shandon/Thermo Electron Co., Waltham, MA, EUA), determinando-se o influxo de monócitos e polimorfonucleares nos três tempos, através de contagem diferencial.

\subsection{Análises estatísticas}

Os resultados são expressos como: média (x) e desvio padrão (SD) e estatisticamente analisados pelo teste paramétrico $t$ de Student e considerados significativos quando $p \leq 0,05$. 


\section{RESULTADOS E DISCUSSÃO}

\subsection{Análise do potencial de encapsulação/adsorção da gama globulina humana à sílica nanoestruturada SBA-15}

Demonstrou-se através de ensaio de encapsulação/adsorção que proteínas como a Intimina $1 \beta(16,5 \mathrm{kDa})$ e BSA (66 kDa) são facilmente encapsuladas a SBA-15, fato que potencializa a resposta imune devido a proteção e liberação controlada desses antígenos nos processos de imunização (CARVALHO, 2007).

A análise in vitro do potencial de encapsulação/adsorção da proteína de 150 kDa gama globulina humana (HGG) a SBA-15 mostrou que aproximadamente $20 \%$ da HGG encontrava-se livre no sobrenadante e $\sim 80 \%$ adsorvida à SBA-15 nas proporções de 1:5, 1:10, 1:25 e 1:30 (antígeno:SBA-15) (Tabela 1).

Tabela 1- Potencial de adsorção da gama globulina humana a sílica nanoestruturada SBA-15.

\begin{tabular}{ccc}
\hline $\begin{array}{c}\text { Proporção } \\
\text { HGG:SBA-15 }\end{array}$ & $\begin{array}{c}\text { Porcentagem } \\
\text { HGG livre }\end{array}$ & $\begin{array}{c}\text { Porcentagem } \\
\text { HGG adsorvida }\end{array}$ \\
\hline HGG & $100 \%$ & $0 \%$ \\
$\mathbf{1 : 5}$ & $15,5 \%$ & $84,5 \%$ \\
$\mathbf{1 : 1 0}$ & $29,1 \%$ & $70,9 \%$ \\
$\mathbf{1 : 2 5}$ & $12,6 \%$ & $87,4 \%$ \\
$\mathbf{1 : 3 0}$ & $26,9 \%$ & $73,1 \%$ \\
\hline
\end{tabular}

Porcentagem de gama globulina humana livre no sobrenadante e adsorvida em SBA-15. Resultados expressos em porcentagem e representativos de dois experimentos independentes.

Esses dados indicam que a HGG provavelmente não fica retida nos poros dessa nanopartícula. Ressalte-se que a SBA-15 apresenta poros de 3 a $6 \mathrm{~nm}$. Assim, sugere-se que ocorra a adsorção e não a encapsulação da HGG a SBA-15, o que pode facilitar a captura dos antígenos pelas APC presentes nas placas de Peyer e proteger alguns epítopos contra degradação enzimática ao passarem pelo trato gastrointestinal. $O$ mesmo deve acontecer com a vacina contra Hepatite A que contém o vírus (cepa RG-SB) inativado da Hepatite A, cuja partícula apresenta diâmetro aproximado de 28 nm (MELNICK, 1992; MARTIN e LEMON, 2006; BOVIER, 2008). 


\subsection{Estudo do potencial adjuvante da sílica nanoestruturada SBA-15 em imunizações pela via oral}

Como referido, estudos anteriores demonstraram a capacidade da SBA-15 em potencializar e modular positivamente a resposta de anticorpos de animais isogênicos (BALB/c) e geneticamente selecionados ( $H_{\| l} ; L_{I I I} ; H_{I V A}$ e $\left.L_{I V A}\right)$ para alta ou baixa produção de anticorpos imunizados por diferentes vias (subcutânea, intraperitoneal, intramuscular e oral) com antígenos de naturezas diversas (Intimina $1 \beta$; veneno de $M$. ibiboboca e BSA) encapsulados/adsorvidos a SBA-15 (MERCURI et al., 2006; CARVALHO, 2007). Este fato nos motivou a dar continuidade aos estudos do efeito adjuvante da SBA-15 em imunizações pela via oral com outros antígenos, ressaltando o potencial dessa nanopartícula como adjuvante de mucosas. Por ser sintetizada em meio ácido, sugere-se que a SBA-15 apresente-se estável nas diversas condições do trato gastrointestinal e que atue na preservação do antígeno a ela encapsulado ou adsorvido, mantendo sua imunogenicidade e ativando efetivamente o sistema imune.

\subsubsection{Efeito da SBA-15 na produção de anticorpos IgA secretada (s-lgA) em imunizações com vacina contra Hepatite A pela via oral}

A análise da produção de anticorpos iniciou-se em camundongos isogênicos $B A L B / c$ ( $n=3$ animais/grupo) que receberam pela via oral a vacina contra Hepatite $A$ adsorvida a SBA-15 ou diluída em PBS; o grupo controle recebeu apenas PBS. Dez dias após imunização, as fezes foram coletadas para determinação dos títulos de s$\lg \mathrm{A}$.

A Figura 2 evidencia diferença nos títulos de anticorpos s-lgA anti-Hepatite A produzidos após administração da vacina contra Hepatite A em SBA-15 comparativamente ao grupo imunizado somente com a vacina ou PBS. Os níveis aumentados de anticorpos no grupo imunizado com a vacina adsorvida a SBA-15 mostram que a sílica potencializou a resposta imune, exercendo seu efeito adjuvante. 


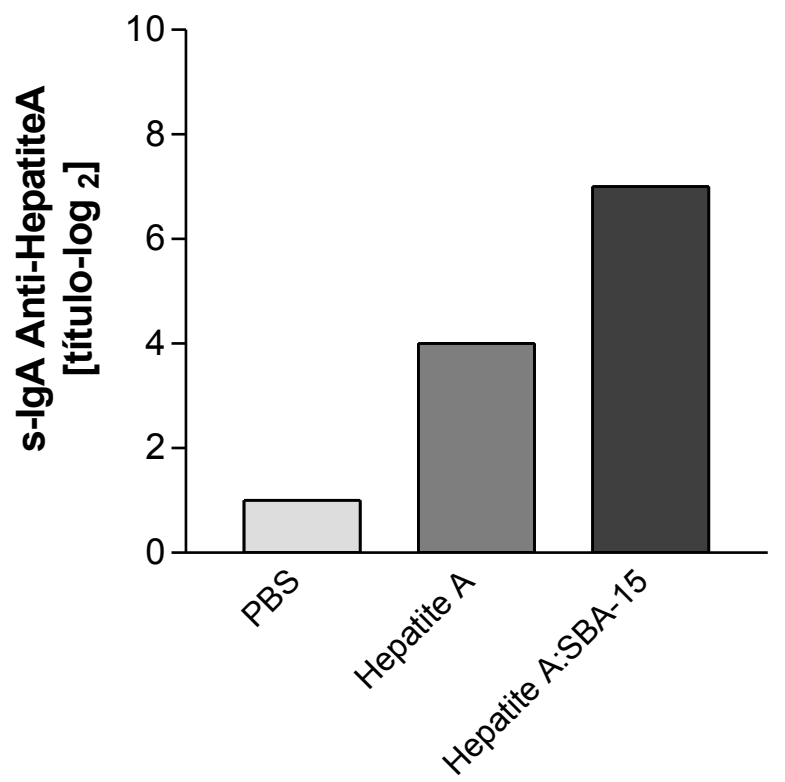

Figura 2- Títulos de s-lgA anti-Hepatite $A$ produzidos por camundongos BALB/c imunizados pela via oral. Anticorpos dosados pelo método de ELISA no $10^{\circ}$ dia após administração da vacina; $\mathrm{n}=3$ animais/grupo.

Micro-organismos comensais e antígenos provenientes da alimentação estimulam constantemente o sistema imunológico culminando na produção de anticorpos por mecanismos dependentes ou independentes de linfócitos T. A presença desses anticorpos, especialmente os da classe IgA, auxilia na manutenção do equilíbrio da flora intestinal, impedindo que patógenos penetrem na mucosa e facilitando a captura dos mesmos pelas células M (KRAEHENBUHL e CORBETT, 2004; CERUTTI e RESCIGNO, 2008). Dessa forma, espera-se que os processos de vacinação pela via oral resultem no estímulo à produção de anticorpos protetores da mucosa intestinal e, sobretudo, na indução de memória imunológica específica.

Tanto em camundongos quanto em humanos, as secreções das mucosas contém dímeros de imunoglobulina $A(\lg A)$, originados da interação entre monômeros de IgA e a cadeia J, um peptídeo sintetizado por plasmócitos. A ligação desses componentes ao receptor polimérico de imunoglobulinas (plgR), expresso nas células epiteliais da mucosa em suas superfícies basal e lateral, e ao componente secretor originado da clivagem do plgR permite a passagem da IgA para a luz intestinal por transcitose e confere à $\lg A$ secretada $(s-\lg A)$ propriedades mucofílicas importantes para a proteção do organismo contra patógenos (PHALIPON et al., 2002; CERUTTI, 2008). 


\subsubsection{Efeito da SBA-15 na produção de anticorpos séricos e secretados em imunizações com gama globulina humana pela via oral}

\subsubsection{Efeito dose-resposta e padronização da imunização com gama globulina humana}

Com a finalidade de determinar a melhor dose de HGG a ser utilizada nas imunizações pela via oral, camundongos BALB/c ( $n=4$ animais/grupo) receberam, seguindo a proporção 1:25 de HGG:SBA-15; 5, 10, 50 ou $100 \mu$ ge HGG adsorvida a SBA-15 em volume final de 0,2 mL por animal. Animais do grupo controle receberam $50 \mu \mathrm{g} / a n i m a l$ de HGG diluída em PBS. Para a análise da cinética da produção de anticorpos específicos séricos e secretados, sangrias e coletas das fezes foram realizadas no $7^{\circ}$ e $21^{\circ}$ dias da resposta primária e 10 dias após dose reforço, administrada 45 dias após a primeira imunização.

Não se observaram diferenças nos títulos de s-lgA e lgG sérica nas respostas primária e secundária entre os grupos de camundongos imunizados com diferentes doses de HGG em SBA-15 (Figura 3). Entretanto, no $7^{\circ}$ dia da resposta primária, os grupos que receberam HGG adsorvida a SBA-15 apresentaram níveis de IgG sérica aproximadamente 6 vezes superiores ao grupo imunizado somente com HGG (Figura 3B).

Diante desses resultados, optou-se por utilizar nas imunizações $10 \mu \mathrm{g}$ de HGG: $250 \mu \mathrm{g}$ de SBA-15 em volume final de 0,2 mL por animal. 


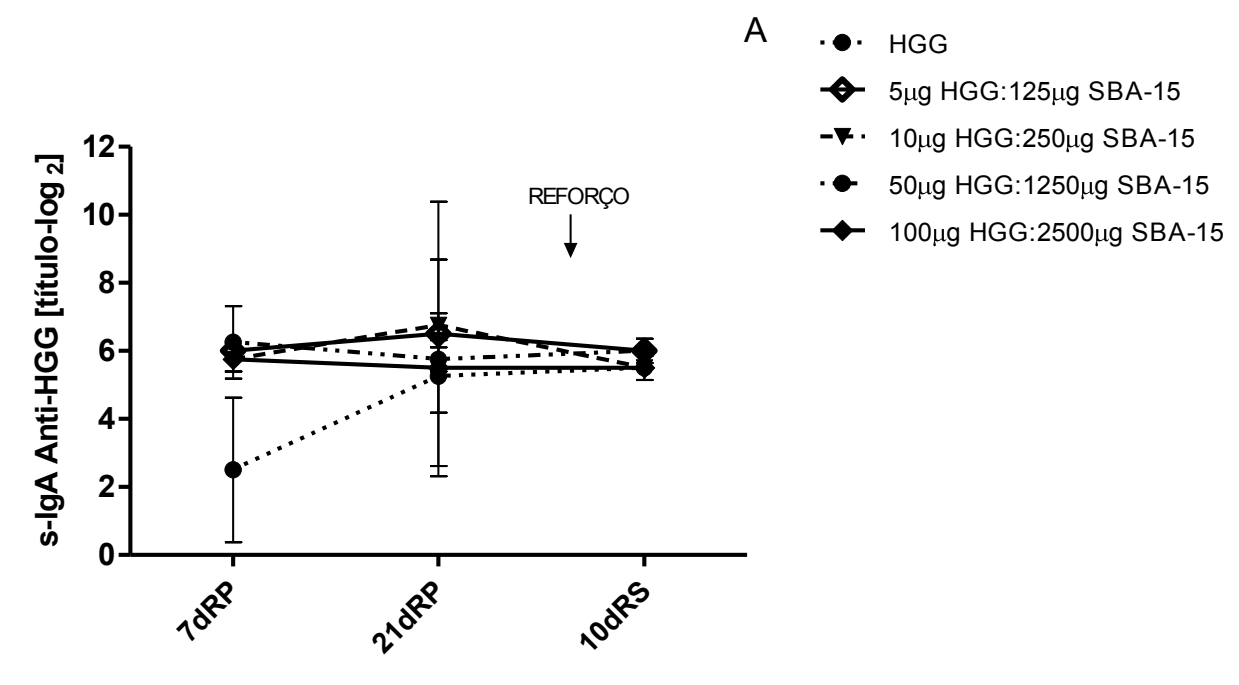

$\mathrm{B}$

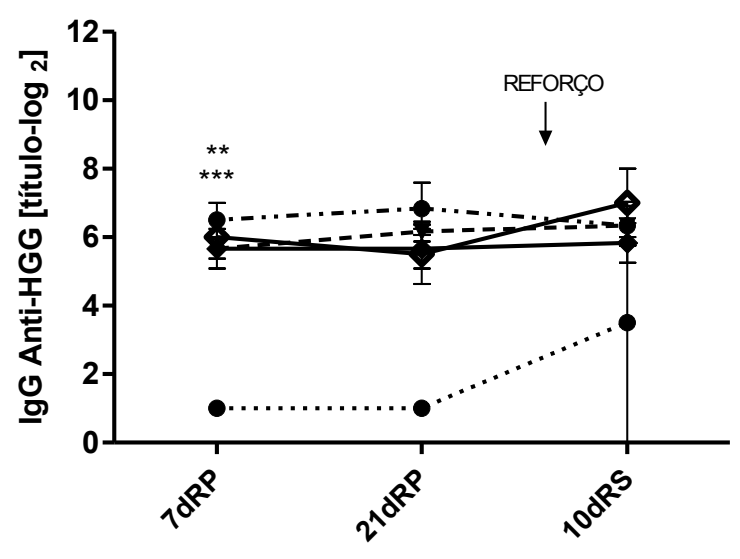

Figura 3- Títulos de s-lgA e IgG sérica anti-HGG produzidos por camundongos BALB/c imunizados pela via oral. Produção de anticorpos s-lgA (A) e $\lg G(B)$ após

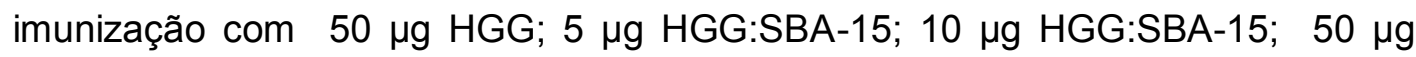
HGG:SBA-15 ou $100 \mu \mathrm{g}$ HGG:SBA-15. Dosagem realizada pelo método de ELISA no $7^{\circ}$ e $21^{\circ}$ dias da resposta primária e no $10^{\circ}$ dia da resposta secundária. Resultados expressos em média $\pm \mathrm{SD} ; \mathrm{n}=4$ animais/grupo; grupo de animais imunizados com $50 \mu \mathrm{g}$ HGG foi utilizado como referência para análise do teste $t$ de Student, ${ }^{* *} \mathrm{p}<0,01,{ }^{* * *} \mathrm{p}<0,001$.

\subsubsection{Análise da produção de anticorpos séricos e secretados das classes IgA e IgG anti-HGG após imunização com a sílica SBA-15}

Para ampliar os estudos sobre a utilização da SBA-15 como adjuvante de mucosas, avaliou-se a cinética de produção de anticorpos específicos séricos $(\lg A$, $\operatorname{lgG}$, IgG1 e $\lg G 2 a$ ) e secretados (s-lgA) nas respostas primária e secundária de 
camundongos BALB/c ( $\mathrm{n}=5$ animais/grupo) imunizados pela via oral com $10 \mu \mathrm{g}$ de HGG adsorvida ou não a SBA-15.

No $7^{\circ}$ dia da resposta primária, os títulos de lgG anti-HGG no soro de animais imunizados com o antígeno adsorvido a sílica mostraram-se 6 vezes superiores aos produzidos nos animais imunizados com o antígeno em PBS. Esses níveis mantiveram-se elevados após 21 dias da imunização e dose reforço (Figura 4A).

Em relação à lgA sérica, nos camundongos imunizados com HGG:SBA-15, os níveis de anticorpos específicos encontraram-se $\sim 6,5$ vezes aumentados aos 7 dias da imunização e cerca de 1,5 vezes maiores no $10^{\circ}$ dia após dose reforço comparativamente aos imunizados com HGG (Figura 4B). Analisando a s-IgA, a diferença entre os títulos de anticorpos dos grupos experimentais foi de 6 vezes no $7^{\circ}$ dia da resposta primária (Figura $4 \mathrm{C}$ ).

Em camundongos, a IgA circulante compõem cerca de $1 / 4$ do total de imunoglobulinas do soro; encontra-se principalmente na forma polimérica e não existem subclasses como o relatado em humanos. A IgA sistêmica liga-se a diversos receptores, expressos em granulócitos, monócitos, macrófagos, células dendríticas, eosinófilos, células dendríticas foliculares e hepatócitos, facilitando a internalização de bactérias opsonizadas. Pouco se sabe sobre esses receptores, mas acredita-se que atuem num contexto não-inflamatório na defesa contra bactérias intestinais. Por outro lado, a s-IgA das secreções mucosas têm o papel fundamental de ligar-se a microorganismos e toxinas presentes na luz intestinal, neutralizando-as e bloqueando a entrada de patógenos no hospedeiro. Na vacinação oral, a produção desses anticorpos é o principal mecanismo de indução de imunidade protetora (CERUTTI, 2008). 

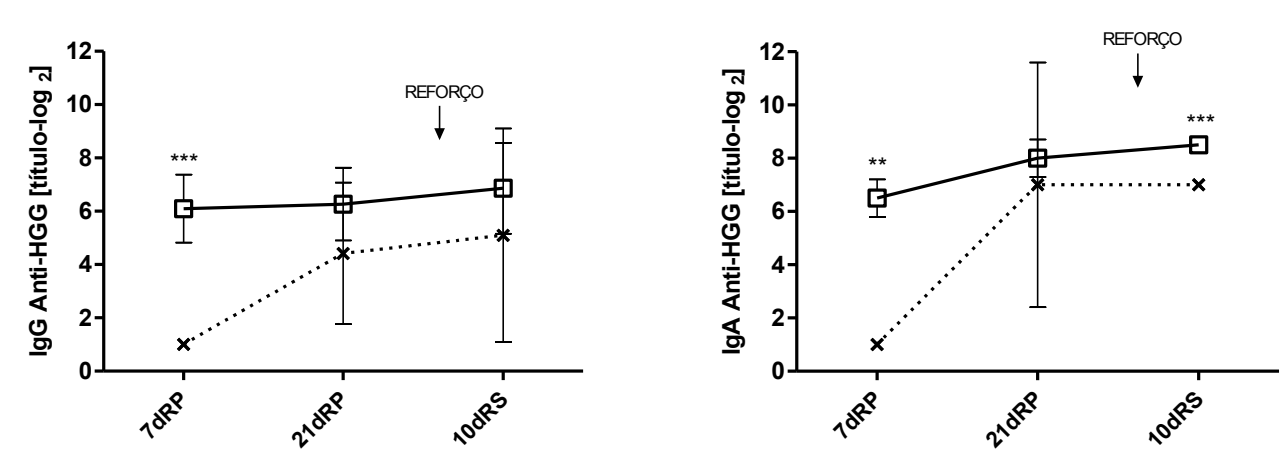

¥ HGG:SBA-15

C

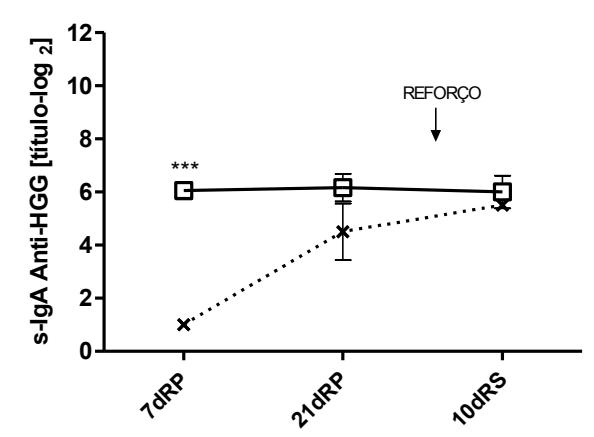

Figura 4- Títulos de anticorpos anti-HGG produzidos por camundongos BALB/c imunizados pela via oral. Títulos de $\lg G(\mathbf{A})$ e $\lg A(B)$ sérica e s-lgA (C) após imunização com HGG ou HGG:SBA-15. Dosagem realizada pelo método de ELISA no $7^{\circ}$ e $21^{\circ}$ dias da resposta primária e no $10^{\circ}$ dia da resposta secundária. Resultados de dois experimentos independentes expressos em média $\pm \mathrm{SD} ; \mathrm{n}=5$ animais/grupo; grupo de animais imunizados com HGG foi utilizado como referência para análise do teste $t$ de Student, ${ }^{* *} p<0,01,{ }^{* * *} p<$ 0,001 .

Esses resultados promissores comprovam o papel adjuvante da sílica nanoestrurada SBA-15 nas imunizações pela via oral. Acredita-se que a adsorção do antígeno a SBA-15 seja importante na proteção de epítopos contra a degradação enzimática promovida pelo trato gastrointestinal e na facilitação da sua captura pelas APC das placas de Peyer, potencializando a resposta imune através da apresentação de epítopos preservados as células imunocompetentes.

Estudos anteriores demonstraram que a SBA-15 não influencia qualitativamente a resposta imune quanto à determinada classe de linfócitos $T_{H}$ em imunizações pelas vias intraperitoneal e subcutânea, com antígenos como BSA e Intimina $1 \beta$, observando-se a produção tanto de $\lg G 1$ quanto de $\lg G 2 a$ 
(CARVALHO, 2007). Baseando-se nesses dados, avaliou-se a produção dos isótipos de lgG, lgG1 e lgG2a, durante as respostas primária e secundária de camundongos BALB/C ( $n=5$ animais/grupo) imunizados com HGG ou HGG adsorvida a SBA-15 pela via oral. Os resultados obtidos comprovaram a não influência da SBA-15 no direcionamento da resposta imune, observando-se a indução de resposta do tipo $T_{H} 1$ com predominância na produção de IgG2a tanto nos camundongos BALB/c imunizados com HGG quanto nos imunizados com HGG em SBA-15. No $21^{\circ}$ dia da resposta primária e no $10^{\circ}$ dia da resposta secundária, os títulos de lgG2a nos animais imunizados com HGG adsorvida a sílica foram discretamente superiores aos dos imunizados sem o adjuvante (Figura 5).

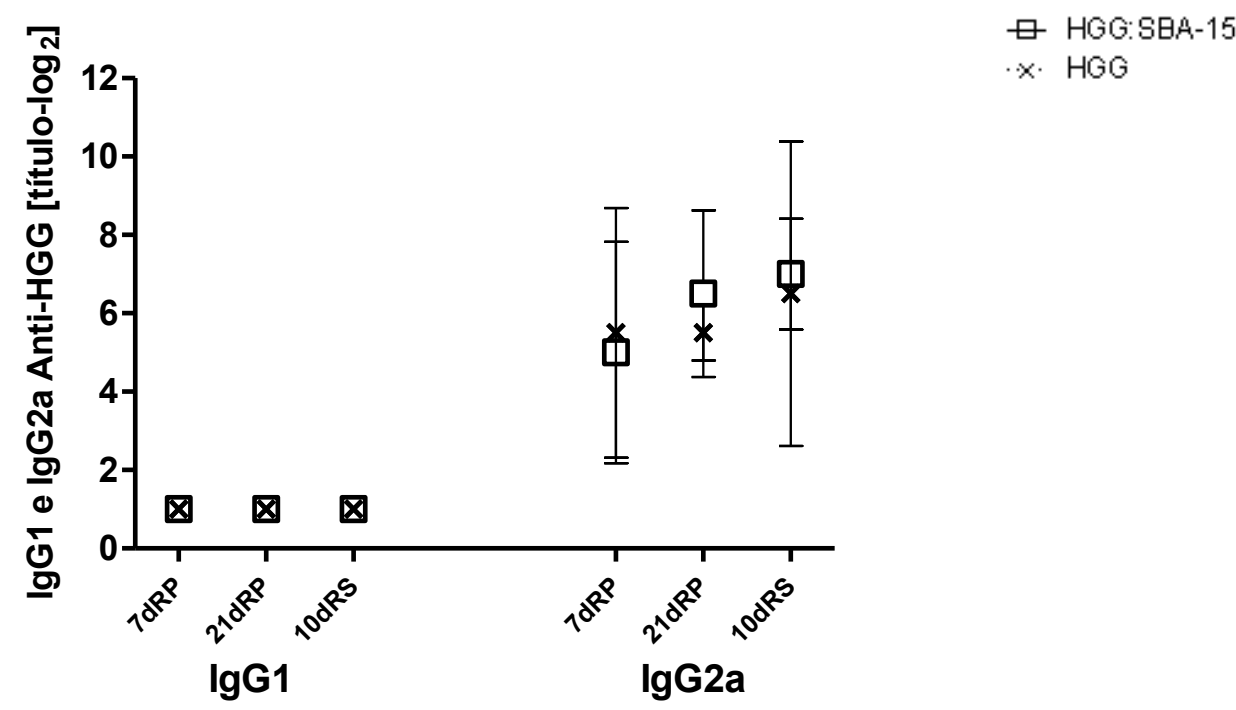

Figura 5- Títulos de anticorpos anti-HGG produzidos por camundongos BALB/c imunizados pela via oral. Títulos dos isótipos $\lg G 1$ e $\lg G 2 a$, após imunização com HGG ou HGG:SBA-15. Dosagem realizada pelo método de ELISA no $7^{\circ} \mathrm{e}$ $21^{\circ}$ dias da resposta primária e no $10^{\circ}$ dia da resposta secundária. Resultados de dois experimentos independentes expressos em média $\pm S D ; n=5$ animais/grupo; grupo de animais imunizados com HGG foi utilizado como referência para análise do teste $t$ de Student.

A diferenciação de linfócitos $T_{H}$ em subpopulações distintas de células efetoras depende dos estímulos presentes no início da resposta imune, como a presença de citocinas, a natureza do antígeno, a via de infecção, ativação ou não de células da imunidade inata e o uso de imunoestimuladores ou adjuvantes. No que se refere à imunização, a procura por um adjuvante que não interfira na polarização da 
resposta imunológica é de grande interesse; os resultados obtidos ao longo dos estudos sobre o efeito adjuvante da SBA-15 comprovam o alto potencial de aplicação dessa nanopartícula em processos de vacinação, especialmente pela via oral (COX e COULTER, 1997; BREWER, 2006).

\subsection{Efeito da SBA-15 na morfologia das placas de Peyer}

Para verificar possíveis alterações morfológicas nas placas de Peyer após imunização pela via oral, grupos de camundongos BALB/c ( $n=3$ animais/grupo) receberam a vacina contra Hepatite $A$ adsorvida ou não a SBA-15; como controles, grupos de animais receberam apenas SBA-15 ou PBS. Após 1, 3 e 7 dias, os animais foram sacrificados e tiveram suas placas de Peyer retiradas e analisadas morfologicamente (Figura 6).

A

Figura 6- Aspectos morfológicos das placas de Peyer de camundongos BALB/c. (A) Animal imunizado com vacina contra Hepatite A adsorvida em SBA-15. (B) Animal imunizado com vacina contra Hepatite A em PBS. (C) Animal tratado com PBS. (D) Animal tratado com SBA-15. Placas de Peyer retiradas 1 dia após os diferentes tratamentos. Figura representativa da análise macroscópica observada após 3 e 7 dias dos tratamentos. Placas de Peyer com cerca de $2 \mathrm{~mm}$ de diâmetro. 
Não se verificou alterações significativas na morfologia das placas de Peyer após análise macroscópica das estruturas após 1, 3 e 7 dias dos tratamentos. Embora tenha-se observado leve hipertrofia nas placas dos camundongos que receberam a vacina em SBA-15, essa característica não se manteve ao longo dos experimentos, observando-se, inclusive, hipertrofia das placas de animais não imunizados. Obviamente, fatores ambientais como condições do biotério e alimentação podem interferir diretamente nessas análises. Deve-se ressaltar que a zona de linfócitos $B$ das placas de Peyer não gera números significativos de plasmócitos em relação a outros centros germinativos, o que pode justificar a ausência de alterações morfológicas dessas estruturas quando comparados os diferentes dias e tratamentos (SHALABY, 1995).

Ainda, partículas com tamanhos entre 2-5 $\mu \mathrm{m}$ são facilmente capturadas pelas células $M$ das placas de Peyer, enquanto as menores do que $2 \mu \mathrm{m}$ e superiores a $10 \mu \mathrm{m}$ são rapidamente drenadas para os linfonodos mesentéricos (SHALABY, 1995; SMITH, 1998). Devido ao tamanho das partículas micronizadas de SBA-15 apresentarem cerca de $30 \mu \mathrm{m}$, sugere-se que essas não sejam capturadas pelas placas e não interfiram diretamente na sua morfologia servindo apenas de veículo carreador de antígenos.

No entanto, sete dias após imunização, o número total de células contidas nas placas retiradas encontrava-se aumentado nos animais que receberam a vacina e, em especial, nos que receberam a vacina adsorvida em SBA-15 (Tabela 2). Essa observação pode estar diretamente relacionada à proliferação celular devido ao desenvolvimento da resposta imune comprovada pelos níveis aumentados de s-lgA verificados nos camundongos imunizados com a vacina em SBA-15 (Figura 2). Durante o período avaliado, não foram observadas alterações significativas no número total de células dos animais que receberam SBA-15 e dos não imunizados. 
Tabela 2- Número total de células das placas de Peyer de camundongos BALB/c imunizados com vacina contra Hepatite A pela via oral.

\begin{tabular}{ccc}
\hline & \multicolumn{2}{c}{ Placas de Peyer } \\
\hline 3 dias & 7 dias \\
\hline HEP-A & $3,99 \pm 5,2$ & $8,33 \pm 2,1$ \\
HEP-A:SBA-15 & $7,48 \pm 1,9$ & $10,19 \pm 3,7$ \\
\hline
\end{tabular}

Placas de Peyer retiradas após 3 e 7 dias dos diferentes tratamentos; $n=3$ animais/grupo; 4 placas por animal - pool de células; (células $\times 10^{6} / \mathrm{mL}$ ). Resultados de dois experimentos independentes expressos em média \pm SD; grupo de animais imunizados com a vacina contra Hepatite A foi utilizado como referência para análise do teste $t$ de Student.

Análises histológicas das placas de Peyer um dia após imunização pela via oral de camundongos com a vacina contra Hepatite A adsorvida ou não a SBA-15 ou inoculação de SBA-15 ou PBS mostraram-se semelhantes entre si, observando-se a presença majoritária de linfócitos nos folículos linfóides (Figura 7).

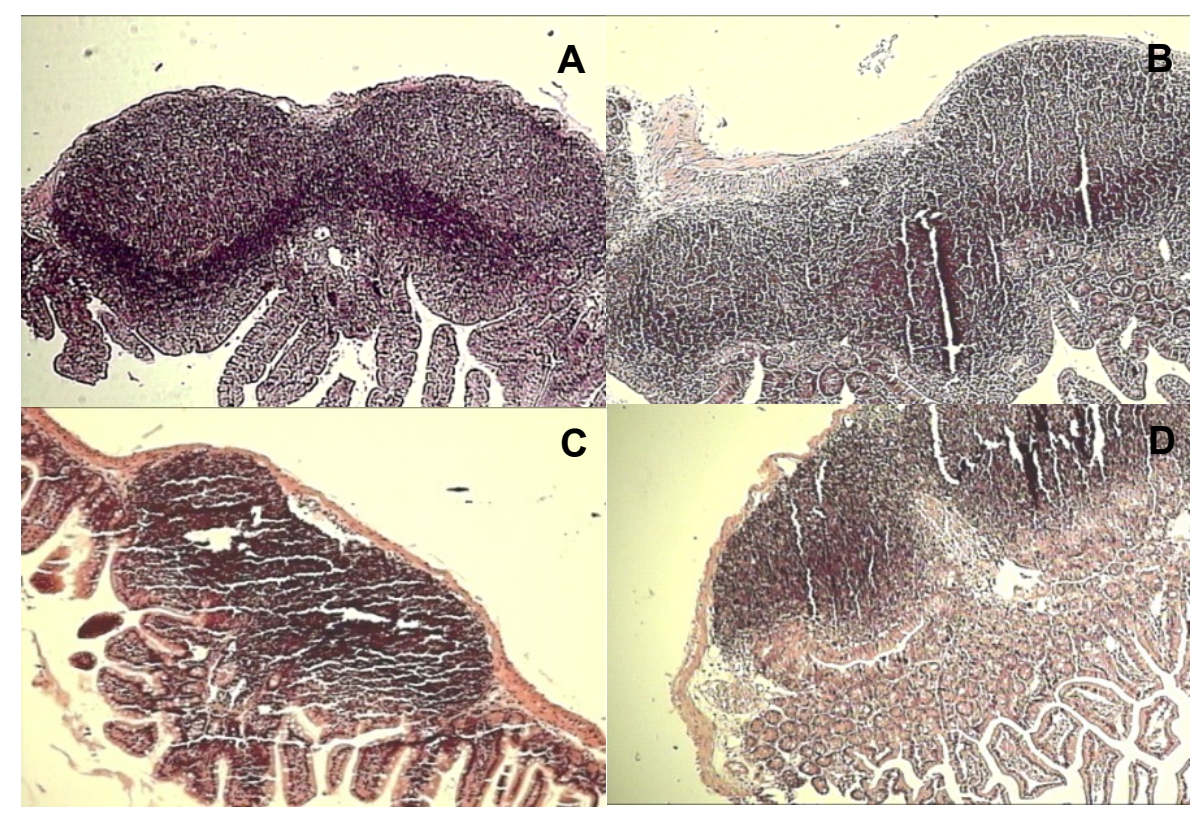

Figura 7- Análises histológicas das placas de Peyer de camundongos BALB/c. Camundongo BALB/c imunizado com vacina contra Hepatite A em PBS (A); com vacina contra Hepatite A adsorvida em SBA-15 (B); tratado com SBA-15 (C); tratado com PBS (D). Placas de Peyer retiradas após 1 dia dos diferentes tratamentos. Microscopia de luz; aumento de 10x; HE. 
De modo semelhante observou-se, após 1, 3 e 7 dias, aumento do número total de células tanto das placas de Peyer quanto dos linfonodos mesentéricos de animais imunizados com HGG:SBA-15 comparando-se ao grupo imunizado somente com HGG, fato que sugere proliferação de células imunocompetentes e indica a eficiência da sílica em potencializar a resposta imune. Nos linfonodos mesentéricos, o grupo de camundongos imunizados com HGG em sílica apresentou número total de células aproximadamente 35 vezes maior, 1 e 3 dias após imunização, em relação ao grupo imunizado com HGG em PBS nesse mesmo período (Tabela 3).

Tabela 3- Número total de células das placas de Peyer e linfonodos mesentéricos de camundongos BALB/c imunizados com gama globulina humana pela via oral.

\begin{tabular}{cccc|ccc}
\hline & \multicolumn{3}{c|}{ Placas de Peyer } & \multicolumn{3}{c}{ Linfonodos Mesentéricos } \\
\hline & 1 dia & 3 dias & 7 dias & 1 dia & 3 dias & 7 dias \\
\hline HGG & $6,5 \pm 2,2$ & $5,9 \pm 2,1$ & $13,4 \pm 3,1$ & $39,7 \pm 25,8^{*}$ & $32,0 \pm 14,9^{* * *}$ & $125,4 \pm 48,8$ \\
HGG:SBA-15 & $7,6 \pm 2,8$ & $8,0 \pm 2,4$ & $14,4 \pm 1,1$ & $73,3 \pm 12,3$ & $66,6 \pm 2,8$ & $171,6 \pm 78,3$ \\
\hline
\end{tabular}

Placas de Peyer e linfonodos mesentéricos retirados após 1, 3 e 7 dias dos diferentes tratamentos; $\mathrm{n}=3$ animais/grupo; $\mathrm{n}=6$ placas por animal - pool de células; (células $\mathrm{x}$ $10^{6} / \mathrm{mL}$ ). Resultados de dois experimentos independentes expressos em média \pm SD; grupo de animais imunizados com HGG foi utilizado como referência para análise do teste $t$ de Student, $p<0,05,{ }^{* * *} p<0,001$.

\subsection{Análises imunofenotípicas das células das placas de Peyer e linfonodos mesentéricos por citometria de fluxo após imunização pela via oral utilizando a sílica nanoestruturada SBA-15 como adjuvante}

\subsubsection{Imunofenotipagem das células das placas de Peyer}

\subsubsection{Imunização com vacina contra Hepatite A}

Para a avaliação qualitativa e quantitativa dos tipos celulares encontrados nas placas de Peyer, camundongos BALB/c ( $n=3$ animais/grupo) foram imunizados pela via oral com vacina contra Hepatite $A$ adsorvida ou não a SBA-15. As placas de 
Peyer foram coletadas após 3 e 7 dias da imunização e suas células avaliadas quanto a distribuição fenotípica com os marcadores de superfície celular CD4, CD8a, CD45R/B220, CD11b e CD11c por citometria de fluxo.

Comparando a distribuição fenotípica das células das placas de Peyer após 3 e 7 dias da imunização, observaram-se diferenças significativas nas populações de células $\mathrm{CD} 4^{+}, \mathrm{CD}^{+}$e B220 ${ }^{+}$(Figura 8).

Três dias após a imunização, a avaliação da freqüência de células CD4 ${ }^{+}$ indicou porcentagem 6 vezes maior desses tipos celulares no grupo de animais imunizados com a vacina em sílica comparativamente ao grupo imunizado com a vacina em PBS (Figura 8A). Em relação ao número total de células, observou-se que o grupo vacina:SBA-15 apresentou número relativamente maior de células durante todo o período analisado (Figura 8B).

Em relação às células $\mathrm{CD} 8^{+}$, observou-se no $3^{\circ}$ dia após imunização, freqüência aumentada no grupo imunizado com a vacina em sílica. A análise dos dados em número total de células, indicou aumento em $\sim 1,5$ vezes na quantidade de células $\mathrm{CD}^{+}$de animais imunizados com a vacina adsorvida a sílica, fato indicativo da proliferação de linfócitos $\mathrm{T}_{\mathrm{CD}} \mathrm{CD}^{+}$. Após 7 dias não houve diferença na porcentagem e número total de células entre os grupos experimentais (Figuras $8 \mathrm{C} \mathrm{e}$ 8D).

As placas de Peyer, ao contrário dos linfonodos, possuem população de linfócitos B aproximadamente 5 vezes maior comparativamente a população de linfócitos T (CERUTTI e RESCIGNO, 2008). A análise desses tipos celulares nos camundongos imunizados indicou que mais de $50 \%$ da população total de células das placas é B220 ${ }^{+}$. Após 3 dias da imunização, os grupos experimentais apresentaram a mesma freqüência de células $\mathrm{B} 220^{+}$; entretanto, no $7^{\circ}$ dia da imunização, houve aumento de $\sim 6,5$ vezes na freqüência celular de animais imunizados com a vacina adsorvida a SBA-15 (Figura 8E). Corroborando esses dados, o número de células $\mathrm{B} 220^{+}$no $7^{\circ}$ dia da imunização foi 5,6 vezes maior no grupo imunizado com antígeno adsorvido a sílica (Figura 8F).

A presença majoritária de linfócitos $B$ nas placas de Peyer é importante para o desenvolvimento de resposta protetora e correlaciona-se diretamente aos níveis aumentados de anticorpos s-lgA anti-Hepatite $A$ detectados após imunização com a vacina em SBA-15 (Figura 2), comprovando sua eficácia como adjuvante de mucosas. Ainda, o aumento dos números de linfócitos $B$ e $T$ após imunização com a 
sílica pode refletir a captura eficiente de epítopos preservados devido à proteção física gerada pela SBA-15, culminando no maior recrutamento e proliferação de células imunocompetentes.

A presença de macrófagos e células dendríticas nos primeiros três dias pósimunização em camundongos imunizados com a vacina em SBA-15 indica que houve recrutamento de APC para as placas de Peyer (Figuras $8 \mathrm{G}, 8 \mathrm{H}, 8 \mathrm{l}$ e $8 \mathrm{~J}$ ). Após 7 dias, observou-se a redução na freqüência e no número total de células $\mathrm{CD}_{11} \mathrm{~b}^{+}$e $\mathrm{CD} 11 \mathrm{c}^{+}$, provavelmente devido à migração desses macrófagos e células dendríticas para os linfonodos mesentéricos, que ocorre entre 3 e 4 dias após contato com o antígeno (KELSALL et al., 2005).

Os resultados obtidos corroboram com os achados da literatura que mostram que as placas contêm poucas APC e muitos linfócitos B e T, especialmente de memória. Ainda, contêm diferentes subpopulações de células dendríticas, com funções específicas dependendo do grau de ativação. Todas essas subpopulações apresentam como marcador de superfície o $\mathrm{CD} 11 \mathrm{c}^{\mathrm{HIGH}}$ e níveis semelhantes de MHC classe II e moléculas estimuladoras (BRANDTZAEG et al., 1999). 
A
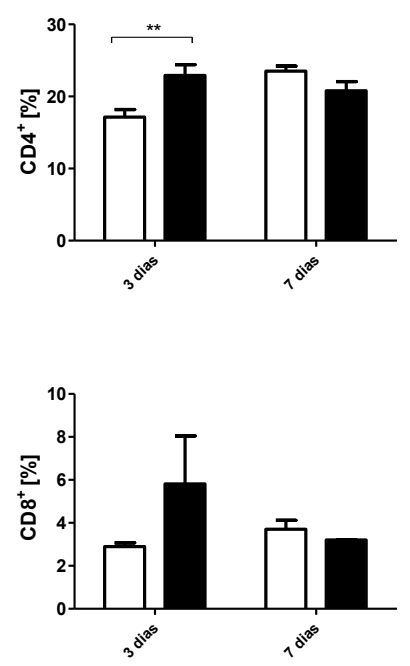

E

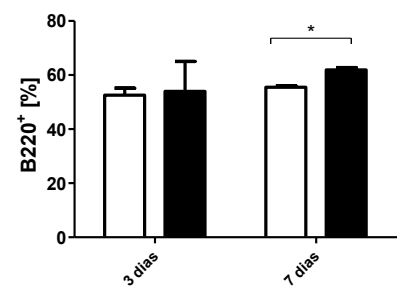

G
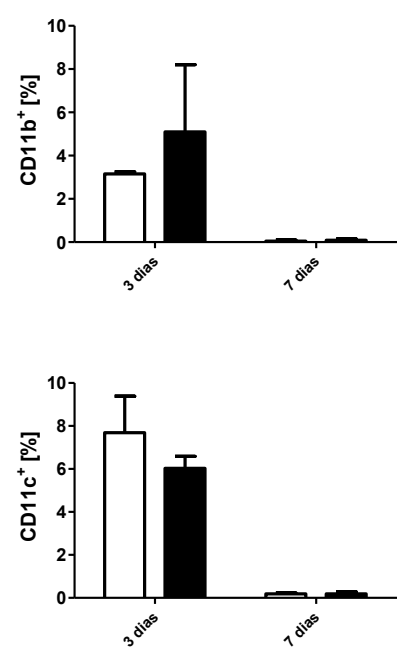

C
B
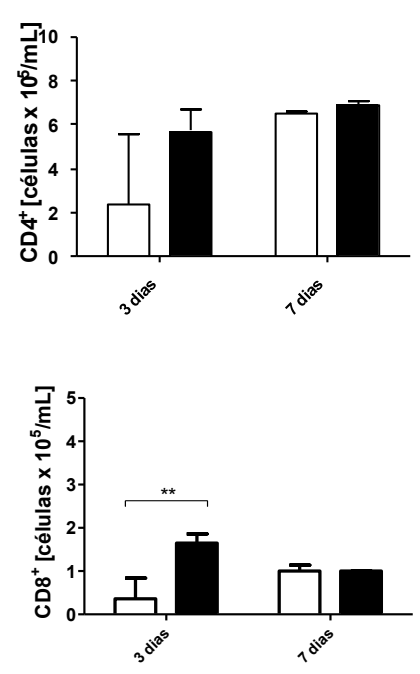

D

$\mathrm{F}$
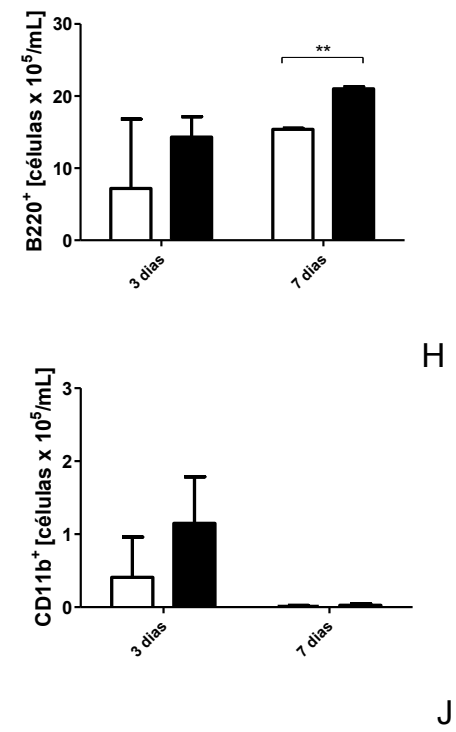

$\mathrm{H}$

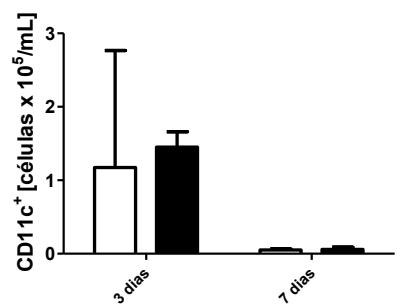

Figura 8- Distribuição fenotípica das células das placas de Peyer de camundongos BALB/c imunizados pela via oral. Camundongos imunizados com vacina contra Hepatite A ou vacina contra Hepatite A adsorvida em SBA-15. Freqüência (\%) de células $\mathrm{CD}^{+}(\mathbf{A}), \mathrm{CD}^{+}(\mathbf{C}), \mathrm{B220}^{+}(\mathbf{E}), \mathrm{CD} 1 \mathrm{~b}^{+}(\mathbf{G})$ e $\mathrm{CD} 11 \mathrm{c}^{+}(\mathbf{I})$ e número total (células $\times 10^{5} / \mathrm{mL}$ ) de células $\mathrm{CD}^{+}(\mathbf{B}), \mathrm{CD}^{+}(\mathbf{D}), \mathrm{B}^{2} 20^{+}(\mathbf{F}), \mathrm{CD} 11 \mathrm{~b}^{+}(\mathbf{H}) \mathrm{e}$ $\mathrm{CD}_{11 \mathrm{c}^{+}}(\mathbf{J})$ após 3 e 7 dias da imunização analisadas por citometria de fluxo. Resultados de dois experimentos independentes expressos em média $\pm S D ; n=$ 3 animais/grupo; grupo de animais imunizados com a vacina foi utilizado como referência para análise do teste $t$ de Student, ${ }^{*} p<0,05 ;{ }^{* *} p<0,01$. 


\subsubsection{Imunização com gama globulina humana}

Para comprovar a potencialização da resposta imune ao nível das mucosas através da análise qualitativa e quantitativa das células das placas de Peyer e linfonodos mesentéricos de camundongos BALB/c ( $n=3$ animais/grupo) imunizados pela via oral com HGG adsorvida ou não a SBA-15 após 1, 3 e 7 dias, realizou-se ensaio de citometria de fluxo. Os marcadores de superfície celular utilizados para a análise da distribuição fenotípica foram CD4, CD8a, CD45R/B220, CD11b e CD11C.

A freqüência de células $\mathrm{CD}^{+}$nas placas de Peyer de animais imunizados com HGG adsorvida a SBA-15 mostrou-se 3,6 vezes superior à observada no grupo imunizado com HGG diluída em PBS, no primeiro dia após imunização. Sete dias após, a freqüência desses tipos celulares foi 2 vezes superior no grupo HGG comparando-se ao grupo HGG:SBA-15 (Figura 9A). A análise do número total de células $\mathrm{CD}^{+}$nos dois grupos experimentais não evidenciou nenhuma diferença significativa entre eles (Figura 9B). No entanto, fica evidente que, tanto a freqüência quanto o número total de células $\mathrm{CD}^{+}$aumentam do $1^{\circ}$ ao $7^{\circ}$ dia da imunização, indicando a proliferação de linfócitos $T_{H}$ nas placas de Peyer.

Os dados obtidos referentes à freqüência de células $\mathrm{CD}^{+}$não indicaram diferenças relevantes entre os grupos experimentais (Figura 9C). Quando comparados o número total desses tipos celulares após 1 e 3 dias, verificou-se aumento no grupo HGG:SBA-15; entretanto, 7 dias após a imunização houve aumento de 2 vezes no número de células $\mathrm{CD}^{+}$de animais imunizados com HGG em PBS (Figura 9D). 
A

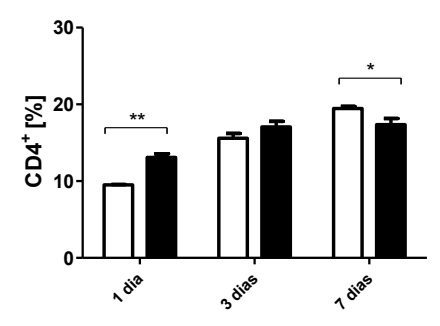

C

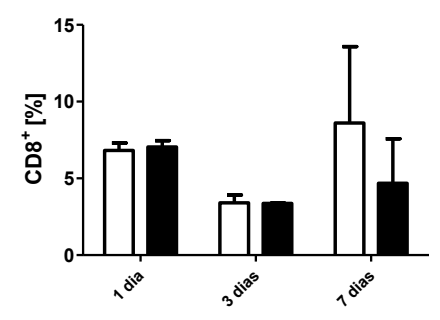

E

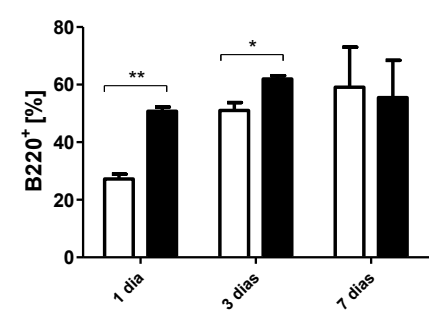

G
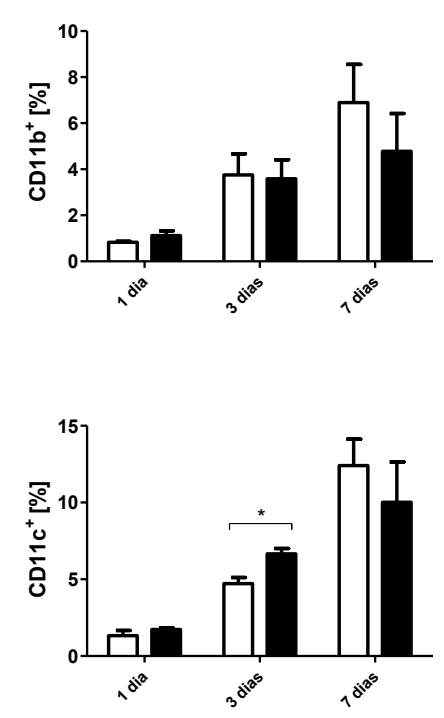

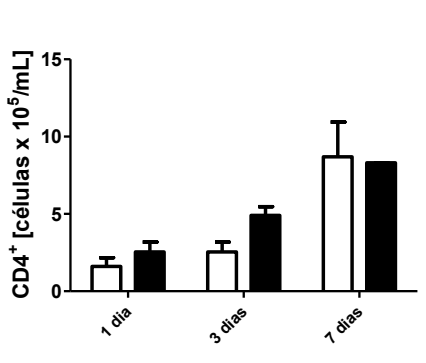

B ${ }_{\text {HGG:SBA-15 }}^{\text {HGG }}$

D

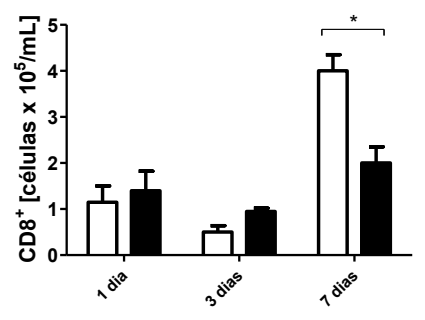

$\mathrm{F}$

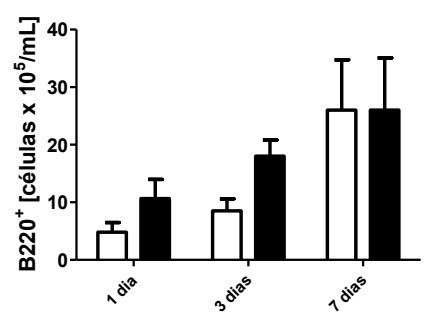

$\mathrm{H}$
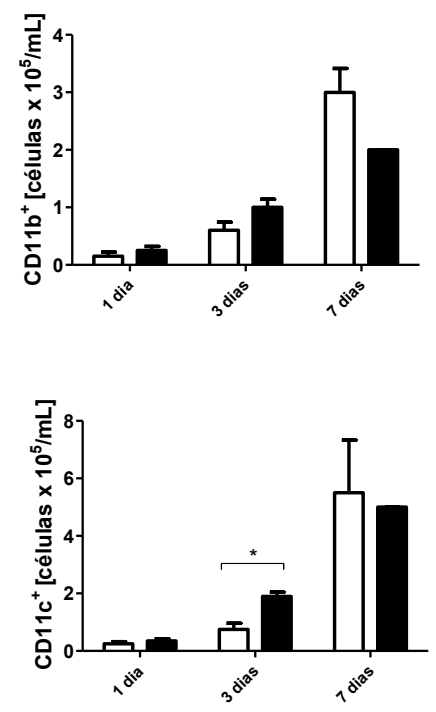

Figura 9- Distribuição fenotípica das células das placas de Peyer de camundongos BALB/c imunizados pela via oral. Camundongos imunizados com HGG ou HGG adsorvida em SBA-15. Freqüência (\%) de células $\mathrm{CD}^{+}(\mathbf{A}), \mathrm{CD}^{+}(\mathbf{C})$, $\mathrm{B}^{2} 20^{+}(\mathbf{E}), \mathrm{CD}_{11 \mathrm{~b}^{+}}(\mathbf{G})$ e CD11 ${ }^{+}(\mathbf{I})$ e número total (células $\times 10^{5} / \mathrm{mL}$ ) de células

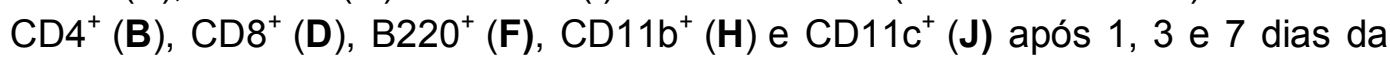
imunização analisadas por citometria de fluxo. Resultados de dois experimentos independentes expressos em média $\pm S D ; n=3$ animais/grupo; grupo de animais imunizados com HGG foi utilizado como referência para análise do teste $t$ de Student, ${ }^{*} p<0,05 ;{ }^{* *} p<0,01$. 
Os resultados referentes a células $\mathrm{B}^{2} 20^{+}$merecem ser destacados; mostrouse que a freqüência de células $\mathrm{B}^{2} 20^{+}$aumentou no grupo de animais imunizados com HGG:SBA-15 em 24 vezes após 1 dia da imunização, e 11 vezes após 3 dias comparativamente ao grupo imunizado com HGG em PBS (Figura 9E). De modo semelhante, observou-se aumento constante no número total dessas células ao longo do período analisado, indicando proliferação celular desencadeada pela resposta imune. Ainda, o grupo imunizado com HGG:SBA-15 apresentou número total de células $\mathrm{B}^{2} 20^{+}$superior em relação aos imunizados com HGG nos três períodos analisados (Figura 9F). Esses resultados corroboram com os dados de produção de anticorpos (Figura 4), indicando que a SBA-15 potencializou a resposta humoral desses animais, evidenciada pela produção elevada de anticorpos séricos e secretados e pela proliferação de linfócitos B produtores de anticorpos.

Com relação aos macrófagos e às células dendríticas, observou-se 0 aumento desses tipos celulares ao longo do período analisado, sugerindo que houve o recrutamento constante dessas APC para as placas até 7 dias após a imunização. O mesmo não foi observado nos ensaios com a vacina contra Hepatite A que indicou queda significativa na freqüência e no número dessas APC após 3 dias da imunização, provavelmente devido à migração desses fagócitos para os linfonodos mesentéricos (Figuras 9G, 9H, 9l e 9J). A análise da freqüência e número total de células $\mathrm{CD}_{11} \mathrm{~b}^{+}$nos três períodos avaliados indicou números semelhantes entre os grupos imunizados com HGG e com HGG em SBA-15 (Figuras 9G e 9H). Em contrapartida, células $\mathrm{CD}_{11 \mathrm{c}^{+}}$do grupo que recebeu HGG:SBA-15, 3 dias após a imunização, apresentou freqüência 2 vezes superior e número total de células $\sim 1,5$ vezes maior comparativamente ao grupo HGG. Após 7 dias, esse quadro se reverteu e os animais imunizados com HGG em PBS apresentaram freqüência e número total de células $\mathrm{CD}_{11 \mathrm{c}^{+}}$discretamente superiores aos dos imunizados com HGG em SBA-15 (Figuras 9l e 9J).

Nas placas de Peyer e linfonodos mesentéricos, células CD11 ${ }^{+}$, tipicamente detectadas como macrófagos, também identificam subpopulações de células dendríticas cuja função é capturar e apresentar antígenos. Essas células são produtoras de IL-10 e induzem a produção de IL-4 e IL-10 por linfócitos T CD4 ${ }^{+}$além de estimularem células endoteliais a produzir TGF- $\beta$, gerando a resposta do tipo $T_{H} 3$ típica de mucosas e supressão da resposta $T_{H} 1$, tipicamente desencadeada por microorganismos como S. typhimurium e T. gondii. Células dendríticas das mucosas 
têm propensão a induzir resposta do tipo $\mathrm{T}_{\mathrm{H}} 2$ após infecção, principalmente, contra antígenos protéicos devido ao microambiente rico em IL-4, IL-5 e IL-10 e supressão da resposta $T_{H} 1$ (KRAEHENBUHL e CORBETT, 2004; KELSALL e JOHANSSON, 2005; IWASAKI e KELSALL, 2008).

Os ensaios de citometria de fluxo evidenciaram presença de subpopulação de células com intensidade de fluorescência intermediária para o marcador de superfície celular B220, especialmente no $7^{\circ}$ dia após imunização (Figuras 10B e 10C). Essa subpopulação poderia corresponder a células dendríticas plasmocitóides $\left(\mathrm{B}^{2} 2 \mathrm{O}^{+} \mathrm{CD} 8 \mathrm{a}^{+}\right)$ou, mais provavelmente, indicar a presença de linfócitos $\mathrm{B}$ em diferentes estágios de ativação e expressão de B220. Vale ressaltar que os camundongos imunizados com HGG em SBA-15 apresentaram subpopulação B220 ${ }^{\text {LOW }}$ mais intensa (Figura 10E) que os imunizados com HGG em PBS (Figura 10D). A partir desse perfil celular, utilizou-se os marcadores de superfície CD8a e CD45R/B220 para a análise da distribuição fenotípica da população de células dendríticas plasmocitóides $(\mathrm{pDC})$.

Nas placas de Peyer observou-se aumento até o $7^{\circ}$ dia após imunização de células B220 ${ }^{+} \mathrm{CD} \alpha^{+}$nos grupos HGG e HGG:SBA-15 (Figuras 11A e 11B). Após 3 dias, o número de $\mathrm{pDC}$ foi 3 vezes maior no grupo de camundongos imunizados com HGG adsorvida em SBA-15 (Figura 11B). Células dendríticas plasmocitóides são encontradas no timo e em todos os órgãos linfóides secundários e consideradas importantes para a ligação entre a resposta imune inata e a adquirida. As pDC secretam grandes quantidades de IFN- $\alpha$ contribuindo para a geração de resposta específica de linfócitos $\mathrm{T} \mathrm{CD} 8^{+}$contra vírus ou na indução da diferenciação de linfócitos $T$ reguladores produtores de IL-10 e indutores de supressão imunológica comum nas mucosas intestinais (KELSALL et al., 2005; COOMBES e POWRIE, 2008; VILLADANGOS, 2008; BROWN et al., 2009). 

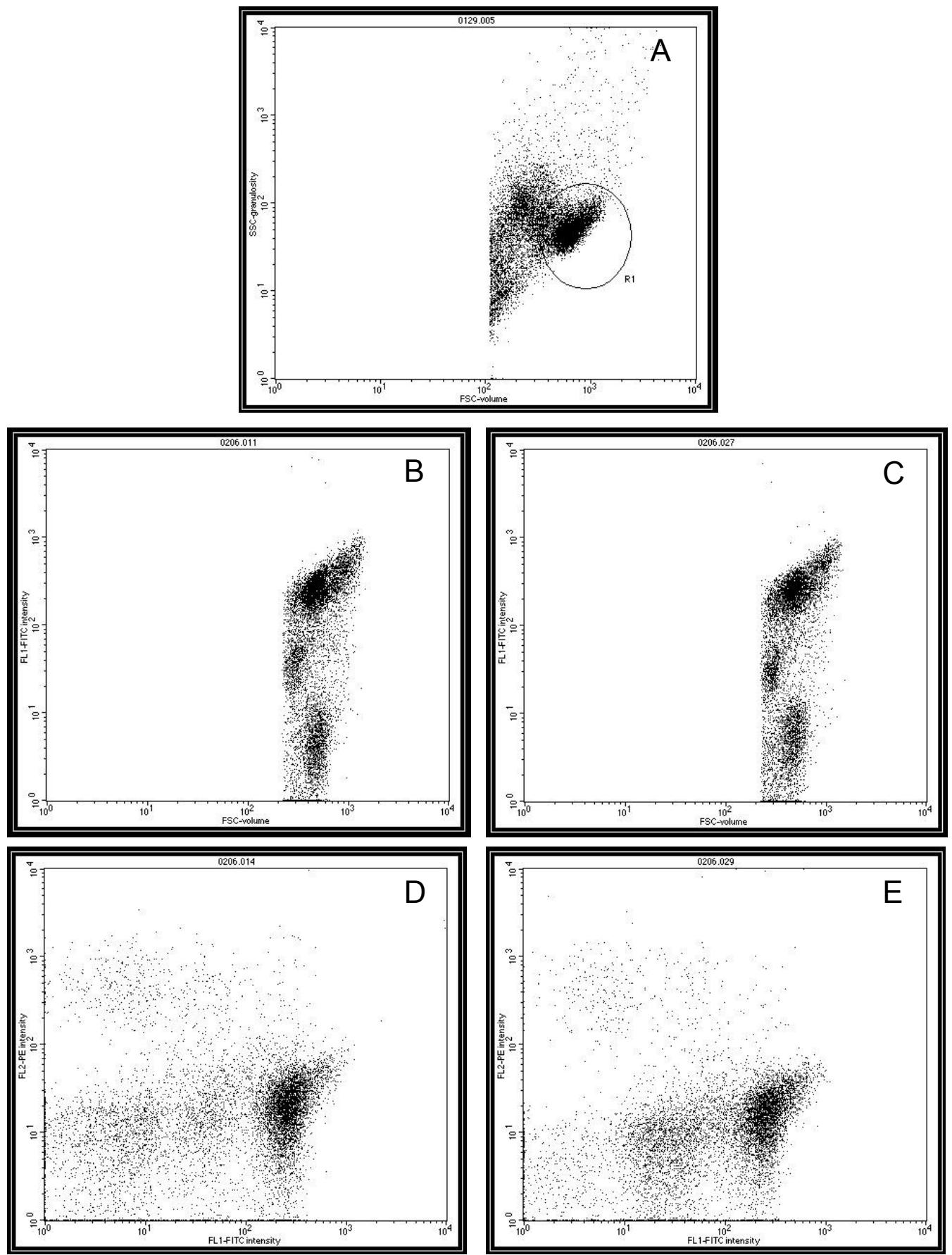

Figura 10- Figura representativa dos resultados obtidos por citometria de fluxo. Gráfico de pontos representativo da morfologia da população de células das placas de Peyer separadas por volume relativo (FSC-volume) e complexidade (SSC-granulosity) (A). Células de camundongos imunizados com HGG em PBS (B) e HGG em SBA-15 (C) após 7 dias da imunização, separadas por volume relativo (FSC-volume) e intensidade de marcação por CD45R/B220 FITC (FL1). Células de camundongos imunizados com HGG em PBS (D) e HGG em SBA15 (E) após 7 dias da imunização, separadas por intensidade de marcação por CD45R/B220 FITC (FL1) e CD8a PE (FL2). Resultados de dois experimentos independentes expressos em média $\pm \mathrm{SD} ; \mathrm{n}=3$ animais/grupo. 
A
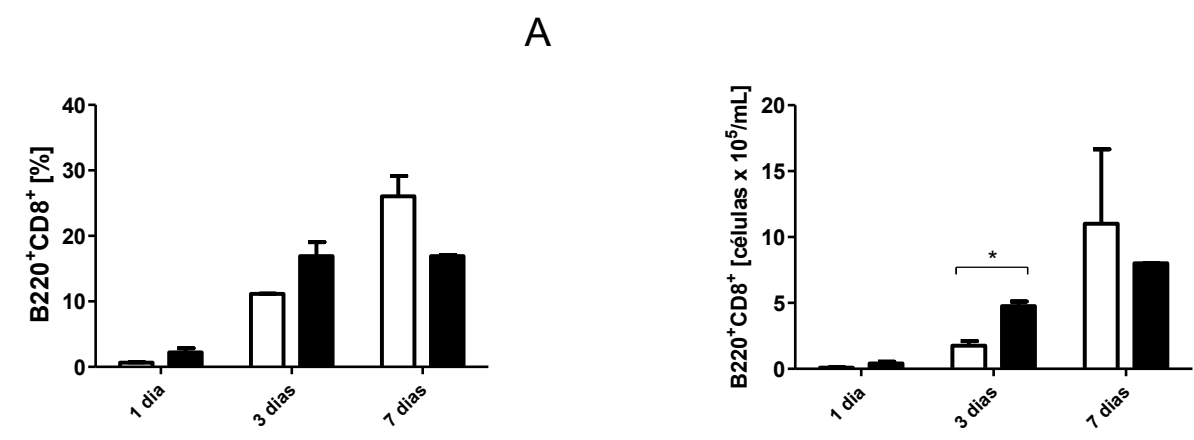

B

Figura 11- Distribuição fenotípica das células das placas de Peyer de camundongos BALB/c imunizados pela via oral. Camundongos imunizados com HGG ou HGG adsorvida em SBA-15. Freqüência (\%) de células $B 220^{+} \mathrm{CD} \mathrm{a}^{+}(\mathbf{A})$ e número total (células $\times 10^{5} / \mathrm{mL}$ ) de células $B 220^{+} \mathrm{CD} 8 \alpha^{+}(\mathrm{B})$ após 1 , 3 e 7 dias da imunização analisadas por citometria de fluxo. Resultados de dois experimentos independentes expressos em média $\pm S D ; n=3$ animais/grupo; grupo de animais imunizados com HGG foi utilizado como referência para análise do teste $t$ de Student, ${ }^{*} p<0,05$.

\subsubsection{Imunofenotipagem das células dos linfonodos mesentéricos}

\subsubsection{Imunização com gama globulina humana}

Análises por citometria de fluxo utilizando os marcadores de superfície celular CD4, CD8a, CD45R/B220, CD11b e CD11c foram realizadas para a avaliação da distribuição fenotípica das células dos linfonodos mesentéricos de camundongos BALB/c ( $n=3$ animais/grupo) imunizados pela via oral com HGG adsorvida ou não a SBA-15 após 1,3 e 7 dias. 
A
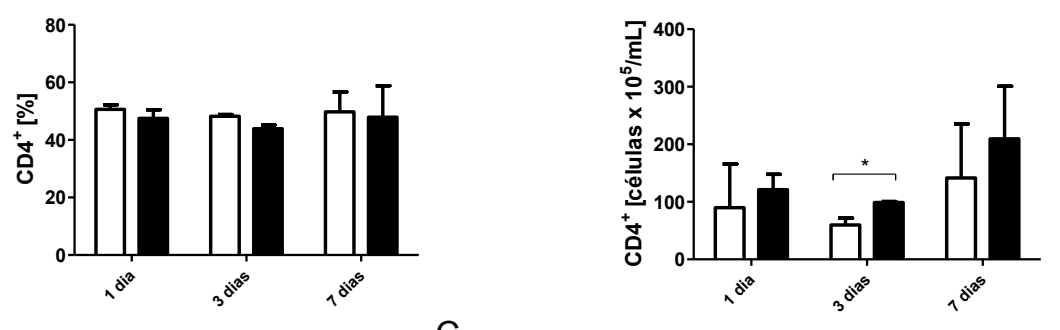

C
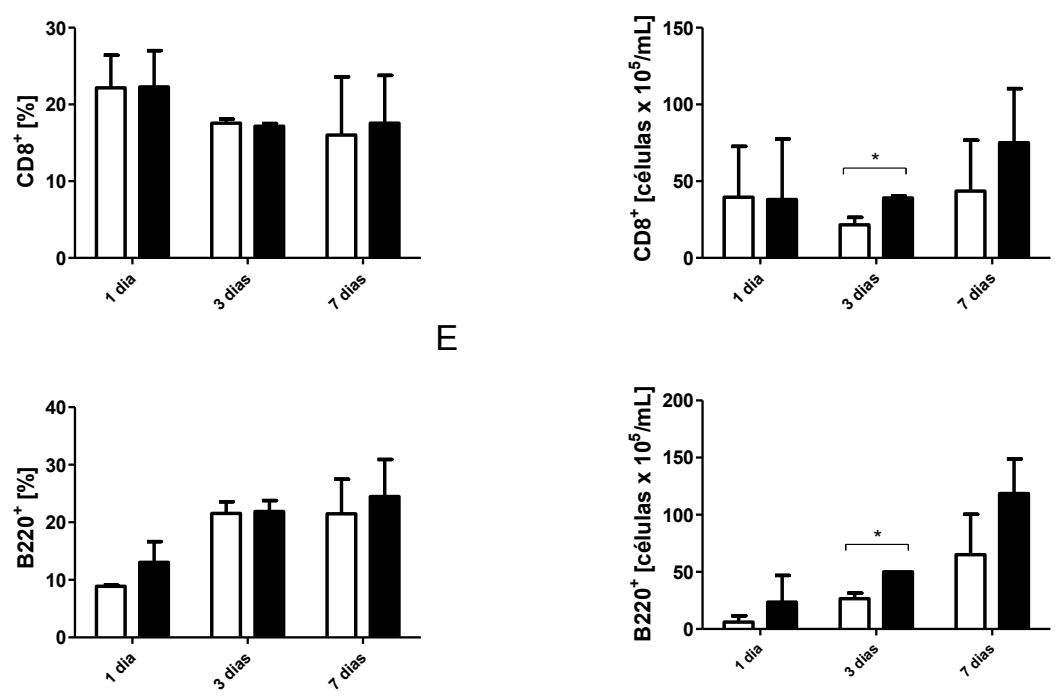

G

$\mathrm{H}$
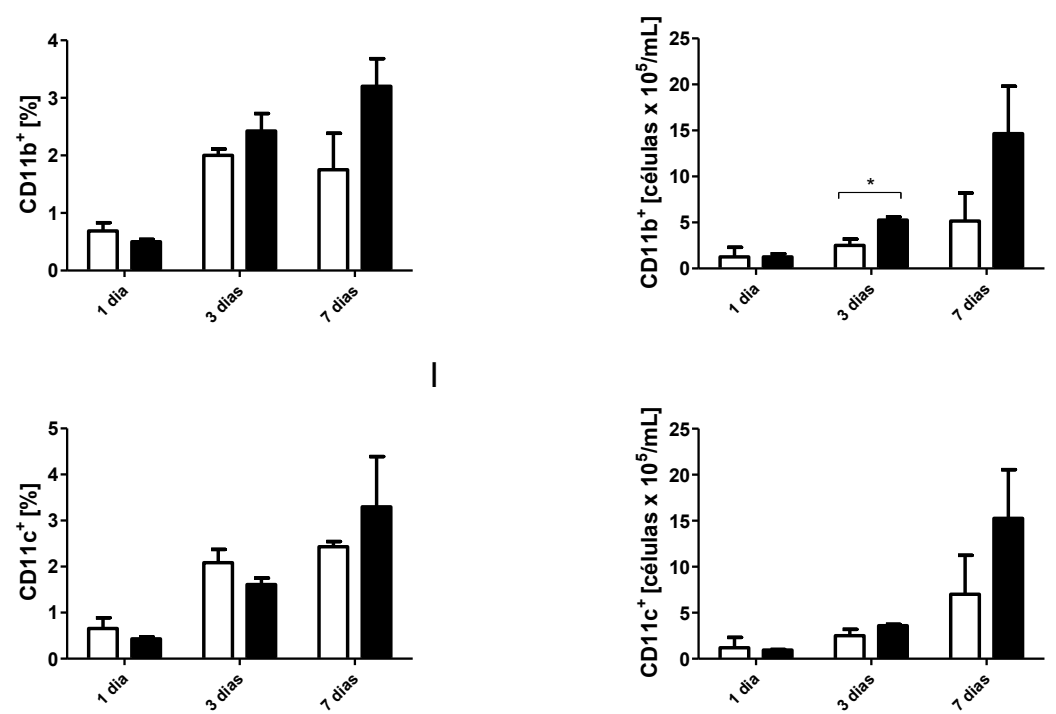

Figura 12- Distribuição fenotípica das células dos linfonodos mesentéricos de camundongos BALB/c imunizados pela via oral. Camundongos imunizados com HGG ou HGG adsorvida em SBA-15. Freqüência (\%) de células CD4 ${ }^{+}$ $(\mathbf{A}), \mathrm{CD}^{+}(\mathbf{C}), \mathrm{B}^{2} 20^{+}(\mathbf{E}), \mathrm{CD} 11 \mathrm{~b}^{+}(\mathbf{G})$ e $\mathrm{CD} 11 \mathrm{c}^{+}$(I) e número total (células $\mathrm{x}$

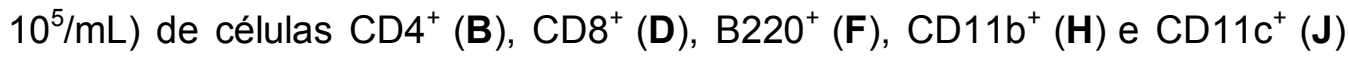
após 1,3 e 7 dias da imunização analisadas por citometria de fluxo. Resultados de dois experimentos independentes expressos em média $\pm S D ; n$ = 3 animais/grupo; grupo de animais imunizados com HGG foi utilizado como referência para análise do teste $t$ de Student, ${ }^{*} p<0,05$. 
Os resultados indicaram que as células $\mathrm{CD}^{+}$mantiveram sua freqüência constante durante os períodos analisados e não houve diferenças entre os grupos imunizados com HGG ou HGG adsorvida a SBA-15 (Figura 12A). Comparando o número total de células $\mathrm{CD}^{+}{ }^{+}$notou-se que os animais imunizados com HGG:SBA15 apresentaram número de células superior aos imunizados com HGG em PBS nos três períodos analisados e, após 3 dias da imunização, a diferença foi $\sim 40$ vezes maior nesse grupo, sugerindo a potencialização da resposta imune e da proliferação de linfócitos $T_{H}$ nos linfonodos (Figura 12B).

De modo semelhante, células $\mathrm{CD}^{+}$mantiveram sua freqüência constante até o $7^{\circ}$ dia da imunização (Figura 12C). Comparando-se o número total de células 3 dias após a imunização, observou-se aumento de $\sim 18$ vezes no grupo de animais imunizados com HGG em SBA-15 comparativamente ao grupo HGG. No $7^{\circ}$ dia, animais que receberam a HGG:SBA-15 apresentaram número maior de células $\mathrm{CD}^{+}$em relação aos animais imunizados com HGG (Figura 12D). Esses dados sugerem que a SBA-15 é capaz de induzir boa resposta de linfócitos $T$ citotóxicos após imunização pela via oral.

A análise de células $\mathrm{B}^{2} 20^{+}$indicou que houve aumento crescente na freqüência e número total dessas células nos linfonodos mesentéricos durante os períodos estudados, sugerindo proliferação celular devido ao desenvolvimento da resposta imune. No grupo imunizado com a HGG adsorvida a SBA-15, evidenciouse aumento na freqüência e no número total dessas células nos linfonodos até o $7^{\circ}$ dia da resposta imune (Figuras 12E e 12F). Sendo, no $3^{\circ}$ dia após imunização, o número total de células $B 220^{+}$do grupo HGG:SBA-15 cerca de 24 vezes maior relativamente ao grupo imunizado com HGG em PBS (Figura 12F). Mais uma vez, esses resultados comprovam a potencialização da resposta imune induzida pela sílica nanoestruturada SBA-15 na ativação e proliferação de linfócitos B. Como as placas de Peyer, os linfonodos mesentéricos são importantes sítios de produção de IgA protetora (CERUTTI, 2008). Os resultados da citometria de fluxo aliados aos elevados títulos de anticorpos específicos observados nos animais imunizados com HGG:SBA-15 reforçam o potencial adjuvante da sílica SBA-15 na imunização oral.

Células $\mathrm{CD}_{11} \mathrm{~b}^{+}$e $\mathrm{CD} 11 \mathrm{c}^{+}$aumentaram em número e freqüência durante os períodos analisados nos dois grupos de animais imunizados. Entretanto, foram superiores no grupo imunizado com o antígeno em sílica em relação ao grupo imunizado com o antígeno em PBS, especialmente após 3 dias (Figuras 12G, 12H, 
$12 \mathrm{l}$ e 12J). Nesse período, a análise referente ao número total de células $\mathrm{CD} 11 \mathrm{~b}^{+}$ indicou que o grupo HGG:SBA-15 tem $\sim 3$ vezes mais células que o grupo HGG (Figura 12H). Esses resultados sugerem a migração de fagócitos de outros tecidos do intestino, como lamina propria e placas de Peyer, para os linfonodos mesentéricos. Acredita-se ainda que a sílica tenha potencializado a captura de antígenos, provavelmente devido à proteção física conferida pela SBA-15, recrutando maior número de APC e potencializado o desenvolvimento da resposta de linfócitos B e T.

Como observado nas placas de Peyer, evidenciou-se uma subpopulação de células B220 ${ }^{\mathrm{LOW}}$ nos linfonodos mesentéricos de camundongos imunizados (Figura 13B e 13C). A avaliação da população de células dendríticas plasmocitóides $B 220^{+} \mathrm{CD} \mathrm{\alpha}^{+}(\mathrm{pDC})$ indicou aumento constante na freqüência e no número total dessas células do $1^{\circ}$ ao $7^{\circ}$ dia após a imunização (Figura 14A e 14B). Durante todo o período analisado, o grupo de animais imunizados com o antígeno em sílica apresentou maior quantidade de pDC relativamente ao grupo imunizado com HGG em PBS. Na Figura 13E essa população duplo marcada é claramente observada. 

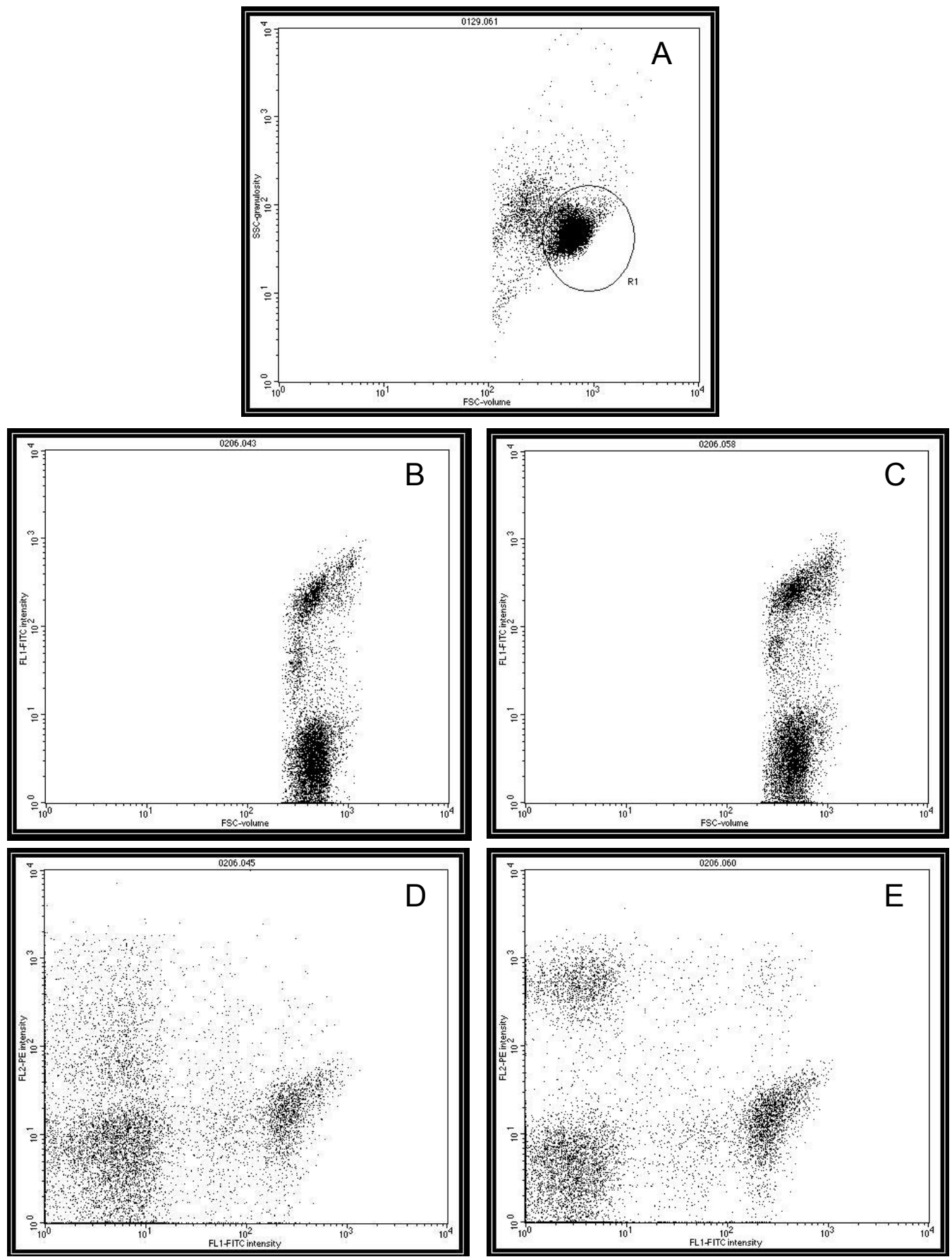

Figura 13- Figura representativa dos resultados obtidos por citometria de fluxo. Gráfico de pontos representativo da morfologia da população de células dos linfonodos mesentéricos separadas por volume relativo (FSC-volume) e complexidade (SSC-granulosity) (A). Células de camundongos imunizados com HGG em PBS (B) e HGG em SBA-15 (C) após 7 dias da imunização, separadas por volume relativo (FSC-volume) e intensidade de marcação por CD45R/B220 FITC (FL1). Células de camundongos imunizados com HGG em PBS (D) e HGG em SBA-15 (E) após 7 dias da imunização, separadas por intensidade de marcação por CD45R/B220 FITC (FL1) e CD8a PE (FL2). Resultados de dois experimentos independentes expressos em média $\pm S D ; n$ $=3$ animais/grupo. 

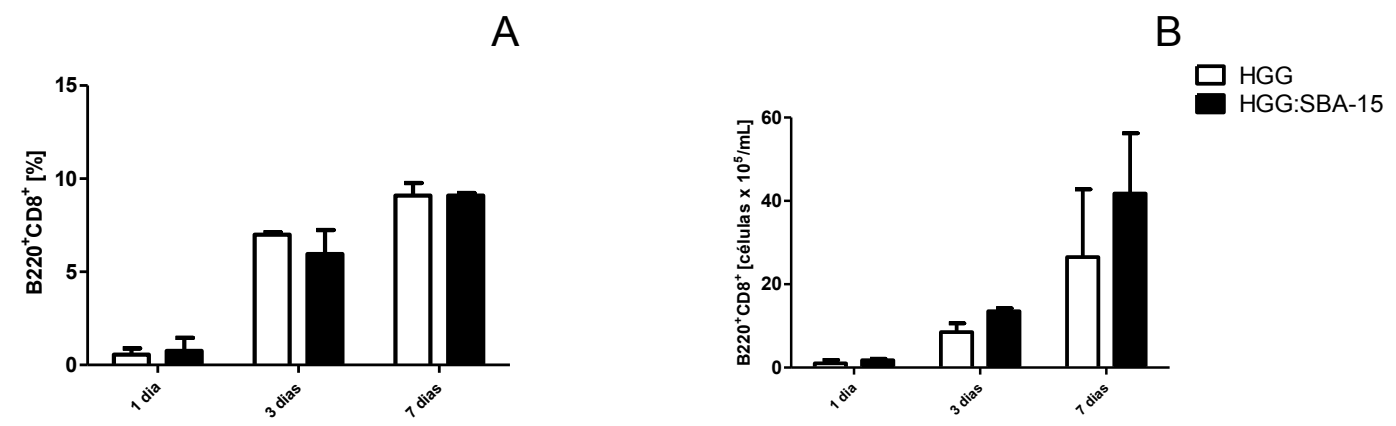

Figura 14- Distribuição fenotípica das células dos linfonodos mesentéricos de camundongos BALB/c imunizados pela via oral. Camundongos imunizados com HGG ou HGG adsorvida em SBA-15. Freqüência (\%) de células $B 220^{+} \mathrm{CD} \mathrm{a}^{+}(\mathbf{A})$ e número total (células $\times 10^{5} / \mathrm{mL}$ ) de células $\mathrm{B} 220^{+}$ $\mathrm{CD} \alpha^{+}(\mathbf{B})$ após 1, 3 e 7 dias da imunização analisadas por citometria de fluxo. Resultados de dois experimentos independentes expressos em média \pm $\mathrm{SD} ; \mathrm{n}=3$ animais/grupo; grupo de animais imunizados com HGG foi utilizado como referência para análise do teste $t$ de Student.

As pDC são produzidas e desenvolvem-se na medula óssea; dificilmente são detectadas nos tecidos periféricos e na linfa e acredita-se que essas células migrem, no caso de uma infecção, para os órgãos linfóides secundários através da corrente sanguínea. Essas células são capazes de reconhecer moléculas associadas à patógenos e secretar citocinas, sendo importantes componentes da defesa inata. Ainda, são capazes de ativar linfócitos $\mathrm{T} \mathrm{CD8}^{+}$e induzir a proliferação de linfócitos $\mathrm{T}$ $\mathrm{CD}^{+}$, além de participarem do desenvolvimento de linfócitos $\mathrm{T}$ reguladores (McPHERSON et al., 2006; COOMBES e POWRIE, 2008; VILLADANGOS, 2008).

\subsection{Reação inflamatória aguda induzida após administração subcutânea da sílica SBA-15}

\subsubsection{Perfil celular do exsudato inflamatório}

Demonstrada a eficiência da SBA-15 em potencializar a resposta de anticorpos em camundongos BALB/C e nos geneticamente selecionados para a baixa e alta produção de anticorpos ( $H_{I I I} ; L_{\text {III; }} H_{\text {IVA }}$ e $L_{\text {IVA }}$ ) imunizados por diferentes vias com antígenos variados, iniciaram-se estudos sobre o efeito local das aplicações dessa nanopartícula, sem adição de imunógenos, após indução do processo inflamatório subcutâneo. Analisou-se quantitativamente o influxo de células 
no exsudato inflamatório de camundongos $A I R_{M A X}$ e $A I R_{M I N} 24$ horas após a administração de SBA-15 (250 $\mathrm{\mu g}$ /animal) ou PBS $(0,2 \mathrm{~mL} / \mathrm{animal})$ pela via subcutânea. O recrutamento celular induzido pela sílica SBA-15 mostrou-se, aproximadamente, 3 vezes maior na linhagem $A_{I R} R_{M A X}$ e 2 vezes maior em $A I R_{M I N}$ quando comparado ao PBS (Tabela 4). O baixo potencial inflamatório dessa nanopartícula torna-se evidente quando os resultados obtidos são comparados aos dados descritos por Ribeiro et al. (2003), que utilizou como agente indutor de inflamação o Biogel P-100. Esse estudo indicou, após 24 horas, a presença de $75 \mathrm{x}$ $10^{6}$ células $/ \mathrm{mL}$ de exsudato inflamatório na linhagem AIR $_{\mathrm{MAX}}$, número 37 vezes maior ao obtido após a administração da SBA-15; enquanto animais AIR $_{\text {MIN }}$ apresentaram um número 23 vezes maior ao observado após tratamento com a sílica, aproximadamente $4,6 \times 10^{6}$ células $/ \mathrm{mL}$.

Tabela 4- Número total de células no exsudato inflamatório de camundongos AIR $_{\text {MAX }}$ e AIR $_{\text {MIN. }}$

\begin{tabular}{ccc}
\hline & SBA-15 & PBS \\
\hline AIR $_{\text {MAX }}$ & $2,0+0,5^{* *}$ & $0,7+0,4^{\text {ad }}$ \\
AIR $_{\text {MIN }}$ & $0,2+0,04$ & $0,1+0,07^{\text {a }}$ \\
\hline
\end{tabular}

Exsudato (células $\times 10^{6} / \mathrm{mL}$ ) analisado 24 horas após inoculação de PBS (0,2 $\left.\mu \mathrm{L} / a n i m a l\right)$ ou

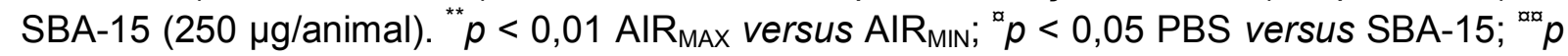
$<0,01$ PBS versus SBA-15 (teste $t$ de Student); $\mathrm{n}=4$ animais/grupo. Resultados de dois experimentos independentes expressos em média \pm SD.

Verificou-se também que não há relação direta entre a concentração de SBA-15 administrada e o número de células totais encontradas no exsudato inflamatório, após 24 a 96 horas do tratamento (Tabela 5). Após 24 horas, AIR MAX AIR $_{\text {MIN }}$ inoculados com $250 \mu \mathrm{g} /$ animal de SBA-15 apresentaram maior número de células no infiltrado em relação aos grupos que receberam doses maiores de SBA-15, provavelmente devido a diferenças individuais. Na linhagem AIR $\mathrm{MAX}_{\mathrm{M}}$ o total de células encontrado nos animais que receberam $250 \mu \mathrm{g} / a n i m a l$ de SBA-15 foi 3 vezes maior comparativamente ao grupo que recebeu $500 \mu \mathrm{g} / \mathrm{animal}$ e 5 vezes maior comparando-se ao grupo $2500 \mu \mathrm{g} /$ animal de SBA-15. Já na linhagem AIR $\mathrm{R}_{\mathrm{MIN}}$, o grupo $250 \mu \mathrm{g} / \mathrm{animal}$ de SBA-15 apresentou número de células 2 vezes maior em 
relação aos animais inoculados com 500 ou 2500 g/animal de sílica, conclui-se que a administração de altas doses dessa nanopartícula não induz maior recrutamento celular. No período de 72 horas, observou-se diferença de 10 vezes no número de células infiltradas em camundongos $A_{I R} R_{M I N}$ inoculados com alta dose de SBA-15

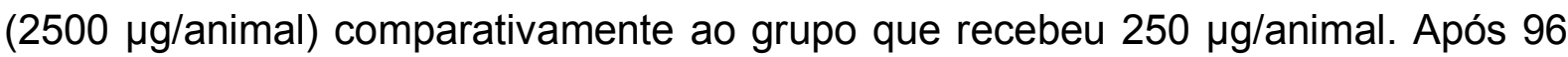
horas, o número total de células no infiltrado não apresentou diferenças significativas entre as doses e entre as linhagens.

Tabela 5- Número total de células no exsudato inflamatório de camundongos $\operatorname{AIR}_{\operatorname{MAX}} \mathrm{e}$ AIR $_{\text {MIN. }}$

\begin{tabular}{|c|c|c|c|c|}
\hline & & \multicolumn{3}{|c|}{ SBA-15 } \\
\hline & & 24 horas & 72 horas & 96 horas \\
\hline \multirow{3}{*}{ AIR $_{\text {MAX }}$} & $250 \mu \mathrm{g}$ & $2,0 \pm 0,5$ & $0,4 \pm 0,05$ & $0,1 \pm 0,02$ \\
\hline & $500 \mu \mathrm{g}$ & $0,6 \pm 0,3^{* *}$ & $0,4 \pm 0,3$ & $0,2 \pm 0,1$ \\
\hline & $2500 \mu \mathrm{g}$ & $0,4 \pm 0,2^{a a d}$ & $0,5 \pm 0,1$ & $0,1 \pm 0,02$ \\
\hline \multirow{3}{*}{ AlR $_{\text {MIN }}$} & $250 \mu \mathrm{g}$ & $0,2 \pm 0,04$ & $0,03 \pm 0,01$ & $0,02 \pm 0,007$ \\
\hline & $500 \mu \mathrm{g}$ & $0,09 \pm 0,08^{*}$ & $0,5 \pm 0,4$ & $0,1 \pm 0,04$ \\
\hline & $2500 \mu \mathrm{g}$ & $0,1 \pm 0,07^{a}$ & $0,3 \pm 0,1^{a x}$ & $0,03 \pm 0,007$ \\
\hline
\end{tabular}

Exsudato (células $\times 10^{6} / \mathrm{mL}$ ) analisado 24, 72 e 96 horas após inoculação de PBS $(0,2$ $\mu \mathrm{L} /$ animal) ou SBA-15 (250 a $2500 \mu \mathrm{g} / \mathrm{animal}) .{ }^{*} p<0,05250 \mu \mathrm{g}$ SBA-15 versus $500 \mu \mathrm{g}$ SBA-15; ${ }^{* *} p<0,01250 \mu \mathrm{g}$ SBA-15 versus $500 \mu \mathrm{g}$ SBA-15; ${ }^{a} p<0,05250 \mu \mathrm{g}$ SBA-15 versus $2500 \mu \mathrm{g} \mathrm{SBA}-15 ;{ }^{\text {ax }} p<0,01250 \mu \mathrm{g}$ SBA-15 versus $2500 \mu \mathrm{g} \mathrm{SBA-15;}{ }^{\text {axp }} p<0,001250 \mu \mathrm{g}$ SBA-15 versus $2500 \mu \mathrm{g}$ SBA-15 (teste $t$ de Student); $\mathrm{n}=4$ animais/grupo. Resultados de dois experimentos independentes expressos em média \pm SD.

De modo geral, nas primeiras 24 horas, observou-se aumento de 3 vezes no número de células no infiltrado de animais $A I R_{\operatorname{MAX}}$, linhagem geneticamente selecionada para alta resposta inflamatória aguda, comparativamente a

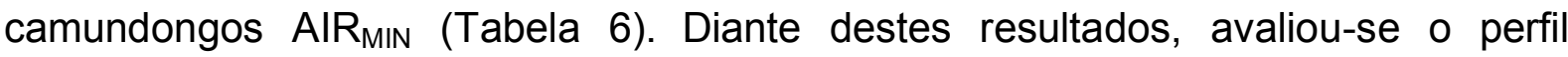
qualitativo das células infiltradas, destacando as diferenças entre as linhagens.

Tabela 6- Número total de células no exsudato inflamatório de camundongos $\operatorname{AIR}_{\operatorname{MAX}} \mathrm{e}$ $A I R_{\text {MIN. }}$ 


\begin{tabular}{cc}
\hline & SBA-15 \\
& 250 a $2500 \mu g /$ animal \\
\hline AIR $_{\text {MAX }}$ & $0,3 \pm 0,2^{*}$ \\
AIR $_{\text {MIN }}$ & $0,1 \pm 0,06$ \\
\hline
\end{tabular}

Exsudato (células $\times 10^{6} / \mathrm{mL}$ ) analisado 24 horas após inoculação de 250 a $2500 \mu \mathrm{g}$ de SBA-15 por animal. " $p<0,05$ AIR $_{\text {MAX versus AIR }}$ MIN (teste $t$ de Student); $\mathrm{n}=4$ animais/grupo. Resultados de dois experimentos independentes expressos em média \pm SD.

Um dia após a administração de SBA-15, observou-se predominância de neutrófilos em ambas as linhagens, o que corrobora os dados originais frente à inoculação de Biogel P-100; ainda observou-se que os animais $A_{\text {IRAX }}$ apresentaram maior número de neutrófilos no infiltrado do que os $A R_{M I N}$. Sabe-se que essas células são rapidamente recrutadas para o foco inflamatório, cerca de 15 a 45 minutos após lesão e/ou início de um processo infeccioso, e geram sinais quimiotáticos capazes de atrair monócitos e células dendríticas influenciando na diferenciação de macrófagos para um estado pró ou antiinflamatório. Em contrapartida, podem causar danos teciduais destruindo células nucleadas, anucleadas e células do tecido conectivo na tentativa de eliminar patógenos (NATHAN, 2006; HOGG et al., 2003). Após 72 horas, o perfil celular no local alterase, ocorrendo afluxo de macrófagos, sendo esses de grande importância na eficácia da resposta imune por participarem da apresentação antigênica (BILLACK, 2006).

A Figura 13 mostra a cinética da reação inflamatória das linhagens, 24, 72 e 96 horas após inoculação de $250 \mu \mathrm{g} /$ animal de SBA-15. Observou-se a presença majoritária de polimorfonucleares nas primeiras 24 horas e, passado este período, aumento no número de macrófagos. Na linhagem $A_{I R} R_{M A X}$, tem-se a presença de PMN por mais de 24 horas, e esse fato converge com uma das características fenotípicas desses animais, qual seja, a alta produção de neutrófilos e eosinófilos pela medula óssea quando de um estímulo inflamatório. Além disso, os neutrófilos dessa linhagem são menos propensos a apoptose espontânea, tendo assim maior

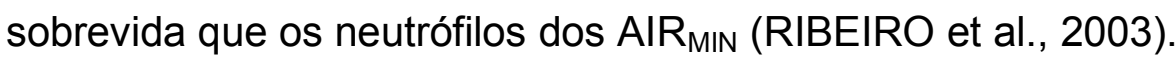


A

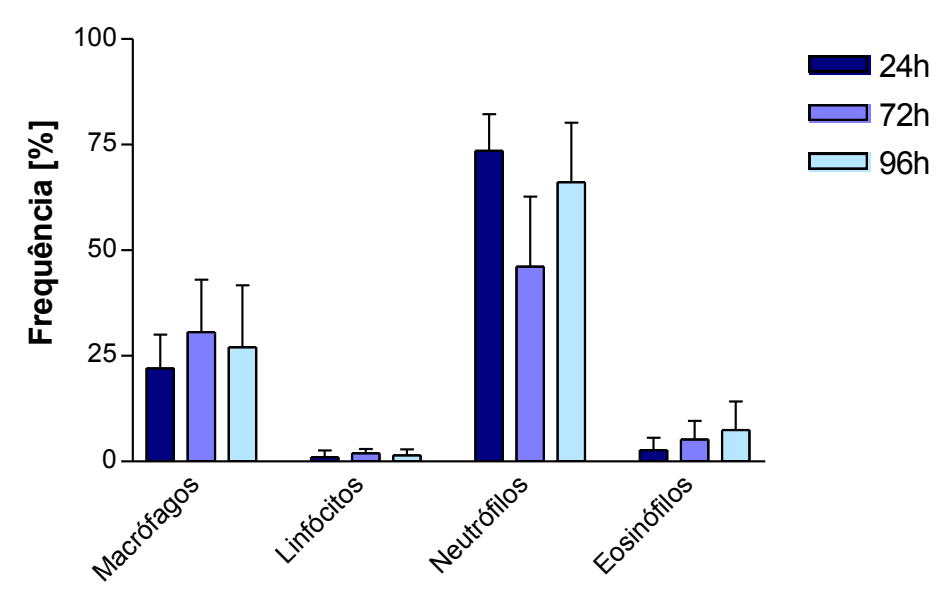

B

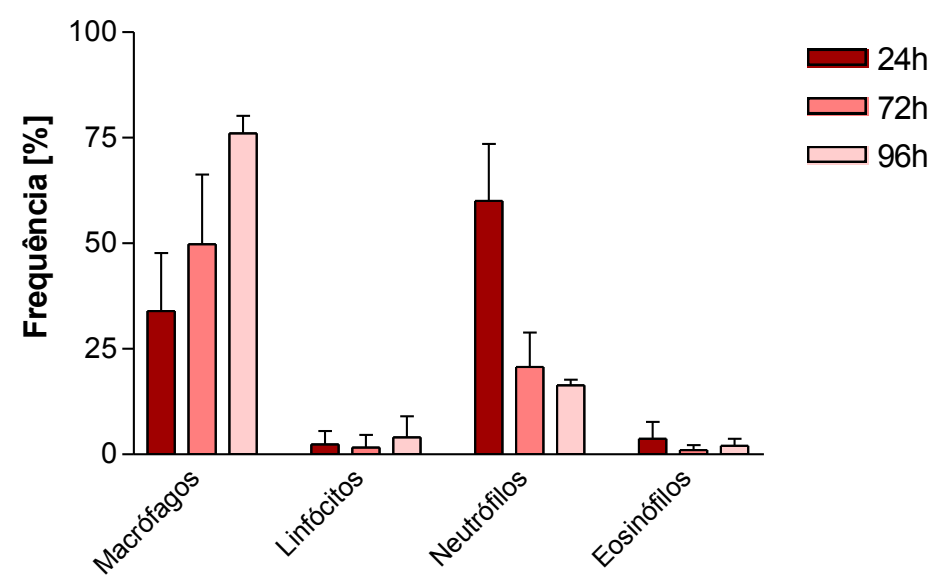

Figura 13- Porcentagem dos tipos celulares no exsudato inflamatório de camundongos $\operatorname{AIR}_{\text {MAX }}(A)$ e $\operatorname{AIR}_{\text {MIN }}$ (B). Exsudato analisado 24, 72 e 96 horas após inoculação de $250 \mu \mathrm{g} /$ animal SBA-15. Resultados de dois experimentos independentes expressos em média \pm SD.

A Figura 14 mostra células obtidas do exsudato inflamatório de animais $A_{I R} R_{M A X}$ e $A_{I R} R_{M I N}$ após 24 horas do tratamento com alta concentração de sílica (2500 $\mu \mathrm{g} /$ animal). É observado grande número de vacúolos nos macrófagos que seguem viáveis durante o período avaliado, o que indica possível estado de ativação. Sugere-se que a ativação dos macrófagos observada especialmente em $A R_{\text {MIN }}$, aliada aos dados apresentados na Figura 13 que mostram que a freqüência de macrófagos nessa linhagem permanece alta após 96 horas da inoculação de sílica, sejam indícios da potencialização da capacidade fagocítica dessas células induzida pela SBA-15 nessa linhagem. 


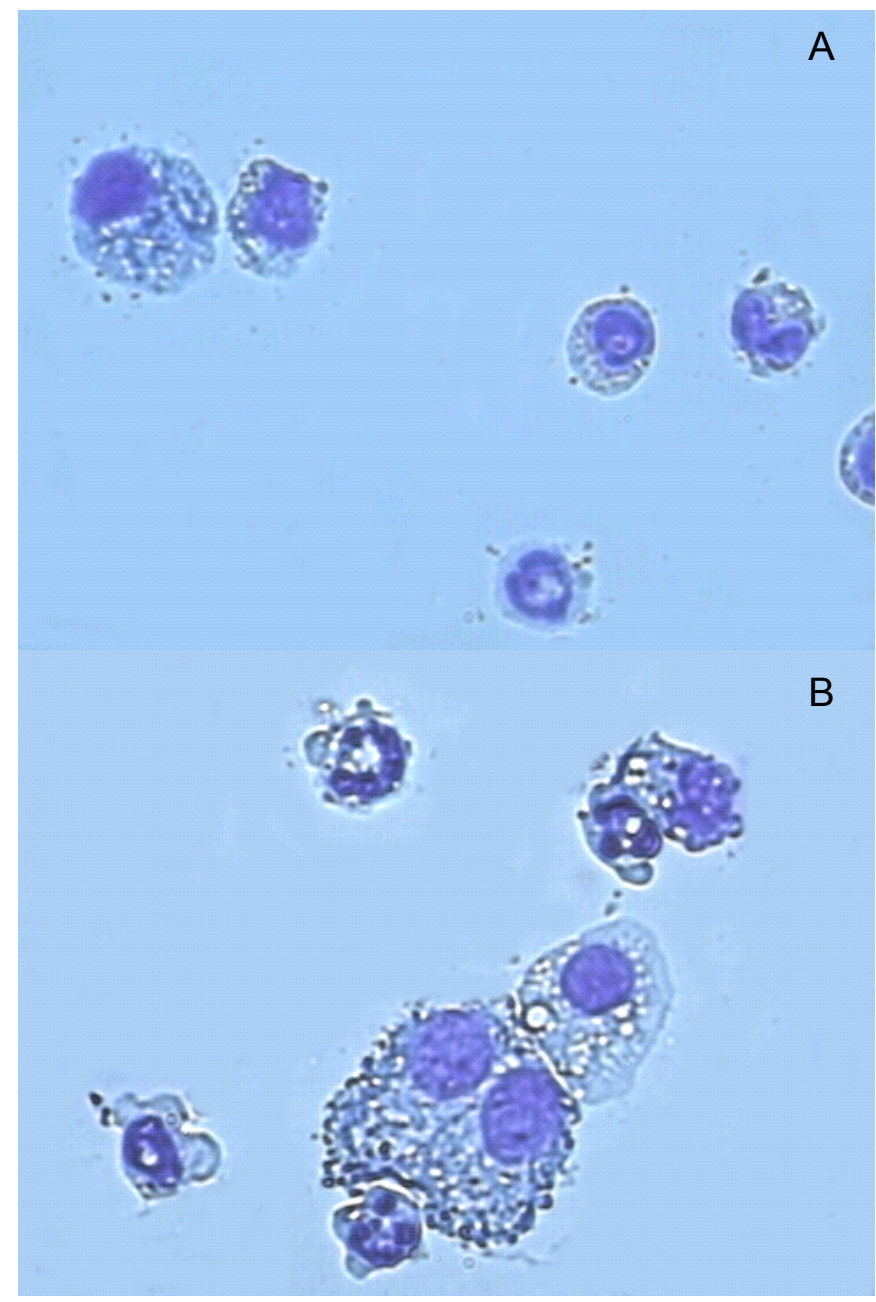

Figura 14- Macrófagos e neutrófilos de camundongos $\operatorname{AIR}_{\mathrm{MAX}}$ e $A I R_{\mathrm{MIN}}$. Células do exsudato inflamatório de camundongos $\operatorname{AIR}_{\mathrm{MAX}}(\mathrm{A})$ e $\mathrm{AIR}_{\mathrm{MIN}}(\mathrm{B})$. Exsudato avaliado 24 horas após tratamento com alta dose de sílica $(2500 \mu \mathrm{g} / \mathrm{animal})$. Microscopia de luz; aumento de 100x; corante Instant Prov (Newprov).

Estudos anteriores demonstraram que partículas de sílica coloidal fagocitadas por macrófagos promovem intoxicação ou prejudicam muitas de suas funções catabólicas (VOGEL et al., 1982; GENNARI et al., 1987). À época, todos os resultados apontavam para o bloqueio dessas funções, fato que facilitaria a atuação de outras células do sistema imune, explicando a modulação positiva da resposta humoral efetiva de camundongos constitutivamente maus respondedores. Há descrições de que sílicas coloidais agravam processos patológicos em doenças autoimunes (BROWN et al., 2004; BROWN et al., 2003; PFAU et al., 2004) e, ainda, induzem inflamação crônica de pulmão em roedores (MIGGLIACCIO et al., 2005; KANJ et al., 2005; KAEWAMATAWONG et al., 2005). Um estudo in vitro demonstrou 
que um tipo de sílica cristalina estimula a produção de IL-1 $\beta$, TNF- $\alpha$ e NO por macrófagos, induzindo a apoptose dessas células (SRIVASTAVA et al., 2002).

Estudos sobre o efeito in vitro da SBA-15 sobre macrófagos derivados de precursores da medula óssea das linhagens de camundongos geneticamente selecionadas para baixa resposta de anticorpos ( $L_{\text {III }}$ e $L_{\text {IVA }}$ ) e heterogêneos Swiss foram realizados. Após 96 horas da administração de diferentes doses de SBA-15 (20 a $1000 \mu \mathrm{g} / \mathrm{mL}$ ), macrófagos mantiveram sua capacidade fagocítica e não se observaram alterações morfológicas e/ou morte celular. Estes estudos confirmaram a não toxicidade da SBA-15 para esses tipos celulares, favorecendo a utilização desta nanopartícula como adjuvante (CARVALHO, 2009, manuscrito em preparação). ${ }^{1}$

\subsection{Análise comparativa da resposta inflamatória aguda induzida pela SBA-15 e pelo hidróxido de alumínio - $\mathrm{Al}(\mathrm{OH})_{3}$}

Os principais adjuvantes licenciados para uso em humanos, considerados seguros e eficientes, são o hidróxido e fosfato de alumínio. Esses adjuvantes atuam na indução de inflamação local, com o estímulo à produção de citocinas, quimiocinas e moléculas de adesão além do recrutamento rápido, nas primeiras 6 horas após a administração intramuscular ou subcutânea, de neutrófilos, eosinófilos e células inflamatórias $\mathrm{CD} 11 \mathrm{~b}^{+} \mathrm{F} 4 / 80^{+}$, monócitos precursores de células dendríticas (HOGENESCH et al., 2002; LAMBRECHT et al., 2009; MOSCA et al., 2008; KOOL et al., 2008).

O estudo comparativo entre a resposta inflamatória aguda induzida após administração subcutânea de SBA-15 ou $\mathrm{Al}(\mathrm{OH})_{3}$ em camundongos das linhagens $A_{I R} R_{M A X}$ e $A I R_{\text {MIN }}$ indicou que os mesmos tipos celulares são recrutados para o foco inflamatório, mantendo-se o padrão previamente observado para SBA-15 (Figuras 13 e 15), com predomínio de neutrófilos nas primeiras 24 horas (Figura 15). Estudos recentes demonstraram que, 12 a 24 horas após a inoculação de $\mathrm{Al}(\mathrm{OH})_{3}$, há recrutamento de neutrófilos e eosinófilos para o foco inflamatório, confirmando nossos resultados (LAMBRECHT et al., 2009; MOSCA et al., 2008; KOOL et al., 2008).

${ }^{1}$ CARVALHO, L.V. São Paulo, 2009. 


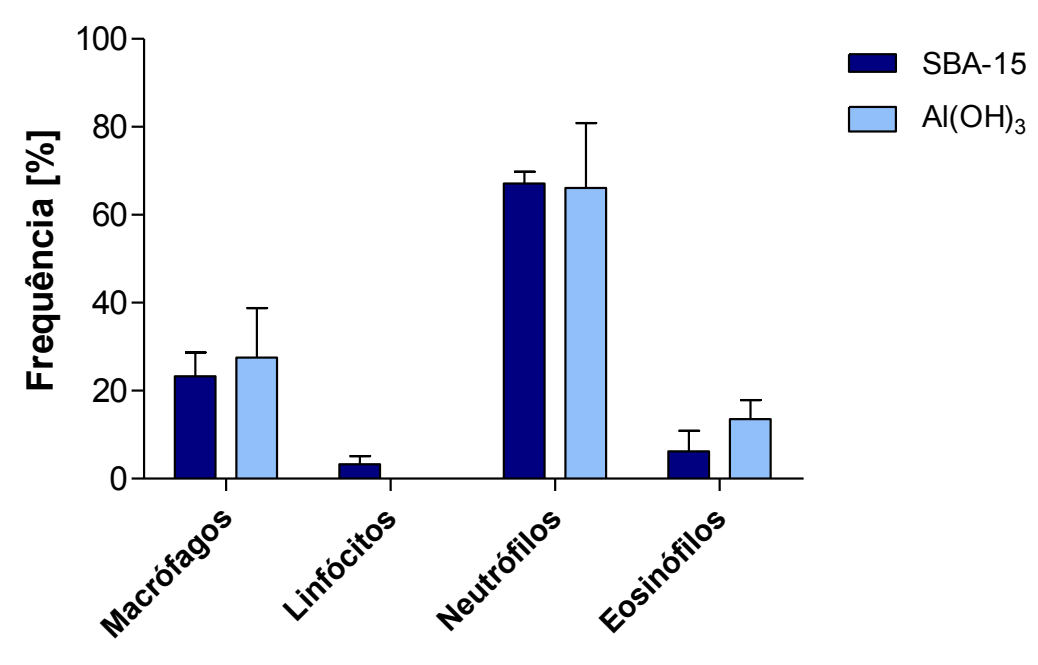

B

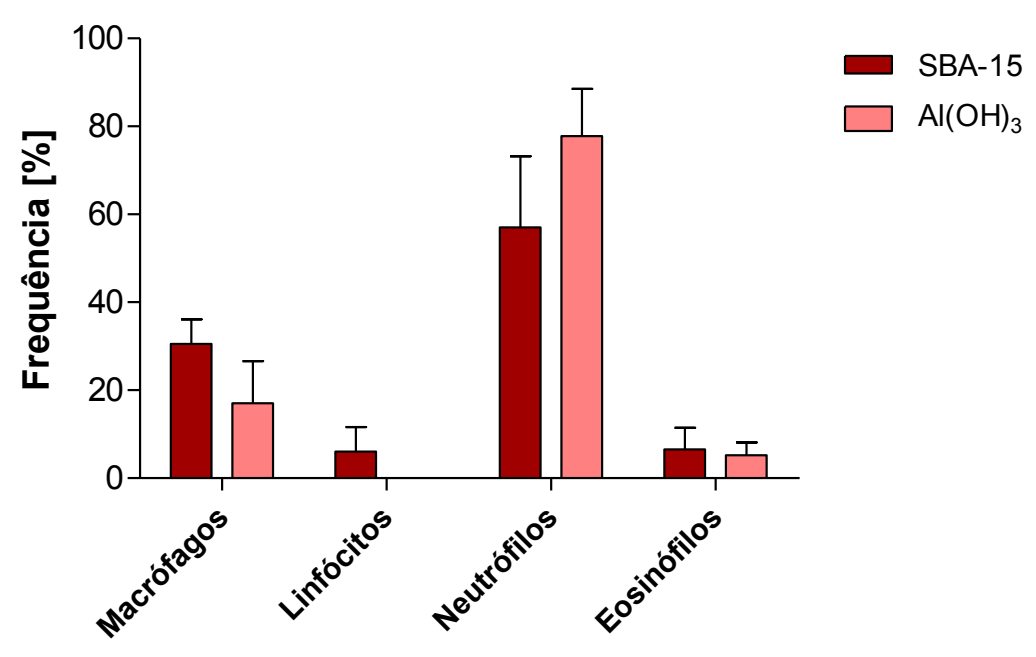

Figura 15- Tipos celulares e dosagem de proteínas no exsudato inflamatório de camundongos das linhagens AIR $_{\text {MAX }}$ e AIR MIN $_{\text {tratados com SBA-15 ou }}$ $\mathrm{Al}(\mathrm{OH})_{3}$. Porcentagem dos tipos celulares encontrados no exsudato inflamatório 24 horas após inoculação de SBA-15 ou Al(OH $)_{3}(250 \mu \mathrm{g} / a n i m a l)$ em animais $\operatorname{AIR}_{\text {MAX }}(A)$ e $A I R_{M I N}(B) . n=4$ animais/grupo. Resultados de dois experimentos independentes expressos em média \pm SD (células $\times 10^{6} / \mathrm{mL}$ ).

Em relação aos tipos celulares, observou-se discreto aumento no número de macrófagos após a inoculação de SBA-15 nos camundongos $A_{I R} R_{M I N}$ quando comparado ao tratamento com $\mathrm{Al}(\mathrm{OH})_{3}$ (Figura 15B). Como visto nas Figuras 13 e 14, $\mathrm{AIR}_{\mathrm{MIN}}$ tendem a recrutar esses tipos celulares de maneira eficiente, fato que parece 
favorável ao desenvolvimento da resposta imune a partir do tratamento com SBA-15 por potencializar a apresentação antigênica em indivíduos maus respondedores.

A análise do número absoluto de células recuperadas do exsudato inflamatório desses camundongos mostrou que os AIR $_{\mathrm{MAX}}$ tratados com SBA-15 apresentaram cerca de 2 vezes mais células comparativamente aos animais que receberam $\mathrm{Al}(\mathrm{OH})_{3}$. Na Tabela 7, evidencia-se, em contrapartida, que camundongos $\mathrm{AIR}_{\mathrm{MIN}}$ tratados com SBA-15 mostraram número reduzido de células em cerca de 1,5 vezes comparativamente aos tratados com $\mathrm{Al}(\mathrm{OH})_{3}$.

Tabela 7- Número absoluto de células no exsudato inflamatório de camundongos AIR $_{\text {MAX }}$ e AIR MIN. $_{\text {. }}$

\begin{tabular}{ccc}
\hline & SBA-15 & Al(OH) $)_{3}$ \\
\hline AIR $_{\text {MAX }}$ & $2,0 \pm 0,5^{* * *}$ & $0,7 \pm 0,2$ \\
AIR $_{\text {MIN }}$ & $0,2 \pm 0,04^{* *}$ & $0,3 \pm 0,1$ \\
\hline
\end{tabular}

Exsudato (células $\times 106 / \mathrm{mL}$ ) inflamatório analisado 24 horas após inoculação de SBA-15 $(250 \mu \mathrm{g} /$ animal $)$ ou $\mathrm{Al}(\mathrm{OH})_{3}\left(250 \mu \mathrm{g} /\right.$ animal). ${ }^{* *} p<0,01 ;{ }^{* * *} p<0,001 \mathrm{SBA}-15$ versus $\mathrm{Al}(\mathrm{OH})_{3}$ (teste $t$ de Student); $\mathrm{n}=4$ animais/grupo; Resultados de dois experimentos independentes expressos em média \pm SD.

Deve-se ressaltar que, ao longo dos nossos estudos, não se observou a formação de eritemas ou lesões nos animais tratados com SBA-15, efeitos colaterais comumente observados após administração de $\mathrm{Al}(\mathrm{OH})_{3}$ durante processos de imunização. A formação de lesões ou granuloma nesses casos pode ocorrer devido ao efeito citotóxico do $\mathrm{Al}(\mathrm{OH})_{3}$ sobre macrófagos e células dendríticas que, quando acumulado no local da injeção, pode levar à ativação indireta e constante dessas APC através do estímulo a produção de fatores endógenos e TNF-a (BREWER, 2006).

Em relação ao processo inflamatório, esses dados em conjunto indicam a segurança e eficácia da sílica SBA-15 como possível adjuvante em processos de imunização. 


\section{CONCLUSÕES}

A análise dos resultados obtidos a partir das imunizações pela via oral com a vacina contra Hepatite A e gama globulina humana adsorvidas em SBA-15 comprovam a aplicabilidade dessa sílica como suporte para antígenos e evidenciam sua eficácia enquanto adjuvante de mucosas.

Os níveis aumentados de anticorpos específicos séricos e secretores das classes IgA e IgG indicam que a SBA-15 é eficiente na indução de resposta de anticorpos sem polarizar a resposta imunológica à determinada classe de linfócitos $\mathrm{T}_{\mathrm{H}}$. Corroborado pelos títulos de anticorpos protetores, os elevados números de linfócitos T e, especialmente de linfócitos B observados nas placas de Peyer e linfonodos mesentéricos de camundongos imunizados com os antígenos em sílica indicam que houve proliferação de células imunocompetentes e a potencialização da resposta imune após o uso dessa nanopartícula como adjuvante. Ainda, a SBA-15 mostrou-se eficiente no recrutamento de macrófagos e células dendríticas após imunização oral e inoculação subcutânea.

$O$ uso das linhagens $A_{I R}$ MAX e AIR ${ }_{M I N}$, geneticamente selecionadas, possibilitou o melhor entendimento do processo inflamatório local induzido após administração subcutânea da SBA-15. Conclui-se que, em ambas as linhagens, a sílica mostrou-se não-tóxica e com baixo potencial inflamatório, não evidenciando reações locais como eritema e/ou formação de nódulos subcutâneos. 


\section{REFERÊNCIAS BIBLIOGRÁFICAS}

AFZALI, B.; LOMBARDI, G.; LECHLER, R.I.; LORD, G.M. The role of T helper 17 (Th17) and regulatory $T$ cells (Treg) in human organ transplantation and autoimmune disease. Clin. Exp. Immunol., v. 148, p. 32-36, 2007.

AKDIS, C.A.; OZDEMIR, C. AKDIS, M. T regulatory cells and their counterparts: masters of immune regulation. Clin. Exp. Allergy, v. 39, p. 626-639, 2009.

ARAÚJO, L.M.M.; RIBEIRO, O.G.; SIQUEIRA, M.; De FRANCO, M.; STAROBINAS, N.; MASSA, S. Innate resistence to infections by intracellular bactéria differs in mice selected for maximal or minimal acute inflammatory response. Eur. J. Immunol., v. 28, p. 2913-2920, 1998.

BANCHEREAU, J.; STEINMAN, R.M. Dendritic cells and the control of immunity. Nature, v. 392, p. 245-252, 1998.

BILLACK, B. Macrophage activation: role of toll-like receptors, nitric oxide, and nuclear factor kappa B. Am. J. Pharm. Educ., v. 70, p. 102, 2006.

BIOZZI, G.; MOUTON, D.; SANT'ANNA, O.A.; PASSOS, H.C.; GENNARI, M.; REIS, M.H.; FERREIRA, V.C.; HEUMANN, A.M.; BOUTHILLIER, Y.; IBAÑEZ, O.M.; STIFFEL, C.; SIQUEIRA, M. Genetics of immunoresponsiveness to natural antigens in the mouse. Curr. Top. Microbiol. Immunol., v. 85, p. 31-98, 1979.

BIOZZI, G.; RIBEIRO, O.G.; SARAN, A.; ARAÚJO, M.L.; MARIA, D.A.; De FRANCO, M.; CABRERA, W.K.; SANT'ANNA, O.A.; MASSA, S.; COVELLI, V.; MOUTON, D.; NEVEU, T.; SIQUEIRA, M.; IBAÑEZ, O.M. Effect of genetic modification of acute inflammatory responsiveness on tumorigenesis in the mouse. Carcinogenesis, v. 19, p. 337-46, 1998.

BORREGO, A.; PETERS, L.C.; JENSEN, J.R.; RIBEIRO, O.G.; CABRERA, W.H.K.; STAROBINAS, N.; SEMAN, M.; IBAÑEZ, O.M.; De FRANCO, M. Genetic determinants of acute inflammation regulat Salmonella infection and modulate Slc11a1 gene (Formerly Nramp1) effects in selected mouse lines. Microbes Infect., v. 8, p. 2766-2771, 2006.

\section{* De acordo com:}

ASSOCIAÇÃO BRASILEIRA DE NORMAS TÉCNICAS. NBR 6023: Informação e documentação: referências: elaboração. Rio de Janeiro, 2002. 
BOVIER, P.A. Epaxal: a virosomal vaccine to prevent hepatitis A infection. Expert. Rev. Vaccines, v. 7, p. 1141-1150, 2008.

BRANDTZAEG, P.; JOHANSEN, F.E. Mucosal B cells: phenotypic characteristics, transcriptional regulation, and homing properties. Immunol. Rev., v. 206, p. 32-63, 2005

BRANDTZAEG, P.; BAEKKEVOLD, E.S.; FARSTAD, I.N.; JAHNSEN, F.L.; JOHANSEN, F.E.; NILSEN, E.M.; YAMANAKA, T. Regional specialization in the mucosal immune system: what happens in the microcompartments? Immunol. Today, v. 20, p. 141-151, 1999.

BREWER, J.M. (How) do aluminium adjuvants work? Immunol. Lett., v. 102, p. 510, 2006.

BROWN, J.M.; ARCHER, A.J.; PFAU, J.C.; HOLIAN, A. Silica accelerated systemic autoimmune disease in lupu-prone New Zealand mixed mice. Clin. Exp. Immunol., v. 131, P.415-421, 2003.

BROWN, J.M.; PFAU, J.C.; HOLIAN, A. Immunoglobulin and lymphocyte responses following silica exposure in New Zealand mixed mice. Inhal. Toxicol., v. 16, p. 133139, 2004.

BROWN, K.N.; WIJEWARDANA, V.; LIU, X.; BARRATT-BOYES, S.M. Rapid influx and death of plasmacytoid dendritic cells in lymph nodes mediate depletion in Acute Simian Immunodeficiency Virus Infection. Plos Pathog., v. 5, 2009. doi: e1000413.

CARNEIRO, A.S.; RIBEIRO, O.G.; De FRANCO, M.; CABRERA, W.H.; VORRARO, F.; SIQUEIRA, M.; IBAÑEZ, O.M.; STAROBINAS, N. Local inflammatory reaction induced by Bothrops jararaca venom differs in mice selected for acute inflammatory response. Toxicon, v. 40, p. 1571-1579, 2002.

CARVALHO, L.V. Estudo experimental do efeito adjuvante da sílica nanoestruturada SBA-15. Dissertação (Mestrado) - Universidade de São Paulo, São Paulo, 2007.

CERUTTI, A. The regulation of IgA class switching. Nat. Immunol., v. 8, p.421-434, 2008. 
CERUTTI, A.; RESCIGNO, M. The biology of intestinal immunoglobulin A responses. Immunity, v. 28, p. 740-750, 2008.

COOMBES, J.L.; POWRIE, F. Dendritic cells in intestinal immune regulation. Nat. Immunol., v. 8, p.435-446, 2008.

COFFMAN, R.L. Origins of the $\mathrm{T}(\mathrm{H}) 1-\mathrm{T}(\mathrm{H}) 2$ model: a personal perspective. Nat. Immunol., v. 7, p.539-541, 2006.

COX, J.C.; COULTER, A.R. Adjuvants--a classification and review of their modes of action. Vaccine, v. 15, p. 248-56, 1997.

DA SILVA, A.C.; DE SOUZA, K.W.; MACHADO, R.C.; DA SILVA, M.F.; SANT'ANNA, O. A. Genetics of immunological tolerance: I. Bidirectional selective breeding of mice for oral tolerance. Res. Immunol., v. 149, p. 151-161, 1998.

DANDEKAR, S.; SMIT-MCBRIDE, Z.; MATTAPALLIL, J.J.; MCCHESNEY, M.; FERRICK, D. Gastrointestinal $T$ lymphocytes retain high potential for cytokine responses but have severe CD4 T-cell depletion at all stages of Simian Immunodeficiency Virus Infection compared to peripheral lymphocytes. J. Virol., v. 72, p. 6646-6656, 1998.

EDELMANN, R.; TACKET, C.O. Adjuvants. Int. Rev. Immunol., v. 7, p. 51-66, 1990.

ENGVALL, E.; PERLMAN, P. Enzyme-linked immunosorbent assay (ELISA): quantitative assay of immunoglobulin G. Immunochemistry, v. 8, p. 871-874, 1971.

FARIA, A.M.; WEINER, H.L. Oral tolerance. Immunol. Rev., v. 206, p. 232-259, 2005.

FAUVE, R.M.; JUSFORGUES, H.; HEVIN, B. Maintenance of granuloma macrophages in serum-free medium. J. Immunol. Methods, v. 64, p.345-51, 1983.

FOGED, C.; SUNDBLAD, A.; HOVGAARD, L. Targeting vaccines to dendritic cells. Pharm. Res., v. 19, p. 229-238, 2002. 
GENNARI, M.; BOUTHILLIER, Y.; IBAÑEZ, O.M.; FERREIRA, V.C.; MEVEL, J.C.; REIS, M.H.; PIATTI, R.M.; RIBEIRO, O.G.; BOIZZI, G. Effect of silica on the genectic regulation of antibody responsiveness. Ann. Inst. Pasteur Immunol., v. 138, p.359-370, 1987.

GOTO, N.; KATO, H.; MAEYAMA, J.; SHIBANO, M.; SAITO, T.; YAMAGUCHI, J.; YOSHIHARA, S. Local tissue irritating effects and adjuvant activities of calcium phosphate and aluminium hydroxide with different physical properties. Vaccine, v. 15, p. 1364-1371, 1997.

HOGENESCH, $\mathrm{H}$. Mechanisms of stimulation of the immune response by aluminum adjuvants. Vaccine, v. 20, p. 34-39, 2002.

HOGG, N.; HENDERSON, R.B.; HOBBS, J.A.; MATHIES, M. Rapid recruitment of inflammatory monocytes is independent of neutrophil migration. Blood, v. 1, p. 32835, 2003.

HOGQUIST, K.A.; MORAN, A.E. Treg cells meet their limit. Nat. Immunol., v. 10, p 565-566, 2009.

IBAÑEZ, O.M.; STIFFEL, C.; RIBEIRO, O.G.; CABRERA, W.H.K.; MASSA, S.; De FRANCO, M.; SANT'ANNA, A.O.; DECREUSEFOND, C.; MOUTON, D.; SIQUEIRA, M.; BIOZZI, G. Genetics of nonspecific immunity: I. Bidirectional selective breeding of lines of mice endowed with maximal or minimal inflammatory responsiveness. Eur. J. Immunol., v. 2, p. 2555-2563, 1992.

IWASAKI, A.; KELSALL, B.L. Mucosal immunity and inflammation. I. Mucosal dendritic cells: their specialized role in initiating T cell responses. Am J Physiol., v. 276, p.1074-1078, 2008.

JANSEN, T.; HOFMANS, M.P.M.; THEELEN, M.J.G.; SCHIJNS, V.E.J.N. Structureactivity relations of water-in-oil vaccine formulations and induced antigen-specific antibody responses. Vaccine, v. 23, p. 1053-1060, 2005.

JEPSON, M.A.; CLARK, M.; FOSTER, N.; MASON, C.M., BENNETT, M.K.; SIMMONS, N.L.; HIRST, B.H. Targeting to intestinal M cells. J. Anat., v. 189, p. 507$516,1996$.

JONSDOTTIR, I.; HANNESDOTTIR, S.G.; OLAFSDOTTIR, T.A.; GIUDICE, G.D. Adjuvants LT-K63 and CPG enhance the activation of dendritic cells in neonatal mice. Scand. J. Immunol., v. 68, p. 469-475, 2008. 
KAEWAMATAWONG, T.; KAWAMURA, N.; OKAJIMA, M.; SAWADA, M.; MORITA, T.; SHIMADA, A. Acute pulmonary toxicity caused by exposure to colloidal sílica: particle size dependent pathological changes in mice. Toxicol. Pathol., v. 33, p. 743749, 2005.

KANJ, R.S.; KANG, J.L.; CASTRANOVA, V. Measurement of the release of inflammatory mediators from rat alveolar macrophages and alveolar type II cells following lipopolysaccharide or silica exposure: a comparative study. J. Toxicol. Environ. Health Part A, v. 68, p. 185-207, 2005.

KELSALL, B.L.; JOHANSSON, C. Phenotype and function of intestinal dendritic cells. Semin. Immunol., v. 17, p. 284-294, 2005.

KOOL, M.; SOULLIE, T.; VAN NIMWEGEN, M.; WILLART, M.A.; MUSKENS, F.; JUNG, S.; HOOGSTEDEN, H.C.; HAMMAD, H.; LAMBRECHT, B.N. Alum adjuvant boosts adaptative immunity by inducing uric acid and activating inflammatory dendritic cells. J. Exp. Med., v. 205, p. 869-882, 2008.

KRAEHENBUHL, J.P.; CORBETT, M. Immunology. Keeping the gut microflora at bay. Science, v. 303, p.1624-1625, 2004.

KRESGE, C.T.; LEONOWIEZ, M.E.; ROTH, W.J.; VARTULI, J.C.; BECK, J.S. Ordered mesoporous molecular sieves synthesized by a liquid-crystal template mechanism. Nature, v. 359, p. 710-712, 1992.

LAMBRECHT, B.N.; KOOL, M.; WILLART, A.M.M.; HAMMAD, H. Mechanism of action of clinically approved adjuvants. Curr. Opin. Immunol., v. 21, p. 1-7, 2009.

LAROCCA, R.; MARGUTI, I.; CABRERA, W.; RIBEIRO, O.G.; RIZZO, L.V.; DE MORAIS, L.V. Maximal inflammatory response benefits syngeneic skin graft acceptance. Inflamm. Res., v. 57, p. 171-177, 2008.

LEBIEN, T.W.; TEDDER, T.F. B lymphocytes: how they develop and function. Blood, v. 112 , p. $1570-1580,2008$.

MARIA, D.A.; MANETTI, G.; GALBIATI, F.; RIBEIRO, O.G.; De FRANCO, M.; STAROBINAS, N.; SIQUEIRA, M.; DRAGANI, T.A.; IBAÑEZ, O.M. Pulmonary adenoma susceptibility 1 (Pas1) lócus affects inflammatory response. Oncogene, v. 22, p. 426-432, 2003. 
MARTIN, A.; LEMON, S.M. Hepatitis A virus: from discovery to vaccines. Hepatology, v. 43, p. 164-172, 2006. Suppl. 1.

MATOS, J.R.; MERCURI, L.P.; KRUK, M.; JARONIEC, M. Toward the Synthesis of Extra-Large-Pore MCM-41 Analogues. Chem. Mater., v. 13, p. 1726-1731, 2001.

MELNICK, J.L. Properties and classification of hepatitis A virus. Vaccine, v. 10, Suppl 1: S24-26, 1992.

MERCURI, L.P.; CARVALHO, L.V.; LIMA, F.A.; QUAYLE, C.; FANTINI, M.C.A.; TANAKA, G.S.; CABRERA, W.H.; FURTADO, M.F.D.; TAMBOURGI, D.V.; MATOS, J.R.; JARONIEC, M.; SANT'ANNA, A.O. Ordered mesoporous to sílica SBA-15: A new effective adjuvant to induce antibody response. Small, v. 2, p. 254-256, 2006.

MIGLIACCIO, C.T.; HAMILTON, R.F. Jr.; HOLIAN, A. Increase in a distinct pulmonary macrophage subset possessing an antigen-presenting cell phenotype and in vitro APC activity following silica exposure. Toxicol. Appl. Pharmacol., v. 205, p. 168-176, 2005.

MORA, J.R.; IWATA, M.; EKSTEEN, B.; SONG, S.Y.; JUNT, T.; SENMAN, B.; OTIPOBY, K.L.; YOKOTA, A.; TAKEUCHI, H.; RICCIARDI-CASTAGNOLI, P.; RAJEWSKY, K.; ADAMS, D.H.; VON ANDRIAN, U.H. Generation of gut-homing IgAsecreting B cells by intestinal dendritic cells. Science, v. 314, p. 1157-1160, 2006.

MOSCA, F.; TRITTO, E.; MUZZI, A.; MONACI, E.; BAGNOLI, F.; IAVARONE, C.; O'HAGAN, D.; RAPPUOLI, R.; De GREGORIO, E. Molecular and cellular signatures of human vaccine adjuvants. Proc. Natl. Acad. Sci. USA, v. 30, p. 10501-10506, 2008.

NATHAN, C. Neutrophils and immunity: challenges and opportunities. Nat. Rev. Immunol., v. 3, p. 173-182, 2006.

OUKKA, M. Th17 cells in immunity and autoimmunity. Ann. Rheum. Dis., v. 67, p. 26-29, 2008. Suppl. 3.

PHALIPON, A.; CARDONA, A.; KRAEHENBUHL, J.P.; EDELMAN, L.; SANSONETTI, P.J.; CORTHÉSY, B. Secretory component: a new role in secretory IgA-mediated immune exclusion in vivo. Immunity, v. 17, p. 107-115, 2002.

PETERS, L.C.; JENSEN, J.R.; BORREGO, A.; CABRERA, W.H.K.; BAKER, N.; STAROBINAS, N.; RIBEIRO, O.G.; IBAÑEZ, O.M.; De FRANCO, M. Slc11a1 (Formerly Nramp1) gene modulates both acute inflammatory reactions and pristaneinduced arthritis in mice. Genes Immun., v. 8, p. 51-56, 2007. 
PINOY; LE MOIGNIC. Les vaccins en emulsion dans les corps gras ou "lipo-vaccins", C. R. Soc. Biol., v. 79, p. 201-203, 1916.

PFAU, J.C.; BROWN, J.M.; HOLIAN, A. Silica-exposed mice generate autoantibodies to apoptotic cells. Toxicology, v. 195, p. 167-176, 2004.

RIBEIRO, O.G. Controle genético da inflamação. Dissertação (Mestrado) - Escola Paulista de Medicina, São Paulo, 1994.

RIBEIRO, O.G.; CABRERA, W.H.K.; MARIA, D.A.; De FRANCO, M.; MASSA, S.; et al. Genetic selection for high acute inflammatory response confers resistence to lung carcinogenesis in the mouse. Lung Res., v. 31, p. 105-116, 2005.

RIBEIRO, O.G.; MARIA, D.A.; ADRIOUCH, S.; PECHBERTY, S.; CABRERA, W.H.K.; MORISSET, J.; IBAÑEZ, O.M.; SEMAN, M. Convergent alteration of granulopoieses, chemotactic activity and neutrophil apoptosis during mouse selection for high acute inflammatory response. J. Leukoc. Biol., v. 74, p. 497-506, 2003.

ROMAGNANI, S. Regulation of T cell response. Clin. Exp. Allergy, v. 36, p. 13571366, 2006.

SHALABY, W.S. Development of oral vaccines to stimulate mucosal and systemic immunity: barriers and novel strategies. Clin. Immunol. Immunopathol., v.74, p. 127-134,1995.

SCHIJNS, V.E.J.N.; DEGEN, W.G.J. Vaccine immunopotentiators of the future. Clin. Pharmacol. Ther., v. 82, p. 750-5, 2007.

SMITH, P.L.; YEH, P.Y.; ELLENS, H. Physiological considerations in the design of particulate dosage forms for oral vaccine delivery. Adv. Drug Deliv. Rev., v. 34, p. 123-133, 1998.

SRIVASTAVA, K.D.; ROM, W.N.; JAGIRDAR, J.; YIE, T.A.; GORDON, T.; TCHOUWONG, K.M. Crucial role of interleukin-1 $\beta$ and nitric oxide synthase in silica-induced inflammation and apoptosis in mice. Am. J. Respir. Crit. Med., v. 165, p. 527-533, 2002.

STIFFEL, C.; IBAÑEZ, O.M.; RIBEIRO, O.G.; DECREUSEFOND, C.; MOUTON, D.; SIQUEIRA, M.; BIOZZI, G. Genetics of acute inflammation: inflammatory reactions in inbred lines of mice and in their interline crosses. Exp. Clin. Immunogenet., v. 7, p. 221-233, 1990. 
VASQUEZ-BRAVO, Y.L.A.R. Aspecto da resposta inflamatória aguda em linhagens de camundongos com reatividade máxima (AIR $R_{M A X}$ ) e mínima (AIR $\left.R_{M I N}\right)$ obtidas por seleção genética bidirecional. Tese (Doutorado) - Universidade de São Paulo, São Paulo, 1996.

VIGAR, N.D.; CABRERA, W.H.K.; ARAÚJO, L.M.M.; RIBEIRO, O.G.; OGATA, T.R.P.; SIQUEIRA, M. Pristane-induced arthritis in mice selected for maximal or minimal acute inflammatory reaction. Eur. J. Immunol., v. 30, p. 431-437, 2000.

VILLADANGOS, J.A.; YOUNG, L. Antigen-presentation properties of plasmacytoid dendritic cells. Immunity, v. 29, p. 352-361, 2008.

VOGEL, S.N.; ENGLISH, K.E.; O’BRIEN, A.D. Silica enhancement of murine endotoxin sensitivity. Infect. Immun., v. 38, p.681-685, 1982.

VOS, Q.; LEES, A.; WU, Z.Q.; SNAPPER, C.M.; MOND, J.J. B-cell activation by Tcell-independent type 2 antigens as an integral part of the humoral immune response to pathogenic microorganisms. Immunol. Rev., v. 176, p. 154-170, 2000.

YANG, H.; COOMBS, N.; OZIN, G.A. Morphogenesis of shapes and surface patterns in mesoporous silica. Nature, v. 386, p. 692-695, 1997.

YI, H.J.; LEE, C.G.; KWON, H.K.; SO, J.S.; SAHOO, A.; HWANG, J.S.; JASH, A.; HWANG, K.C.; IM, S.H. Defect TCR-CD3ろ signaling mediates T cell hyporesponsiveness in mesenteric lymph node. Mol. Immunol., V. 45, p. 3748-3755, 2008.

MACPHERSON, GG.; YRLID, U.; CEROVIC, V.; MILLING, S.; JENKINS, C.D.; ZHANG, J.; CROCKER, P.R.; KLAVINSKIS, L.S. Plasmacytoid dendritic cells do not migrate in intestinal or hepatic lymph. J. Immunol., v. 177, p. 6115-6121, 2006.

ZHAO, D.; FENG, J.; HUO, Q.; MELOSH, N.; FREDRICKSON, G.H.; CHMELKA, B.F.; STUCKY, G.D. Triblock copolymer syntheses of mesoporous silica with periodic 50 to 300 angstrom pores. Science, v. 279, p. 548-552, 1998. 